MARIA ELISABETH MACHADO PINTO E SILVA

\title{
HIDROLISADO DE CARNE COMO RECURSO DIETÉTICO
}

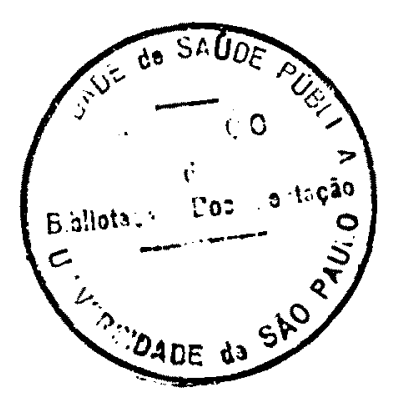

Tese apresentada à Faculdade de Saúde Pública da Universidade de São Paulo, Departamento de Nutrição, para obtenção do título de Doutor em Saúde Pública.

Orientadora: Profa. Dra. Rosa Nilda Mazzilli

\section{SÃO PAULO}

1995 


\section{DEDICATÓRIA}

A meus pais pelos ensinamentos da vida

A vocês José Otávio, Cláudio, Bruno e Vitor razão da minha vida 


\section{AGRADECIMENTOS}

À Professora Doutora Rosa Nilda Mazzilli pela paciência e dedicação na elaboração deste trabalho.

À todos do Departamento de Nutrição, não citarei nomes para não faltar nenhum, que acompanharam com maior ou menor intensidade as diversas etapas do trabalho, dando forças e incentivando para o êxito da conclusão deste.

Aos funcionários em geral da Faculdade de Saude Pública que em diferentes momentos colaboraram com cabines para degustação, fotos, obtenção de material bibliográfico de difícil acesso, correções nas referências e como provadores.

À Área Técnica do Mercado Institucional da Sadia Comercial pelo fornecimento dos produtos e a equipe de análise do Laboratório Central da Frigobrás.

Às hoje nutricionistas Regina HarumiYamaji e Raquel Franzini pela colaboração no desenvolvimento da paret prática do trabalho e análise sensorial.

Aos membros da banca examinadora que contribuiram para 0 aperfeiçoamento do trabalho, dando sugestões valiosas, os Professora Associada Dorina Barbieri, Professora Doutora Maria Aparecida Azevedo P. Silva, Professora Doutora Elizabeth Aparecida Ferraz da Silva Torres, Professora Doutora Maria de Fátima Nunes Marucci, Professora Doutora Sonia Buongermino de Souza. 


\section{RESUMO}

O trabalho teve como objetivo estudar a aplicação de hidrolisado de carne (bovina, peru e frango) em preparaçōes usualmente utilizadas em nossa alimentação e com padrão de aceitabilidade. Para obtenção do hidrolisado foi utilizada a carne com o suco de abacaxi "in natura" como fonte de bromelina (enzima proteolítica). Esse processo é de baixo custo e sua aplicação em preparações fáceis, contribui para variações nos cardápios com produto de valor nutricional maior, independentemente da classe sócioeconômica. Foram eleitas 4 preparaçōes: sopa de beterraba, bolinho de batata, mousse de uva e vitamina de legumes e frutas. Todas as receitas foram desenvolvidas no Laboratório de Técnica Dietética da Faculdade de Saúde Pública / USP com recursos similares aos domésticos, para sua garantia à adequada orientação dietoterápica.

Para a conclusão das preparaçōes realizaram pelo menos 6 sessões laboratórios, quando o produto final obtido foi semelhante ao da receita padrão. A maior dificuldade em adaptar o hidrolisado foi com a carne bovina por ter coloração mais escura, sendo necessário portanto utilizar alimentos com cores mais fortes. A aceitabilidade foi verificada através da análise sensorial pelo método da escala hedônica, utilizando degustadores não treinados, funcionários, professores e alunos da Faculdade de Saúde Pública/USP. Para o experimento, utilizou-se o delineamento estatistico através da análise de variância e teste de Tuckey. Os hidrolisados foram analisados quanto à sua composição centesimal: umidade, gordura, proteina. O valor nutritivo das preparaçōes foi calculado antes e após a utilização do hidrolisado para comparação, utilizando o programa NUTRI-HNT.

Os hidrolisados de carne apresentaram leve sabor residual, devendo ser mascarado nas diferentes preparações. $O$ de bovino teve a coloração marrom, influenciando no produto final. $O$ resultado da análise sensorial mostrou que as preparações com hidrolisado de carne, de peru e de frango foram as de melhor aceitação. A substituição de liquidos pelos hidrolisados de carne requer seleção adequada de receitas e seus ingredientes e o conhecimento das caracteristicas sensoriais e fisico quimicas é de fundamental importância na obtenção de produto satisfatório.

A utilização do hidrolisado de carne na preparação melhora o seu valor nutricional em proteinas, alguns minerais e vitaminas, em especial naquelas que usualmente não se acrescenta a carne (bolinho, mousse e vitamina). A forma em que se encontra a proteina no hidrolisado é vantajosa para o aproveitamento pelo organismo, podendo ser utilizado com as mais diversas finalidades, desde dietas especiais, suplementação alimentar, e até em alimentação enteral, com um dos seus constituintes.

O hidrolisado de carne, assim apresentou aplicabilidade nas preparações selecionadas, através de sua aceitação, facilidade de sua obtenção com custos reduzidos e recursos disponiveis para a população em geral. 


\section{SUMMARY}

The objective of this study was to use hydrolysed meat (beef, turkey, or chicken) in the way usually prepared and accepted in the country. The meat was hydrolysed with bromelin (proteolytic enzyme) from pineapple's fresh juice. This process is cheap and easy to prepare, producing a large variety of foods of high nutritional value; being acessible to people from all socio economic levells. Four preparations of foods were selected as the best: beetroot soup, fried potato cake, grape musse and legumes and fruits shake. All recipes were developed at the Tecnical Dietetic Laboratory of the Public Health Faculty/USP in similar domestic conditions, to garantee an adequate dietetic orientation.

The preparations were performed six times in the laboratory until a product similar with the standard was achieved. Hydrolysed beef was the most difficult to prepare because of the dark color, demanding the use of foods with strong colours. The acceptability was tested by sensorial analysis, using hedonic scale, by not trained tasters (workers, teachers and students of the Public Health Faculty/USP). The hydrolysed meats were analysed according to their composition, humidity, fat and protein. The nutritional value of the preparations were calculated before and after the utilization of the preparation for comparation, utilising the programme NUTRI-HNT. The statistical analysis was performed by the analysis of variance and Tukey test.

The hydrolysed meat showed a mild residual flavour, that needed to be hidden in the preparation. The beef had brown coloration, influencing the final product. Sensory analysis showed that hydrolised turkey and chicken had better acceptability. The use of hydrolysate meat in the substitution of liquids demand adequate selection of recipes and ingredients. The knowledge of the sensorial and physico chemical caracteristics of the foods is essential to obtain a good product.

The use of hydrolysed meat in the preparation of foods, improved the nutritional value in proteins, vitamins and minerals, especially in those products that did not contain meat (cake, musse and shake). The protein in the hydrolysed meat improves its utilization by the organism. It may be used with great variability; in special diets, food supplementation, and enteral diets

Hydrolysed meat presents a good applicability in selected preparations, showing good acceptability, facility to obtain at a low cost and availability by the population in general. 


\section{ÍNDICE}

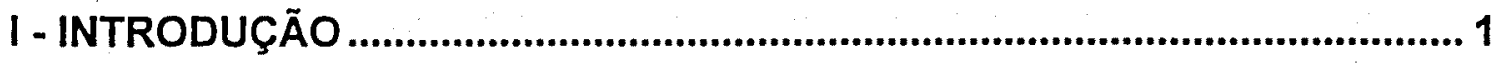

II - OBJETIVOS................................................................................................... 13

III - MATERIAL E MÉTODOS ............................................................................. 14

1 - Material .............................................................................................. 14

1.1 - Carnes ...................................................................................... 14

1.2 - Enzimas proteoliticas ................................................................... 14

1.3 - Receitas selecionadas..................................................................... 14

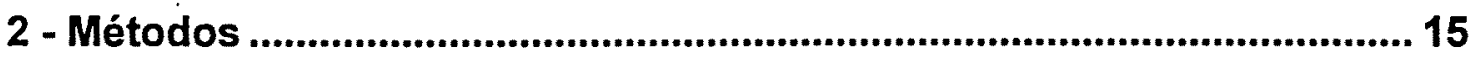

2.1 - Hidrólise da carne......................................................................... 15

2 . 2 - Composição centesimal dos hidrolisados.......................................... 16

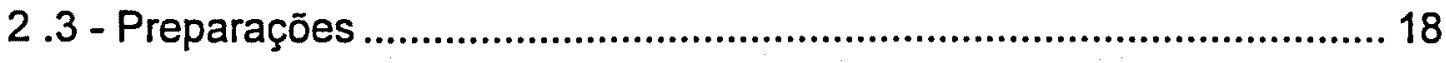

2.4 - Valor nutritivo das preparações ......................................................... 19

2.5 - Análise sensorial .............................................................................. 19

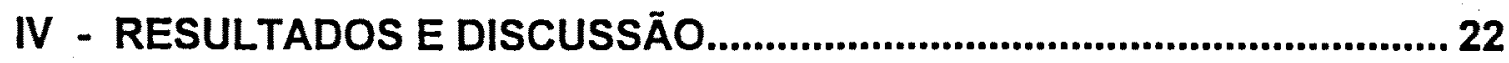

1 - COMPOSIÇĀO CENTESIMAL DAS CARNES IN NATURA E SEUS HIDROLISADOS............................................................................................... 22

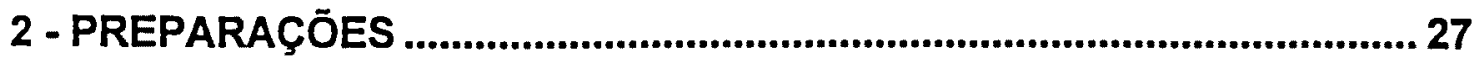

3 - VALOR NUTRITIVO DAS PREPARAÇÕES........................................... 29 


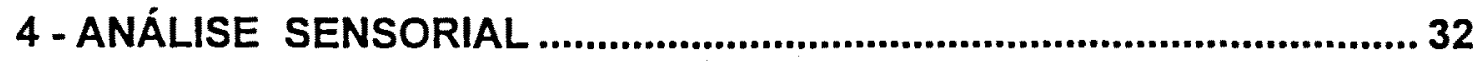

4.1 - Preparações com hidrolisado de carne bovina : .................................. 33

4.2 - Preparações com hidrolisado de carne de peru :................................. 38

4.3 - Preparações com hidrolisado de frango ............................................ 42

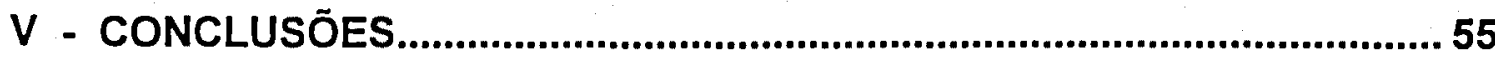

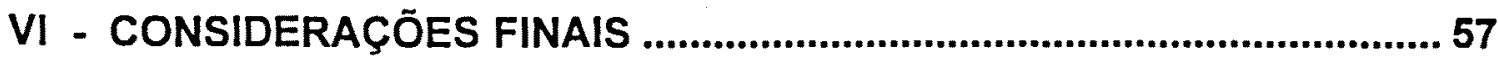

VII - REFERÊNCIAS BIBLIOGRÁFICAS ..................................................58

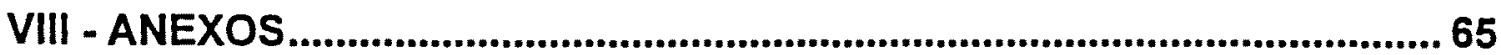


I - INTRODUÇÃO 


\section{I-INTRODUCEÃO}

A alimentação é essencial para qualquer ser vivo e é específica conforme a fase de seu crescimento, desenvolvimento e manutenção, quando a necessidade de reposição ou complementação alimentar pode exigir um nutriente especial, por diferentes causas.

Todo alimento ingerido, para ser aproveitado pelo organismo, passa por um processo de digestão, ou seja, a sua transformação em frações menores, por meios mecânicos e químicos, e depois assimilação e eliminação(5, 12).

As ações mecânicas, integrantes da digestão, consistem na trituração dos alimentos, na propagação dos produtos da digestão, nos resíduos e na excreção ao longo do tubo digestivo. As caracteristicas de motilidade das paredes digestivas são, em grande parte, função da natureza dos músculos, produzindo o movimento chamado peristaltismo. É um processo involuntário, sendo influenciado também pelo psiquismo, estado emocional do indivíduo(4,12).

Os fenômenos químicos são comandados pelas secreções ao longo do trato digestivo. As enzimas secretadas produzem as reações de hidrólise das proteínas, hidratos de carbono e gorduras, reduzindo-os a moléculas facilmente absorviveis. $O$ automatismo do funcionamento digestivo é assegurado por mecanismos nervosos e hormonais $(4,12)$.

Os diversos segmentos do tubo digestivo têm funções diferentes .Da boca até o estômago, há passagem do alimento por ação mecânica, e praticamente inexiste assimilação. Do estômago ao intestino delgado, ocorre a digestão e a absorção por ação química e, no intestino grosso, o armazenamento e a excreção, com absorção do excesso de água e minerais $(4,5,12)$.

Os nutrientes sofrem a ação dos sucos especificos de cada segmento do tubo digestivo. Dos hidratos de carbono, o amido, na boca, já se transforma em maltose e no intestino delgado, em glicose. As proteinas, no estômago, são cindidas em polipeptídios, proteoses e peptonas e, no intestino delgado, em peptídios e aminoácidos. As gorduras, no intestino delgado, são desdobradas em glicerol, ácidos graxos, colesterol, ácido fosfórico e bases(4,12). 
Essas funções podem estar prejudicadas nas doenças com alteraçōes morfológicas da mucosa e, dependendo da área e localização da lesão, o processo digestivo estará modificado para determinados nutrientes. As alterações morfológicas, os estados psicológicos e algumas condições físiológicas, podem alterar as funções químico-funcionais e requerer determinados nutrientes parcial ou totalmente digeridos para facilitar sua assimilação(4 11, 47). Em qualquer dessas situações, a proteina, por sua importância como elemento construtor do organismo e componente indispensável nas diferentes dietas, merece exame especial, visando sua melhor forma de consumo e assimilação.

A hidrólise das proteínas é iniciada pela ação da pepsina, enzima do estômago, mas também melhorada pela condição ácida do meio $(\mathrm{pH}=2$ a 3). Ao nivel do duodeno, outras enzimas, tripsina e quimotripsina, liberam peptídios de cadeia média ou curta, enquanto as carboxipeptidases iniciam a liberação dos aminoácidos para sua absorção. $(5,30,45,47,59)$. Dessa hidrólise resultam 25 a $30 \%$ de aminoácidos e 60 a $70 \%$ de peptídios de 2 a 6 unidades aminoacídicas captadas e absorvidas pela mucosa intestinal. Dependendo da natureza da proteína ingerida, ela terá absorção de 10 a $20 \%$ no duodeno, $60 \%$ no jejuno e o restante no ileo. ${ }^{(4,59)}$. Através da permeabilidade pequenos peptídios, não hidrolisados, representam $50 \%$ dos produtos da digestão das proteínas na luz intestinal. Pela presença das peptidases, de borda estriada e citosólicas, é provável que o grande fornecimento de nitrogênio que alcança a circulação portal esteja sob a forma de aminoácidos livres e a pequena parte de peptídios absorvida é rapidamente hidrolisada ao nível hepático(4, 52, 59).

A velocidade de absorção dos aminoácidos também foi objeto de estudos por ser importante à compreensão total do mecanismo, da osmolaridade e porcentagem de difusão no organismo. Em doenças como pancreatite, sindrome do intestino curto e doença de Crohn, as dietas devem minimizar a estimulação de secreções, ser de fácil absorção e não atuar na região inflamada, fatores estes influenciados pela forma e composição dos seus elementos $(47,51,52,59)$.

O conhecimento desses mecanismos é fundamental, pois os alimentos fornecedores de nutrientes se encontram em forma complexa, agrupádos, e não só na forma de proteinas. Em algumas condições de doença, pode ser 
essencial esses nutrientes estarem isolados, ou mesmo com outros, sob forma diferenciada, total ou parcialmente hidrolisados (51).

O conhecimento de alimentos fonte de proteina com o objetivo de suprir as dificuldades apresentadas em indivíduos doentes (sindromes dissabsortivas) ou em determinados estados fisiológicos (idosos, esportistas) que apresentam alterações de absorção por diferentes causas, vem se ampliando. Essas dificuldades ocorrem por deficiência de enzimas e alterações nas paredes intestinais ou no processo digestivo, cuja origem pode estar em fatores hereditários, distúrbios e/ou redução hormonal, imaturidade do sistema digestivo ou processos resultantes de cirurgias $(4,17,30$ ).

Doença de Crohn, colite ulcerativa, sindrome do intestino curto, pancreatite, doença celíaca, traumas severos, alergia alimentar são enfermidades que exigem a manutenção de adequado estado nutricional com dietas especificas, bem equilibradas e de máxima eficiência em sua absorção(2, 5, 47, 52).

MATHEUS e ADIB|(35) e SILK e colaboradores (52) estudaram formas de absorção das proteinas e mostraram que sua ingestão na forma parcialmente hidrolisadas é mais benéfica e vantajosa do que o uso de aminoácidos livres em dietas enterais. Os hidrolisados, entretanto, modificam o sabor pela presença de determinados aminoácidos livres e a carga osmótica (osmolalidade e taxa de infusão) da dieta pela velocidade e concentração em que são absorvidos.

O individuo doente apresenta condições fisiológicas diferenciadas, porque as necessidades nutricionais de seu organismo estão alteradas. Para obtenção de sucesso no tratamento, há necessidade de se elaborarem dietas devidamente adequadas a cada situação.

ZIEGLER e colaboradores(64) realizaram estudo prospectivo em 12 pacientes com cuidados intensivos, após cirurgia abdominal. Testaram 2 dietas enterais de iguais teores de nitrogênio e suprimento energético, mas diferenciadas na forma da proteina: hidrolisado de caseína e de soro de leite $(60 \%$ de pequenos peptídios) e outra com proteina integral de composição aminoacídica similar. Concluiram que a dieta com hidrolisado protéico foi de maior eficiência para esse tipo de paciente no restabelecimento dos niveis plasmáticos dos aminoácidos e das proteínas. 
No que diz respeito às alergias, a mucosa intestinal torna-se permeável às moléculas grandes (proteinas), que provocam reações alérgicas de maior ou menor extensão conforme as características do individuo. Conhecimentos sobre alimentos que atendam à especificidade das doenças são imprescindiveis. ROSADO e colaboradores(46) justificam assim 0 desenvolvimento de fórmulas com hidrolisados protéicos de diferentes fontes, bem como das enzimas proteoliticas utilizadas para sua obtenção.

FROKJAER (17) apresenta a aplicação de hidrolisados protéicos na alimentação de idosos que, geralmente, não consomem o suficiente para atender às suas necessidades por decréscimo de apetite, refeições sem companhia, doenças ou mesmo falta de auxilio para comer. Outra aplicação é na dieta de esportistas, na forma de bebida para reposição ou manutenção em algumas situações, a qual poderia também ser utilizada para indivíduos fazendo controle de peso, através de formulação balanceada.

Pesquisas, avaliando sinais clínicos e laboratoriais de individuos normo e hipertensos voluntários, mostraram o efeito da utilização do hidrolisado de caseína com tripsina, sugerindo sua aplicação como elemento de prevenção da doença(49).

NETTO(38) , em seu estudo sobre hidrolisado protéico de soja, obtido mediante a ação enzimática da pancreatina, visando sua aplicação em nutrição clinica, alcançou resultados satisfatórios. Foram utilizados ratos no ensaio biológico e comparou-se o aproveitamento de dietas com caseina, isolado de soja e hidrolisado de soja. Com o hidrolisado de soja de baixo peso molecular, a recuperação dos animais em depleção protéica foi mais rápida do que com a caseína.

Diversos estudos com hidrolisados de soja, soro de leite e caseina foram realizados, verificando-se a eficácia do preparado, com resultados sempre melhores do que para a proteina integra, principalmente os relativos aos quadros alérgicos $(3,17,34,36,56$,$) .$

AGGETT e colaboradores(3) comentam que os preparados à base de hidrolisados protéicos de leite, soja e carne, independentemente de seu grau de cisão, são fórmulas com baixo poder alergênico ou antígênico. 
VANDENPLAS e colaboradores (62), ao compararem o valor nutricional de duas fórmulas infantis, uma com soro integral e a outra com hidrolisado de soro, em crianças saudáveis, concluíram que a última pode ser utilizada, exclusivamente, do nascimento aos 3 meses de idade, com adequado desenvolvimento do organismo.

O emprego de fórmulas com hidrolisados protéicos na alimentação de crianças com riscos de processos alérgicos (eczemas) foi avaliado por MALLET \& HENOCQ(34) que verificaram resultados favoráveis quando sua introdução é precoce.

O uso clínico de hidrolisados protéicos e de fórmulas com soja na dieta de crianças com problemas gastrintestinais é recomendável, por conterem pequenos peptídios de assimilação mais fácil (36).

STEPHAN e colaboradores(56) avaliaram a utilização de hidrolisado protéico de leite em crianças com alergia à proteína do leite, observando ser eficiente em relação à redução de alergenicidade e imunogenicidade

Experiência clínica realizada por DONZELLI e colaboradores(14), em crianças com diarréia protraida e eczema atópico, apresentou melhores resultados para fórmula comercial com hidrolisado de carne, o qual parece não possuir propriedades alergênicas em ambas as situações, do que quando usou a fórmula à base de proteina de soja.

Para a produção de hidrolisados protéicos são utilizadas enzimas, ácidos ou álcalis, dando as primeiras de melhor resultado para preparados com a finalidade de aplicação nutricional. Os hidrolisados decorrentes do processo da acidez podem sofrer destruição de aminoácidos e ou apresentar substâncias tóxicas $(14,16)$.

Embora as enzimas façam parte dos alimentos naturais, elas também podem ser adicionadas durante o processo de industrialização, prática crescente por sua aplicação tecnológica como aditivo para promover sabor, emulsificação, estabilidade, conservação, aumento ou redução da solubilidade, aeração e coagulação do produto final( $(29,48,63)$. A seleção das enzimas depende do perfil 
do $\mathrm{pH}$ e temperatura do meio em que atuará, sítio de ação e extensão desejada de hidrólise $(29,63)$.

A utilização dos hidrolisados em dietas especiais com caracteristicas especificas vem sendo analisada no decorrer dos anos e LAHL \& BRANN(29), revendo as fórmulas alergênicas, agruparam-nas em 3 gerações de hidrolisados:

- fórmulas hipoalergênicas com caseina hidrolisada, onde $70 \%$ da composição são aminoácidos livres e peptidios com 8 unidades aminoacídicas ;

- proteinas hidrolisadas do soro de leite, com 40 a $60 \%$ de aminoácidos e peptídios com 12 unidades aminoacidicas;

- proteinas hidrolisadas do soro de leite com $20 \%$ de aminoácidos livres e peptídios com 15 unidades aminoacidicas.

Esses autores(29) acrescentam, ainda, que as enzimas utilizadas para a hidrólise são classificadas conforme a especificidade de ataque às ligações peptídicas. As misturas de exo e endopeptidases, como a pancreatina, podem fornecer o equilibrio desejado de aminoácidos e peptídios específicos, outras peptidases como as de origem vegetal, não são comparativamente tão seletivas e as microbianas podem ser mais seletivas

Atualmente as principais proteínas submetidas às diferentes ações enzimáticas são caseína, soro de leite, e da soja, mas também já foram realizadas pesquisas com as proteínas do peixe, da gelatina, e do ovo (albumina), como hidrolisados em dietas experimentais(16,29). Em geral, as enzimas utilizadas são isoladas e purificadas, podendo ser de origem animal, vegetal ou microbiana. A seleção de enzimas ou da mistura delas está baseada na capacidade de hidrolisar o substrato e seu potencial de redução em aminoácidos.

Pesquisas recentes mostraram que a papaina e a bromelina, enzimas proteoliticas do mamão e do abacaxi, respectivamente, apresentam bons resultados em relação à digestão de produtos $\operatorname{cárneos}^{(6,54,55)}$.

A maioria das enzimas comercializadas para amaciamento de carnes é de origem vegetal (a papaina, a ficina e a bromelina). Outras, de origem animal, também podem ser usadas, como a tripsina e a quimotripsina. $O$ rompimento ocorre no tecido conectivo e nas proteinas contráteis. A papaína, bromelina, ficina, tripsina e Rhozyme P-11 hidrolisam as proteínas solúveis da carne, mas 
a bromelina e a ficina degradam o colágeno, enquanto a elastina é somente degradada pela papaina e ficina. A papaina é 2 vezes mais ativa sobre a elastina do que a ficina. A ficina também é apontada por atuar rapidamente sobre as proteinas musculares, colágeno e elastina, enquanto a papaina tem menor e a bromelina maior efeito sobre o colágeno(16, 40).

A temperatura ótima de atividade varia entre as enzimas: $45^{\circ} \mathrm{C}$ para ficina, $50^{\circ} \mathrm{C}$ para bromelina, enzimas pancreáticas e enzimas microbianas, e de 67 a $70^{\circ} \mathrm{C}$ para papaina. As enzimas vegetais quando adicionadas à carne exercem maior efeito de hidrólise durante a cocção, por ela ser desnaturada pelo aquecimento. Essas enzimas continuam em atividade em $80^{\circ} \mathrm{C}$ e sofrem inativação em temperaturas mais elevadas (16, 40).

As enzimas proteolíticas de origem vegetal, como a actinidina do kiwi, a bromelina do abacaxi e a papaina do mamão, têm fraco potencial de sensibilização no que diz respeito ao desenvolvimento de quadros alérgicos ${ }^{119}$, 27). Estas enzimas estão agrupadas como proteinases tiol, têm características fisico-quimicas semelhantes, mas com peso molecular e ponto isoelétrico diferentes(19).

LAMOUNIER (31) desenvolveu metodologia para a caracterização bioquimica e nutricional do hidrolisado de farinha de carne bovina sem osso, utilizando pancreatina. Realizou ensaio biológico em ratos, comparando a caseina e hidrolisados de caseina e de carne, obtendo para os últimos melhores resultados, tendo o de carne apresentado maior percentual de peptídios.

PARK \& DRAETTA(40) trabalharam com carne bovina liofilizada, empregando as enzimas protease bacteriana, ficina, bromelina, tripsina e papaina isoladas, e verificaram a ação da temperatura sobre o grau de hidrólise e sua eficácia no amaciamento de carnes. Concluíram que essas enzimas atuam numa faixa de 60 a $90^{\circ} \mathrm{C}$, sendo a ficina a mais resistente e existindo correlação entre o grau de hidrólise e a extensão de alterações histológicas do tecido muscular.

TAKEDA \& OKEDA(58) hidrolisaram carne bovina com papaina isolada e posteriormente liofilizaram o hidrolisado para utilização em dietas especiais. $O$ produto serviu de ingrediente na formulação das dietas para sonda, alimentação de prematuros e desnutridos internados. A condição de liofilizado garantiu conservação por tempo maior. 
TRIGO \& SAKAKI (60) utilizaram o hidrolisado liofilizado desenvolvido por TAKEDA \& OKEDA(58) em crianças prematuras com controle domiciliar. Os autores concluíram que o hidrolisado liofilizado demonstrou ser um recurso para melhoria do estado nutricional das crianças estudadas.

BARUFFALDI e colaboradores $(8,9)$ estudaram a digestão enzimática da carne bovina, com três tipos de enzimas vegetais isoladas para utilização em dietas especiais. Observaram que a ordem decrescente de eficiência foi ficina, bromelina e papaina, e o produto final, liofilizado, manteve sua solubilidade e higroscopicidade.

ASAKURA (6), em estudo sobre carne bovina hidrolisada com enzimas isoladas de origem vegetal (papaina, bromelina e ficina), analisou a influência da temperatura, concentração e tempo de hidrólise sobre a solubilização das proteínas. Verificou que a temperatura mais favorável foi a de $60^{\circ} \mathrm{C}$, resultando em maior rendimento de sólidos solúveis, quando cerca de $50 \%$ do rendimento do hidrolisado são obtidos a partir de 15 minutos, com concentração mais eficiente em $0,2 \%$ de enzima.

STABILE (53) estudou a ação da papaina, da tripsina e da protease microbiana, isoladas e em misturas, sobre as proteinas da carne bovina. Observou que a papaína e a tripsina em relação aos parâmetros de hidrólise eram equivalentes, e a mistura de enzimas mais eficaz na obtenção de aminoácidos. Analisou, também, as propriedades de viscosidade e valores de graus Brix para a possibilidade de ser o hidrolisado empregado em dietas especiais.

Varios autores, em seus trabalhos $(6,8,29,31,33,47)$, relatam a utilização da enzima isolada, purificada, mas é preciso ressaltar o custo elevado desse processo que restringe sua aplicação prática nas dietas especiais em pequena escala.

STABILE e colaboradores (55) analisaram as condições para o maior rendimento de hidrolisados de carne (bovina, frango e peixe) a baixo custo, com suco de abacaxi in natura, obtendo resultados favoráveis para aplicação em dietas. Os valores de sólidos solúveis foram superiores àqueles obtidos com a enzima isolada e purificada e a carne de frango foi a mais susceptivel à hidrólise pelo suco de abacaxi da variedade Hawai. Esse estudo mostrou que 
existem recursos para orientar, inclusive em nivel ambulatorial, a elaboração de dietas especiais.

A otimização do método, utilizando-se suco de abacaxi in natura e a carne bovina, foi estudado por STABILE (54). Os resultados apresentaram produto com maior porcentagem de sólidos solúveis (aumento de $50 \%$ em relação ao inicial), e o tipo de enzima e a temperatura não afetam a solubilidade das proteinas da carne. $O$ valor de $\mathrm{pH}$ interfere sobre a atividade enzimática e as condições microbiológicas mantiveram-se adequadas .

Sendo de fácil manipulação, aquisição e de menor custo do que as enzimas proteoliticas industrializadas (isoladas), pesquisas sobre a carne hidrolisada utilizando o abacaxi in natura, um fruto tropical que tem produção o ano inteiro, abriram novas perspectivas no campo da nutrição. Encontra-se a bromelina em todas as partes da planta e do fruto, mas, para sua comercialização, utiliza-se mais o caule do abacaxizeiro maduro, com maior concentração da enzima, pouco se aproveitando o teor da casca, fruto, folhas e coroa(25,50).

O processo da hidrólise promove a mudança de diversas propriedades físicoquímicas da proteina, como solubilidade, viscosidade, retenção de água, estabilidade durante $o$ armazenamento, qualidade organoléptica e eficácia nutricional ou biológica do produto final(13,33,48). Estas alterações podem ser ou não desejáveis no produto final e dependem da especificidade da enzima e condiçōes do processamento. Quando há presença de sais, ácidos e necessidade de aquecimento, ocorre também a desnaturação da proteina que, entre outros efeitos, reduz a solubilidade, altera a capacidade de fixação da água, diminui sua atividade biológica, aumenta a susceptibilidade ao ataque das proteases, cresce a viscosidade intrinseca, evita a cristalização, altera a gelificação ou coagulação segundo porcentagem de constituintes hidrófobos, aumentam a reatividade dos grupos funcionais (tiol da cisteina e fenol da tirosina)(13,44).

O pigmento principal presente nas carnes é a mioglobina que determina a cor do produto pela sua concentração e é considerado um dos índices de qualidade das carnes para o consumidor. Por isso, este fato deve ser levado em conta quando se avaliam preparados à base de carnes. A concentração da mioglobina varia com a espécie do animal, fato constatado por LIVINGSTON E BROWN (32) que reuniram dados de diversos autores: $2,0-5,0 \mathrm{mg} / \mathrm{g}$ de peso em 
carne bovina; $4-7 \mathrm{mg} / \mathrm{g}$ em carne de cordeiro; $2,5-7,0 \mathrm{mg} / \mathrm{g}$ em carne de porco; 1-2 $\mathrm{mg} / \mathrm{g} \mathrm{em}$ carne escura de aves e 0,5-1,0 mg/g na carne clara de atum. Essas concentrações variam com o tipo de músculo, certos fatores genéticos, e tipo de abate. A mioglobina, proteína que contém o núcleo heme com o ion ferro em seu centro, é influenciada pelas mudanças que ocorrem na valência deste mineral, promovendo as variações de cores (de vermelho a marrom). $\mathrm{E}$ por ser esta molécula uma proteína sofra influencia também da desnaturação promovida pelo calor e $\mathrm{pH}$, expondo-a a reações diversas, alterando suas propriedades citadas anteriormente $(13,33,42,44,48)$.

TORRES e colaboradores(61) analisaram carne bovina em estágios de pré e pós rigor e observaram a ação de sal e pH sobre a mioglobina. Os resultados sugerem que a adição de sal promove a oxidação da oximioglobina em $\mathrm{pH}$ baixo, e que a adição de sal no estágio pré rigor estabiliza a cor.

Comportamento semelhante da mioglobina, foi verificado em sistema modelo com extratos sarcoplasmáticos e adição de sal por ASGHAR e colaboradores(7) sugerindo que a estabilidade da cor também foi propiciada pela ação enzimática das organelas subcelulares bem como pela depressão do crescimento microbiano.

Dependendo da faixa do $\mathrm{pH}$ a acidez é uma propriedade que auxilia na preservação do estado microbiológico por impedir o crescimento de microorganismos e atuar sobre o pigmento da carne. No estado natural, as carnes e as frutas são ligeiramente ácidas, e os pHs encontram-se na faixa de 5,4 a 5,8 e 3,7 a 4,5 , respectivamente(23).

A osmolalidade é uma caracteristica importante em fórmulas nutricionais, com diversas fontes de proteina, para evitar diarréias e distúrbios sérios nos pacientes que recebem dietas hipertônicas ou hiperosmolares.

Em relaçào às formulações com hidrolisados foi abordado por MAHMOUD (33) a possibilidade da interação do amido com o hidrolisado protéico, que, durante - processamento, contribui para a estabilidade da emulsão, podendo influenciar as modificações das propriedades reológicas do produto, interações estas não previstas na literatura. 
O produto resultante da hidrólise apresenta certa desvantagem, pois a combinação de algumas proteinases e substratos produzem peptidios amargos. Esse amargor, em geral é devido à alta hidrofobicidade, especialmente se o resíduo $C$ terminal é hidrofóbico. Esse sabor pode ser eliminado ou reduzido pelo tratamento com carvão ativo, carboxipeptidase $A$, aminopeptidase-leucina, ultrafiltração, reação plasteína, e mascarado com adição de polifosfatos, gelatina ou amido gelatinizado(16,42,42). A maioria dos sitios hidrofóbicos encontra-se escondida no interior das moléculas globulares da proteina, não podendo, portanto, interagir na forma de complexo.

OLIVEIRA e colaboradores(39) elaboraram e analisaram dietas enterais à base de carnes hidrolisadas (bovina, frango e peixe) com suco de abacaxi in natura (fonte de bromelina), obtendo resultados semelhantes aos das dietas comercializadas.

Com pequenas exceções, as pesquisas nessa área foram realizadas com produtos elaborados em condições laboratoriais especiais. Os produtos formulados industrialmente, com técnicas avançadas de obtenção, deram grande impulso ao conhecimento e esclarecimento de reações e comportamentos nos diferentes estados patológicos em face dos mais diversos alimentos formulados. Entretanto, quando na comunidade são necessários esses produtos e o paciente não está mais internado e sim assistido ambulatorialmente, enfrenta-se o grande problema do custo de manutenção da dieta .

Está comprovada a eficiência do uso de hidrolisados em diferentes situações patológicas que requerem dietas especiais. A sua aplicação, seja em formulações comerciais ou para elaboração em pequena escala, necessita ser ampliada e adaptada o mais precocemente às situações e ao meio em que convive o individuo.

Estudam-se muito as fórmulas enterais, mas sua transição para a dieta oral, que deve ser gradativa, sem causar estresses fisiológicos e emocionais,.continua não sendo privilegiada pelas pesquisas.

A utilização de enzimas para amaciamento de carnes já resultou em produtos comercializados no mercado consumidor, mas não está totalmente explorada com o objetivo exclusivo de aplicação em dietas. Há necessidade, ainda, de 
estudos sobre ser a utilização em preparações aceitáveis para emprego em dietas especificas.

A dietoterapia evoluiu muito. Os hospitais contam com recursos para garantir a recuperação do indivíduo internado, mas não garantam o mesmo nivel de assistência à distância, com a mesma tecnologia ao seu alcance. Os nutricionistas têm obrigação de orientar as dietas conforme a realidade do paciente, considerando que seu periodo de permanência em hospitais é cada vez mais reduzido, de modo a integrá-lo o mais rapidamente ao convivio dos familiares, o que implicam o retorno à sua alimentação via oral.

Diversos serviços hospitalares de nutrição estão desenvolvendo preparações simples, de uso habitual e recursos domésticos para facilitar e garantir a continuidade do seguimento das dietas pelo paciente externo e a conseqüente recuperação de seu estado nutricional. A elaboração dessas dietas nem sempre se constitui em uma simples adaptação. São necessários conhecimentos de interações que podem ocorrer entre os alimentos e a forma de prevení-las e lou mascará-las para garantir sua aceitação. $O$ objetivo deste estudo não é somente oferecer variações nos cardápios, mas também apresentar novos recursos que podem ser utilizados em preparações fáceis, de maior valor nutricional e ao alcance da população, independentemente de sua classe sócio-econômica. 
II - OBJETIVOS 


\section{II - OBJETIVOS}

\section{GERAL}

Estudar a aplicação de hidrolisados de carne bovina, de peru e de frango com suco de abacaxi em algumas preparações culinárias para uso em dietas especiais.

\section{ESPECÍFICOS}

1 - Adaptar preparações utilizando o hidrolisado.

2 - Determinar a composição centesimal das carnes e seus hidrolisados.

3 - Calcular o valor nutritivo das diferentes preparações elaboradas.

4 - Verificar o padrão de aceitabilidade das preparações adaptadas. 


\section{III - MATERIAL E MÉTODOS}




\section{III - MATERIAL E MÉTODOS}

\section{1 - Material}

\section{1 - Carnes}

Para a realização deste estudo foram utilizadas carnes bovina (corte - coxão mole), de peru (corte - peito) e de frango (corte - peito), cortes comercializados. Foram recebidos 6 lotes dos três tipos de carnes para elaboração dos hidrolisados e sua aplicação nas preparações.

\section{2 - Enzimas proteolíticas}

Como fonte de bromelina, enzima proteolítica, foi utilizado o suco do abacaxi maduro (Ananas comosus L.) , fresco e das variedades Hawai e Pérola.

\section{3 - Receitas selecionadas}

Foram selecionadas a sopa, o bolinho, a vitamina e a musse (preparação à base de gelatina) por serem consideradas preparações comuns em nossa alimentação e de fácil manipulação..

Coletâneas especializadas e dicionários conceituam as preparações selecionadas com pequenas variações. Optou-se pela apresentada por FERREIRA(15).

SOPA: "caldo de carne, legumes, massas ou outra substância sólida".

BOLINHO: "pequena porção de massa de forma arredondada, preparada com qualquer ingrediente culinário, e geralmente frita". No salgado acrescentam-se sobras de legumes, verduras, carnes, peixes e aves.

VITAMINA: "creme ralo preparado com fruta(s) e ou legume(s), a que se adiciona água, leite ou suco, batendo-se tudo no liqüidificador". 
MUSSE: "iguaria doce ou salgada, de consistência cremosa e leve,feita com um ingrediente básico (chocolate, frutas, queijo,etc.) a que se adicionam claras batidas e/ou gelatina,e servida fria". Preparação de consistência leve e porosa, semelhante a uma espuma.

As receitas foram retiradas de livros de culinária, folhetos de indústrias distribuidos para a população (ANEXOS 4, 5, 6, 7 ).

Os alimentos utilizados foram adquiridos em mercados da cidade de São Paulo, sendo levadas em consideração as suas características de frescor e integridade.

\section{4-Equipamentos}

Foram utilizados talheres e xícaras padrão. Os utensílios domésticos para o preparo dos hidrolisados e execução das receitas foram: multiprocessador (moer a carne), centrifuga (extração do suco), fogão a gás, panelas de alumínio, liquificador e geladeira.

\section{2 - Métodos}

\section{1 - Hidrólise da carne}

\subsection{1 - Extração do suco de abacaxi}

A fruta foi cuidadosamente lavada, descascada, fracionada e seu suco extraido em centrífuga .

\subsection{2 - Preparo da carne}


Das carnes retiraram-se tendões, nervos, peles e as partes gordurosas aparentes, sendo, posteriormente, moidas.em multiprocessador.

\subsection{3 - Hidrólise}

A carne e o suco em iguais proporções $(1 \mathrm{~kg}$ de carne $/ 1 \mathrm{~kg}$ de suco) foram homogeneizados, colocados em pirex e levados em banho maria $\left(60^{\circ} \mathrm{C}\right)$ por 30 minutos. Posteriormente, colocados em calor direto até fervura, por 5 minutos e peneirados.

Os hidrolisados foram preparados no laboratório de Técnica Dietética da Faculdade de Saúde Pública, em condições semelhantes às domésticas, por equipe treinada ( 2 alunos do último ano do Curso de Nutrição e o pesquisador).

\section{2 . 2 - Composição centesimal dos hidrolisados}

Dos 6 lotes das carnes in natura, utilizadas no estudo, retiraram-se amostras de cada tipo (bovino, frango e peru) - $300 \mathrm{~g} / \mathrm{remessa}$, bem como dos seus hidrolisados correspondentes para análise $-300 \mathrm{ml} / \mathrm{hidrolisado} / \mathrm{lote}$.

Os resultados foram analisados estatisticamente para detectar diferenças significativas, aplicando-se o teste t pareado.

\subsection{1-Umidade}

Determinação por gravimetria, após secagem do material em estufa a $105^{\circ} \mathrm{C}$ até peso constante(24).

\subsection{2-Gordura}

Determinação pela extração contínua em aparelho do tipo Soxhlet(22). 
Extração da gordura com éter de petróleo e éter etílico (1:1) e solução de sulfato de sódio(10).

Metilação e saponificação com metanol e hidróxido de sódio, cloreto de amônio e ácido sulfúrico. Extração com éter de petróleo. As amostras metiladas foram analisadas em cromatógrafo a gás HP 5890, equipado com detector de ionização de chama e integrador HP 3396. A coluna utilizada foi capilar $(50 \mathrm{~m} x$ $0,32 \mathrm{~mm} \times 0,17 \mu \mathrm{m}), \mathrm{HP}-20 \mathrm{M}$ de carbovax. Utilizou-se um programa com: temperatura inicial $130^{\circ} \mathrm{C}$, temperatura final $200^{\circ} \mathrm{C}$ e $5^{\circ} \mathrm{C}$ por minuto(21). Para identificação dos ácidos graxos foram realizados testes contendo padrões de ésteres metilicos (marca Sigma RM3 e RM6).

\section{2,3-Proteina}

Determinação pelo método micro Kjedahl, empregando-se o fator 6,25 para o cálculo da proteina(24).

\subsection{4-Carboidratos totais}

O cálculo foi realizado por diferença.

\subsection{5-Acidez}

Utilizado o potenciômetro DMPH-2, marca DIGIMED .

\section{3 - Preparações}

As receitas foram selecionadas, observando-se a presença de líquido como ingrediente. As preparações foram executadas após identificação para serem consideradas como padrão e conhecer sua técnica de preparo.

Estudou-se a ordem de adição e determinou-se a quantidade do hidrolisado que poderia ser utilizado nas preparações, visando o resultado final desejado, 
mais semelhante ao padrão. A substituição pelo hidrolisado obedeceu a diluições estabelecidas conforme o tipo de preparação, levando-se em conta as caracteristicas sensoriais (cor, sabor, odor, textura), rendimento e facilidade de preparo.

Conforme a preparação, o número de sessões até a obtenção daquela considerada semelhante à padrão variou, pois houve necessidade de serem observados: quantidade dos ingredientes, proporção de líquidos, mistura de sabores com diversos condimentos, recursos para eliminar a influência da cor, seqüência de preparo e tipo de equipamento utilizado.

Ao final de cada teste, realizaram-se discussões com a equipe para a conclusão da preparação: semelhança com a padrão e modificações necessárias. As aprovadas foram apresentadas para análise sensorial

\section{4 - Valor nutritivo das preparações}

Calculado a partir do programa de computador (NUTRI-HNT), elaborado no Departamento de Nutrição da Faculdade de Saúde Pública, cujos dados são compilaçōes de várias tabelas nacionais e estrangeiras, tendo como base a Tabela de Composição de Alimentos do ENDEF - FIBGE(18).

Foram comparados os teores dos nutrientes disponiveis no programa entre as preparações com e sem os três hidrolisados.

\section{5 - Análise sensorial}

Para o teste de aceitação das preparações, recorreu-se ao método afetivo da escala hedônica estruturada verbal. Neste teste, o provador expressa o grau com que gosta ou desgosta das amostras, utilizando uma escala onde expressões verbais hedônicas são valores numéricos para a análise estatística dos resultados $(37)$. 


\section{Escala hedônica:}

9 - gostei extremamente

8 - gostei muito

7 - gostei moderadamente

6 - gostei ligeiramente

5 - nem gostei nem desgostei

4 - desgostei ligeiramente

3 - desgostei moderadamente

2 - desgostei muito

1 - desgostei extremamente

Na ficha de avaliação foram solicitadas também a faixa etária e observações a respeito da preparação no sentido dos aspectos que mais ou menos gostou (ANEXO 1).

Foram apresentadas aos degustadores 4 preparações para avaliação (sopa de beterraba, bolinho de batata, vitamina de legumes e fruta e musse de uva), necessitando assim de 3 sessões de degustação, uma para cada hidrolisado (bovino, frango e peru).

A avaliação sensorial contou com degustadores não treinados, individuos de ambos os sexos, funcionários, professores e alunos da Faculdade de Saúde Pública, sendo que todos tiveram conhecimento dos diferentes tipos de preparação e não manifestaram rejeição ao produtos a serem degustados. Participaram das duas primeiras sessões 40 pessoas e da terceira 50 , número adequado para o tipo de teste conforme STONE e SIDEL(57). Pelo menos, 30 dos degustadores foram os mesmos para as 3 degustações.

Os testes desenvolveram-se em cabines individuais no Laboratório de Técnica Dietética do Departamento de Nutrição da Faculdade de Saúde Pública. 
Para a análise do experimento, utilizou-se o delineamento estatístico através da análise de variância (ANOVA) e teste de Tukey. O nivel de confiança adotado foi $95 \%$. A escala de valores na ficha de avaliação variou de 1 para "desgostei extremamente" até 9 para "gostei extremamente".

A preparação foi considerada como aceita quando a maior porcentagem dos degustadores apresentou resultado, pelo menos, como gostei ligeiramente na escala apresentada. 
IV - RESULTADOS E DISCUSSÃO 


\section{1 - COMPOSIÇÃO CENTESIMAL DAS CARNES IN NATURA E SEUS HIDROLISADOS}

A TABELA 1 apresenta a média da composição centesimal da carne bovina în natura e seu respectivo hidrolisado, resultante da análise de 6 amostras correspondentes a cada lote (ANEXO 2). Observa-se que, entre a carne in natura e o respectivo hidrolisado, houve aumento da umidade e diferença de $50 \%$ no teor protéico, considerado esperado tendo em vista que o hidrolisado contém o suco de abacaxi. Em relação aos carboidratos, sua presença também é devida à presença do abacaxi no hidrolisado, mas não houve diferença do teor de gordura total e dos ácidos graxos encontrado entre os dois.

TABELA 1 - Composição centesimal média (desvio padrão) da carne bovina in natura ( 1 ) e seu hidrolisado $(H)$. *

\begin{tabular}{|c|c|c|}
\hline CONSTITUINTE & 1 & $\mathrm{H}$ \\
\hline Umidade & $74,26(0,84)$ & $80,66(0,61)$ \\
\hline Cinza & $1,33(0,23)$ & $0,81(0,04)$ \\
\hline Carboidratos & - & $5,10(0,85)$ \\
\hline Proteina & $22,47(1,59)$ & $11,99(1,18)$ \\
\hline Gordura Total & $1,59(0,61)$ & $1,44(0,33)$ \\
\hline Saturados ** & $0,73(0,03)$ & $0,67(0,04)$ \\
\hline Monoinsaturados ** & $0,68(0,03)$ & $0,62(0,04)$ \\
\hline Polinsaturados ** & $0,11(0,01)$ & $0,09(0,01)$ \\
\hline
\end{tabular}

* Média de 6 amostras.

Para a carne "in natura" a unidade é g/100 g e para o hidrolisado $\mathrm{g} / 100 \mathrm{ml}$.

* Média de 5 amostras. 
A redução constatada no hidrolisado, relativa ao teor protéico, corresponde à diluição utilizada no preparo do hidrolisado, partes iguais de suco de abacaxi e de carne, justificando, portanto, o maior percentual de umidade. Estatisticamente as médias da umidade, cinza e proteina da carne in natura e seu hidrolisado são significativamente diferentes. $O$ teor protéico reduzido do hidrolisado pode parecer desvantagem, mas é um produto com melhores condições de absorção, uma vez que a proteína está cindida, conforme apresentado por STABILE(54) sendo esta característica favorável a inúmeras aplicações dietoterápicas, como sua utilização em quadros alérgicos, má absorção $(3,14,34,47)$.

No que diz respeito à gordura total não apresentou diferença entre a carne bovina e o hidrolisado. Como no preparo do hidrolisado existe a fase de retirada de gordura externa e aquecimento, e na carne bovina existe a gordura interna, ocorreu sua dissolução, mantendo teor próximo ao da carne in natura. Este resultado sugere que, apesar dos cuidados no preparo de amostras semelhantes para análise e elaboração do hidrolisado, pode ocorrer diferença entre duas partes de um mesmo corte da carne, sendo um de maior teor de gordura interna do que o outro.

Comparando-se o teor de gordura total observado nas amostras de carne bovina com os encontrados em tabela nacional de composição centesimal (18) $6,1 \mathrm{~g} / 100 \mathrm{~g}$; nota-se que é muito inferior, provavelmente pelo fato da retirada da gordura externa total antes de sua dosagem (TABELA 1).

A composição de ácidos graxos da carne bovina in natura e de seu hidrolisado está apresentada no ANEXO 3, sendo que o oleico (C 18:1) é aquele que se encontra em maior proporção, seguido pelo palmítico (C 16:0) e pelo esteárico (C18:0). Resultados semelhantes foram verificados por JULLA (26). Observouse também que os teores a gordura total entre a carne e seu hidrolisado não foram muito diferentes (TABELA 1 ) e menos de $10 \%$ dos ácidos graxos são polinsaturados. Essa manutenção de valores semelhantes mostra que a técnica de preparo pouco interferiu no hidrolisado e manteve a presença de ácidos graxos essenciais. A porcentagem de ácidos graxos saturados encontrada foi menor $45,79 \%$, do que as verificadas por PITRE - 52,7 e GIRARD e colaboradores - 48,0 citada em revisão de JULLA(26). 
A TABELA 2 apresenta a composição centesimal média da carne de peru in natura e seu hidrolisado, aonde observamos que houve reduções significantes em seus constituintes, aproximadamente $50 \%$ no teor de proteina, cinzas e gordura total e aumento na umidade do hidrolisado. Estas modificações são devidas à presença de maior diluição pelo suco de abacaxi (1de suco /1 de carne) no processo de hidrólise da carne.

O teor de carboidratos é devido à presença do abacaxi no preparado, uma vez que este não está presente nas carnes in natura.

TABELA 2 - Composição centesimal média (desvio padrão) da carne de peru in natura $(\mathrm{I})$ e seu hidrolisado $(\mathrm{H})$. $^{*}$

\begin{tabular}{l|c|c}
\hline CONSTITUINTE & I & H \\
\hline Umidade & $73,42(1,36)$ & $80,93(0,78)$ \\
Cinza & $1,46(0,28)$ & $0,78(0,05)$ \\
Carboidratos & - & $4,97(1,23)$ \\
Proteina & $24,49(1,44)$ & $12,42(1,10)$ \\
Gordura Total & $1,48(0,69)$ & $0,73(0,36)$ \\
$\quad$ Saturados ** & $0,55(0,06)$ & $0,28(0,02)$ \\
Monoinsaturados ** & $0,50(0,06)$ & $0,20(0,03)$ \\
Polinsaturados ** & $0,40(0,10)$ & $0,21(0,03)$ \\
\hline
\end{tabular}

* Média de 6 amostras.

Para a carne "in natura" a unidade é g/100 $\mathrm{g}$ e para o hidrolisado $\mathrm{g} / 100 \mathrm{ml}$.

** Média de 5 amostras.

Outro aspecto a ser considerado na redução, em especial, da gordura é o da própria técnica de obtenção do hidrolisado, pelo fato da retirada das aparas (tendões, gorduras, fibras) ser feita manualmente, sempre pelos mesmos indivíduos, e peloo processo de peneiramento a gordura pode ficar retida junto ao residuo remanescente (provavelmente elastina, colágeno e aponevroses das carnes), o que na prática foi uma quantidade muito pequena. Nota-se que a gordura da carne de peru é mais externa do que a da bovina, retendo apenas elementos pouco solúveis ou não no produto final.

Dado obtido em tabela nacional de composição centesimal (18) para a gordura de carne de peru foi de $6,6 \mathrm{~g} / 100 \mathrm{~g}$, verificando que é maior do que o valor encontrado nas amostras analisadas (TABELA 2). Essas diferenças nos 
valores pode ser justificada pelo fato das amostras sofrerem retirada da gordutra aperente, enquanto que as tabelas não fazem referência a sua técnica de preparo da amostra.

A composição dos ácidos graxos não apresentou diferenças entre a carne in natura e o seu hidrolisado. A maior concentração é do oleico (C 18:1), seguido pelo linoleico(C18:2) e pelo palmítico (C16:0) (ANEXO 3), e apenas $30 \%$ aproximadamente, deles são polinsaturados, confirmando a presença de ácidos graxos essenciais no hidrolisado.

Os resultados obtidos para a carne de frango estão na TABELA 3. Observouse também redução de aproximadamente $50 \%$ de cinzas, proteina e gordura total nos teores do hidrolisado e maior umidade, consequência da diluição com suco de abacaxi, sendo ele também responsável pela presença dos carboidratos

TABELA 3 - Composição centesimal média (desvio padrão) da carne de frango in natura ( 1 ) e seu hidrolisado $(H) .{ }^{*}$

\begin{tabular}{l|c|c}
\hline CONSTITUINTE & I & H \\
\hline Umidade & $74,40(1,36)$ & $81,15(0,64)$ \\
Cinza & $1,71(0,56)$ & $0,83(0,07)$ \\
Carboidratos & - & $4,58(1,04)$ \\
Proteina & $23,88(0,76)$ & $12,62(0,37)$ \\
Gordura Total & $1,03(0,34)$ & $0,83(0,15)$ \\
Saturados ** & $0,34(0,02)$ & $0,29(0,01)$ \\
Monoinsaturados ** & $0,45(0,04)$ & $0,36(0,02)$ \\
Polinsaturados** & $0,21(0,03)$ & $0,16(0,03)$ \\
\hline
\end{tabular}

* Média de 6 amostras .

Para a carne "in natura" a unidade é g/100 g e para o hidrolisado $\mathrm{g} / 100 \mathrm{ml}$.

** Média de 5 amostras.

A redução da gordura foi consequente da diluição e difere em relação a valores encontrados em tabela nacional de composição centesimal (18) -frango $3,3 \mathrm{~g} / 100 \mathrm{~g}-$, pela técnica de retirada das gorduras externas (peles, tendōes e aponevroses) antes das análises e preparo do hidrolisado não constando em tabelas se ocorre esta retirada para suas análises. Em relação aos ácidos graxos, não foi observado muita diferença na sua distribuição (TABELA 3), e o de maior concentração foi o oléico (C 18:1), seguido pelo palmítico (C16:0) e pelo linoleico (C18:2) (ANEXO 3 ) e uma pequena porcentagem dos ácidos 
graxos são poliisaturados, confirmando a existencia dos ácidos graxos essenciais em sua composição. JULLA(26) em levantamento sobre porcentagem de ácidos graxos saturados em relação aos ácidos graxos totais, apresenta valor de 28,0 , dado de GIRARD e colaboradores, sendo este, no entanto, inferior ao obtido nas análises realizadas no estudo,que foi de $32,87 \%$.

Vale a pena ressaltar que a carne bovina mostrou valor mais elevado de saturados que o das carnes de peru e de frango, dados concordantes com os apresentados por JULLA (26).

Pela influência do $\mathrm{pH}$ na mudança dos pigmentos, e características funcionais das proteínas e ação na preservação microbiológica(7,32) são apresentados os valores obtidos nas análises das carnes in natura e dos hidrolisados, na TABELA 4.

TABELA $4: \mathrm{pH}$ das carnes bovina, peru e frango in natura (I) e seus respectivos hidrolisados $(H)^{*}$

\begin{tabular}{l|c|c|c|c|c|c}
\hline \multirow{2}{*}{$\begin{array}{l}\text { CARNES } \\
\text { amostra }\end{array}$} & \multicolumn{2}{|c|}{ BOVINA } & \multicolumn{2}{c|}{ PERU } & \multicolumn{2}{c}{ FRANGO } \\
\cline { 2 - 7 } & $\mathrm{I}$ & $\mathrm{H}$ & $\mathrm{I}$ & $\mathrm{H}$ & $\mathrm{I}$ & $\mathrm{H}$ \\
\hline 1 & 5,63 & 4,93 & 5,69 & 4,95 & 5,77 & 4,83 \\
\hline 2 & 5,45 & 5,00 & 5,72 & 5,21 & 5,74 & 5,23 \\
\hline 3 & 5,69 & 4,22 & 5,88 & 4,30 & 5,76 & 4,95 \\
\hline 4 & 5,50 & 4,43 & 5,77 & 4,68 & 5,51 & 4,58 \\
\hline 5 & 5,69 & 4,59 & 5,49 & 4,56 & 5,69 & 4,49 \\
\hline 6 & 5,62 & 4,97 & 5,87 & 4,96 & 5,71 & 5,02 \\
\hline MÉDIA & 5,56 & 4,69 & 5,80 & 4,78 & 5,70 & 4,85 \\
\hline $\begin{array}{l}\text { Desvio } \\
\text { padrão }\end{array}$ & 0,10 & 0,33 & 0,08 & 0,03 & 0,10 & 0,28 \\
\hline
\end{tabular}

* média de 6 amostras

Observou-se que o $\mathrm{pH}$ das carnes in natura é semelhante, o mesmo ocorrendo com seus hidrolisados. Os resultados estão na faixa de acidez para as carnes in natura, aproximadamente 5,7 , e para os hidrolisados 4,9 , sendo estas consideradas estatisticamente diferentes. Essa acidez para os hidrolisados é importante, por ser produto que poderá ficar armazenado sob refrigeração como apresentado por STABILE e colaboradores (55), portanto, com menor chance de contaminação. Nessa faixa de pH ocorre também a descoloração da mioglobina, tornando presente a metamioglobina, responsável pela coloração 
mais forte no hidrolisado de carne bovina (marron) por ser mais rica em pigmentos, entre as tres carnes utilizadas(32,37).

\section{2 - PREPARAÇÕES}

A sopa foi desenvolvida como indicado na receita padrão (ANEXO 4) sopas de legumes (creme ou em pedaços). No seu preparo houve necessidade de adaptações na técnica, pois o hidrolisado, dependendo do momento em que era adicionado, promovia sabores não desejáveis, de intensidade diferente. $O$ sabor mais intenso ocorreu com a utilização do hidrolisado de carne bovina, apresentando sabor férrico, semelhante ao de fígado bovino,não esperado para este tipo de preparação pela maior concentração do pigmento que contém ferro(32,37). Constatou-se este sabor quando adicionado no inicio do preparo, e acentuando-se com o tempo de fervura. Para os outros hidrolisados não se verificou essa interferência no sabor.

Em relação à cor, verificou-se pequena diferença entre os três tipos de hidrolisados, sofrendo o de bovino leve escurecimento, como já referido, consequência do teor de pigmentos ser maior do que o das carnes de peru e de frango. Realizaram-se 8 sessões práticas de laboratório até o ajuste final.

$\mathrm{Na}$ sopa de legumes selecionada, primeiramente em pedaços, utilizou-se cenoura, batata, chuchu, abóbora, mandioquinha, combinados diferentemente. Apenas a cor não estava totalmente adequada, pois os legumes ficavam ligeiramente marrons, principalmente quando da utilização do hidrolisado bovino, interferindo assim na identificação da sopa. A variação dos legumes $e$ suas combinações não foram suficientes para sanar esse aspecto, optou-se então por homogeneizá-las para obter cremosidade, mas notou-se que, dependendo do legume predominante, havia alteração da intensidade do sabor salgado com um suave amargor residual, melhorado com acréscimo do legume predominante. Com cremosidade e sabor adaptados, foi então preciso mascarar a cor, alterada com o uso do hidrolisado bovino, que escureceu e descaracterizou a sopa preparada, por exemplo, com a mandioquinha, dandoThe coloração marrom. O ajuste neste caso foi dado pela utilização da beterraba que, pela coloração intensa e sabor adocicado, supriu a questão da identificação da sopa, além de contribuir com seu sabor característico. Os 
hidrolisados de frango e peru não provocaram intensa alteração na cor das sopas anteriormente testadas, mas como o objetivo era a obtenção da mesma receita para os três hidrolisados padronizou-se a sopa. Neste sentido, para a análise sensorial, foi servida a sopa de beterraba, preparada com os três tipos de hidrolisado. A receita final do experimento consta no ANEXO 4.

O bolinho foi preparado com batatas (ANEXO 5). Como o liquido usado na preparação era o de cozimento das batatas, substituiu-se este pelo hidrolisado, verificando-se a sobra do líquido para o cálculo do seu valor nutritivo. Não se observou alterações na consistência da batata após o cozimento e mesmo na sua maniplulação, fato este que poderia ter ocorrido, conforme apresentado por MAHMOUD (33), interação do amido com o hidrolisado. Nenhum dos três tipos de hidrolisados interferiu na cor ou sabor da preparação, ou mesmo na consistência. Foram necessárias 5 sessões práticas de laboratório até $o$ acerto final da receita. A receita final adaptada está apresentada no ANEXO 5.

A escolha da receita da vitamina (ANEXO 6) levou em consideração a presença de um suco em sua formulação, para que este pudesse ser substituído total ou parcialmente pelo hidrolisado. Preparada com legumes e frutas (cenoura, tomate, maçã), leite condensado e hidrolisado em substituição ao suco de laranja, foram necessárias 8 sessões práticas de laboratório até a obtenção do produto desejado. A substituição total do suco pelo hidrolisado resultou num produto com alteração da cor, quando se utilizou o hidrolisado de carne bovina; os outros dois hidrolisados não apresentaram nenhuma modificação na cor. Este aspecto levou à análise das cores dos alimentos utilizados, bem como da técnica de preparo (utensílios e tempo de preparação), pois se observou que a intensidade das cores alterava com diferentes tempos de uso do liquidificador. Com a modificação dos tempos de liquidificação e a ordem de acréscimo dos ingredientes atenuou-se a quantidade de resíduos da vitamina. Apesar do abacaxi in natura não ser adicionado à vitamina, percebeu-se o sabor da fruta proveniente do hidrolisado. A utilização do leite condensado também foi avaliada. Optou-se pela sua retirada ou mesmo redução, o que levou a sabor mais acentuado da fruta e legumes e a consistência mais fluida da vitamina. Foram utilizadas 8 sessōes para resultados satisfatórios.(ANEXO 6). 
Selecionou-se uma musse, em cuja receita (ANEXO 7) constasse como ingrediente um suco de fruta, gelatina sem sabor e açúcar. O hidrolisado substituiu parte do suco e foi o diluente da gelatina. Os primeiros testes, realizados com suco de abacaxi, tendo em vista sua presença no hidrolisado, indicaram inadequação na cor da musse: escura com o hidrolisado bovino e indefinida com os outros dois. A consistência final também não estava uniforme, separando-se em duas camadas: aerada, superior, e lisa, inferior. A melhoria da cor foi obtida com gelatina de uva e o leite condensado, que propicia uniformidade e consistência, mas a musse ficou muito doce. Experimentou-se a retirada do leite condensado, aumentando a quantidade de gelatina para compensar a consistência. Como o produto final ainda apresentasse 2 camadas (uma grande espumosa e outra menor arenosa), testou-se a receita com gelatina sem sabor, aumentando sua proporção, adicionada de açúcar e suco de uva congelado previamente, pois o batimento do gelo colaboraria com a aeração e com o endurecimento da preparação. Observou-se também que a gelatina deve ser inicialmente bem hidratada e dissolvida para evitar a ocorrência da sensação arenosa no produto final. Para a musse final, com caracteristicas satisfatórias, necessitou-se de 9 sessões de laboratório. A receita final está no ANEXO 7.

Pode-se observar, como já citado na literatura (41,42), que a presença do sabor amargo é resultante do processo de hidrólise sobre as proteinas que libera aminoácidos, responsáveis por tal sabor. Tendo em vista que são preparações com mais de um ingrediente, optou-se por mascarar o sabor pela utilização de condimentos, alimentos com sabor característico e gelatina, sendo esse um dos recursos recomendados para a retirada do amargor (16,41,42).

\section{3 - VALOR NUTRITIVO DAS PREPARAÇÕES}

Ao se analisar o valor nutritivo das preparaçōes com hidrolisado observa-se, em relação às receitas tradicionais, que:

- Nas sopas, a utilização da carne é habitual. Naquelas com hidrolisado tem-se a presença do abacaxi que não modifica o teor de proteina, praticamente o mesmo nas receitas original e adaptada (ANEXO 4). A contribuição do abacaxi é relativa à vitamina $\mathrm{C}$, triplicando o seu teor, e ao total de carboidratos, elevando-o de $20 \%$, cálculo baseado na Tabela de 
Composição de Alimentos (18), cujos valores são referentes à fruta crua. A presença dessa vitamina é vantajosa, significando melhor aproveitamento do ferro pelo organismo (18). Contudo, é necessário considerar que a fruta, no preparo do hidrolisado, sofre cocção, levando possivelmente à perda de parte do conteúdo da vitamina $\mathrm{C}$, sensivel ao calor. Entretanto, estudos de PINTO e SILVA ${ }^{(43)}$ e KING(28), com alimentos cozidos por diferentes métodos de cocção, mostraram que essa perda não foi total, fato que se pode levar em consideração para a sopa. Entre as sopas, nota-se que o teor de gordura é menor naquela preparada com hidrolisado de carne de frango, enquanto que aquela com hidrolisado de bovino apresenta menor valor em colesterol.(ANEXO 4). Ressalta-se que o teor de ácidos graxos essenciais nas preparações com carne bovina é ligeiramente menor do que naquelas com as outras duas carnes (TABELA 16). Entretanto, na análise do valor nutricional da sopa (ANEXO 4), o valor apresentado não inclui o conteudo de ácidos graxos essenciais da carne bovina, pelo fato de não constar esse dado na tabela de composição centesimal inserida no programa. O consumo de sopas é comum em nossa alimentação desde a infância até a idade avançada e, às vêzes, é o prato principal na refeição do individuo, portanto, dependendo da exigência orgânica do momento pode ser recurso de alto valor para as dietas. $\dot{E}$ muito utilizado também em dietas nos hospitais não só pela restrição dietoterápica que pode exigir, mas também pela condição de acamado, impossibilitando o indivíduo de se levantar.

- No bolinho de batata, a carne como ingrediente não é habitual, portanto, seu valor nutritivo foi melhorado com a presença do hidrolisado (ANEXO 5). $O$ teor protéico total é duplicado (de 26,8 para, pelo menos, $53,1 \mathrm{~g}$ ), e a proteina animal triplicada (de 14,0 para aproximadamente $40,0 \mathrm{~g}$ ), sendo aumentado também o teor de lipidios. $O$ teor de ácidos graxos essenciais na preparação com hidrolisado bovino não apresentou diferença em relação à sem carne, isto devendo-se ao fato da tabela do programa utilizado como base para os cálculos não apresentar o teor desse nutriente na carne bovina. Outros valores com diferenças significativas pela presença do hidrolisado na preparação foram o ferro $30 \%$, vitamina C $100 \%$ e potássio $40 \%$ a mais em relação à receita padrão. $O$ fato da proteina estar cindida e a presença vitamina $C$ pode levar melhor absorção(20), além de ter maior valor proteico, e maior teor de vitaminas (B1, B2, C a niacina) e de minerais (Ca, Fe, P, Mg, Ke $\mathrm{Na}$ ). A preparação, em questão sendo de consistência macia e paladar agradável pode ser acrescentada à alimentaçãode baixo consumo proteico por 
diferentas causas, como por exemplo, os idosos que apresentam problemas de dentição e crianças que não conseguem mastigar as carnes.

- A vitamina é uma preparação resultante da combinação de frutas e legumes alimentos estes utilizados como fontes de vitaminas, minerais e fibras. O consumo dessa preparação não visa suprir o aporte proteico e sim principalmente as vitaminas e o micronutrientes, mas é um recurso que dependendo da alimentação pode até ser aplicado. Quando se comparam as duas preparações, padrão e a adaptada (ANEXO 6) há melhoria no teor dos nutrientes, como 0 de proteína 5,6 vezes superior para os três hidrolisados, lipidios de 1,7 a 2,7 vezes, vitaminas $B 1, B 2$ e $C$ duplicadas, niacina de 7 a 15 vezes aumentada, o de ferro aproximadamente elevado de 3 a 6 vezes e em relação aos minerais fósforo, potássio e sódio duplicados. No que diz respeito aos ácidos graxos essenciais ocorreu a mesma dificuldade pelo uso do programa Nutri em relação a carne bovina $\mathrm{Em}$ dietas especiais pode ser utilizado com vantagens por seu valor nutritivo mais elevado e com melhor aproveitamento pelo organismo, tendo em vista a presença de ferro juntamente com a vitamina $\mathrm{C}$. Destaca-se porém que o teor de vitamina $\mathrm{C}$ do hidrolisado, como já referido, está reduzido pelo fato de sofrer cocção em sua preparação, diminuição desse teor em trono de 20 a $40 \%$ aproximadamente, dados de ACHINEWHU E HART(1) E SGARBIERI (50), que observaram as perdas no processamento de abacaxis.

- Na receita da musse selecionada contém gelatina que é produto muito utilizado tanto isoladamente como ingrediente em diversas preparações. Observa-se que o valor protéico da receita adaptada é duplicado, e sendo a proteína do hidrolisado de alto valor biológico, contribui para a melhoria da qualidade da presente na gelatina, que é de reduzido valor (ANEXO 7). Os outros nutrientes que apresentaram diferença foram: colesterol, vitaminas B1 e B2 elevadas em quase 100\%; niacina, aproximadamente, de 4 a 9 vezes superior; vitamina $C$, potássio e magnésio $50 \%$ mais altos e o fósforo triplicado, mostrando, assim, produto de valor nutricional superior ao original, sem o hidrolisado. O teor de ácidos graxos essenciais para a preparação com hidrolisado bovino inexiste pela tabela utilizada como base de cálculo, mas pelas análises realizadas nesse trabalho esse teor é diferente de zero. 
Frente a essas consideraçōes a preparação modificada apresenta grandes vantagens nutricionais visando dietas especiais, e mesmo pela preparação costumeira de gelatina se apresenta como uma variação possivel e fácil.

Pelos resultados apresentados pode-se concluir que as preparações adaptadas são de maior valor nutritivo, em algumas vitaminas e minerais e de proteinas que podem ter sua absorção facilitada pelo estado de hidrólise, mostrando a possibilidade de utilização, com vantagens, em dietas especiais.

\section{4 - ANÁLISE SENSORIAL}

As preparações foram as mesmas com os três hidrolisados de carne (bovino, peru e frango) e cada sessão realizada com apenas um tipo de carne. A seqüência do tipo da carne para a degustação foi aleatória: peru, bovino e frango .

Para análise sensorial consideraram-se todos os dados contidos na ficha de avaliação, idade, pontuação da escala hedônica e observações indicando o que o provador havia gostado. A graduação da escala 1, para desgostei extremamente até 9 para gostei extremamente, foi utilizada na análise estatistica.

Examinando-se os dados de cada preparação com os três hidrolisados, referentes à pontuação da escala hedônica, foram obtidos os resultados apresentados na TABELA 5 .

TABELA 5: Médias e desvios padrão obtidas em cada preparação com os três tipos de hidrolisado

\begin{tabular}{llc}
\hline preparação & média & desvio padrão \\
\hline sopa & 5.896 & 2.177 \\
bolinho & 7.520 & 1.490 \\
vitamina & 5.640 & 2.119 \\
musse & 6.994 & 1.961 \\
\hline
\end{tabular}


A preparação com maior média foi a do bolinho, correspondendo a gostei moderadamente.

A frequência e a aceitação das diferentes preparações são analisadas por tipo de hidrolisado.

\section{1 - Preparações com hidrolisado de carne bovina :}

A TABELA 6 mostra as médias e desvios padrão obtidos na análise estatística e as FIGURAS 1, 2, 3 e 4 apresentam a distribuição dos provadores (\%) em função dos valores marcados na escala. As manifestações dos provadores, a respeito das caracteristicas do que gostou, são apresentadas em proporção do número das observações anotadas

TABELA 6 - Médias e desvios padrão obtidas em cada preparação com o hidrolisado de carne bovina

\begin{tabular}{lcc}
\hline \multicolumn{1}{c}{ preparação } & média & desvio padrão \\
\hline sopa & & 1.916 \\
bolinho & 6.256 & 2.095 \\
vitamina & 6.923 & 2.095 \\
musse & 5.333 & 1.618 \\
\hline
\end{tabular}

Na FIGURA 1 observa-se que 16\% dos provadores optaram por gostei ligeiramente, $31 \%$ por gostei moderadamente, $26 \%$ gostei muito e $3 \%$ gostei extremamente, mostrando assim aceitação por cerca de $76 \%$ da população ou seja a preparação foi aprovada pela maioria dos degustadores ,segundo criterio adotado. Pela análise estatística não obtemos a porcentagem de aceitação porque média substima a maior concentração de valores marcados, gostei ligeiramente. 
FIGURA 1: Distribuição dos provadores (\%) em função dos valores hedônicos marcados na escala para a sopa com hidrolisado de carne bovina.

\section{PORCENTAGEM}

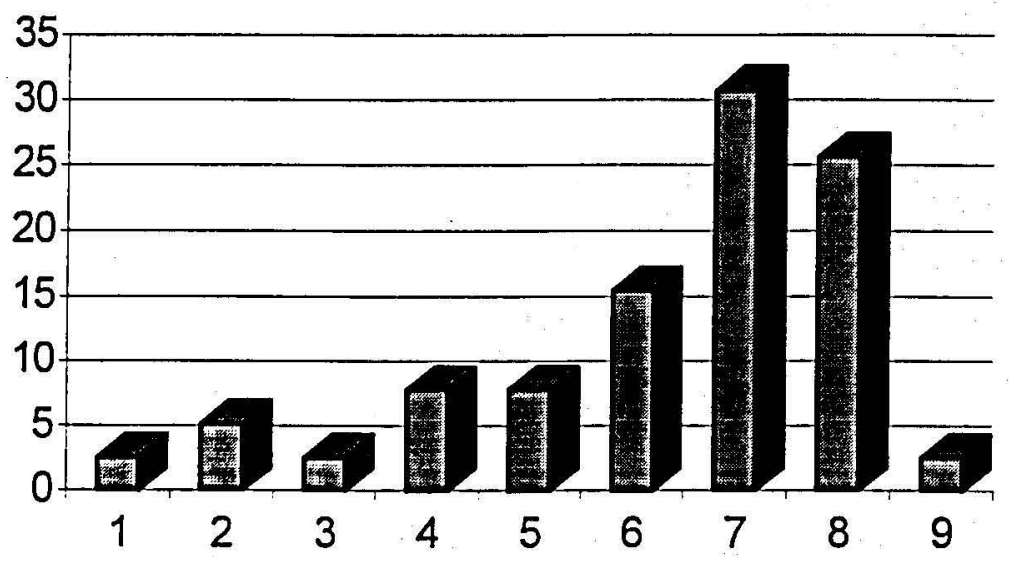

\section{ESCALA HEDÔNICA}

As observações citadas em relação à sopa foram a respeito da cor, consistência, sabor e tempero agradáveis (20\%), entretanto, referências a um leve sabor residual amargo (7.5\%), cor não definida (2\%), sabor de fígado $(5 \%)$ foram consideradas como aspectos de rejeição, apesar do baixo percentual verificado.

A FIGURA 2 mostra a grande concentração nos valores 8 - gostei muitissimo (51\%), 7-gostei ligeiramente (26\%), e juntamente com a pequena porcentagem dos que gostaram muitíssimo (5\%) e gostei ligeiramente $(5 \%)$ significa que a grande maioria aprovou a preparação. A média estatística também substimou em uma nota a aceitação do bolinho. 
FIGURA 2: Distribuição dos provadores (\%) em função dos valores hedônicos marcados na escala para o bolinho com hidrolisado de carne bovina

\section{PORCENTAGEM}

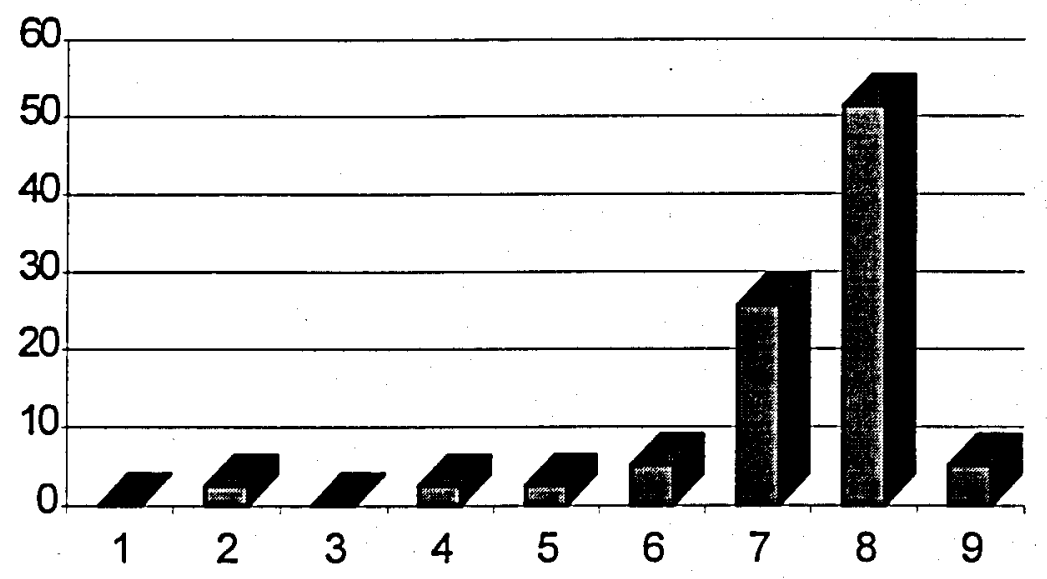

ESCALA HEDÔNCA

Os comentários em relação ao bolinho a textura, odor, aparência foram bem satisfatórios $(17 \%)$, mas ocorreram observações no que diz respeito ao teor excessivo de gordura (9\%) pela fritura. A aceitação do bolinho foi comprovada com as anotações dos provadores que, apesar de serem em número pequeno, houve a manifestação oral, sugerindo servir maiores porções pelo seu sucesso.

A distribuição dos provadores (FIGURA 3) apresentou uma dispersão maior, sendo as maiores no valor 4- desgostei ligeiramente (20\%) e 6-gostei ligeiramente (20\%). Mas observou-se, também, que somando-se as porcentagens das notas $6(20 \%), 7(18 \%), 8((13 \%)$ e $9(3 \%)$ representam mais de $50 \%$ das respostas, mostrando aceitação da preparação. Em relação à análise estatística (TABELA 6) o valor corresponde ao valor entre as duas maiores concentrações constatadas (nota 5 - 10\%). 
FIGURA 3 : Distribuição dos provadores (\%) em função dos valores hedônicos marcados na escala para vitamina com hidrolisado de carne bovina

\section{PORCENTAGEM}

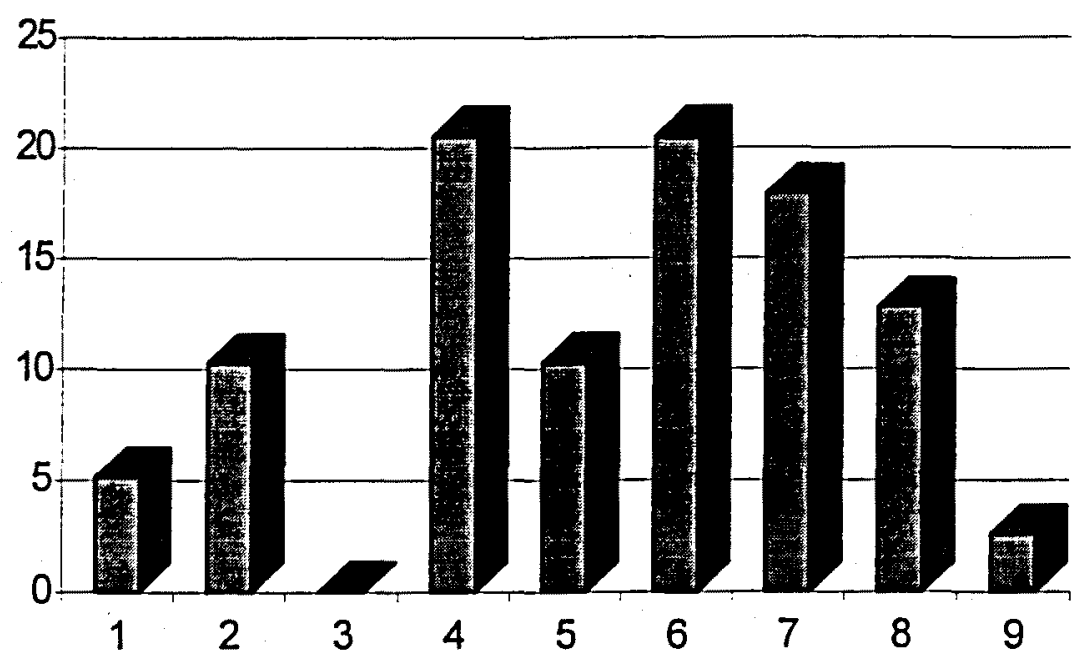

ESCALA HEDÔNCA

A vitamina foi aceita para cor, sabor e consistência (18\%), sabor da mistura de fruta e legumes e presença de resíduos (12\%). Houve rejeição da preparação por alguns degustadores $(5 \%)$, presença excessiva de residuos $(10 \%)$, sabor levemente ácido desagradável( $5 \%)$, ou muito doce (5\%) ou com amargor final indesejável(5\%). Algumas das manifestações foram contraditórias como a presença do resíduo, justificadas estas observações a dispersão das notas.

A maior concentração das notas (FIGURA 4) foi no valor 8 , gostei muito(28\%), seguida pelo valor 7 -gostei moderadamente $(23 \%)$, sendo a maior dispersão acima de 6-gostei ligeiramente (15\%), aproximadamente $60 \%$, demonstrando aceitação da preparação musse. A análise estatística apresenta como valor médio a nota próxima a gostei moderadamente (nota 7), não correspondendo à maior concentração dos valores. 
FIGURA 4 : Distribuição dos provadores (\%) em função dos valores hedônicos marcados na escala para musse com hidrolisado de carne bovina

\section{PORCENTAGEM}

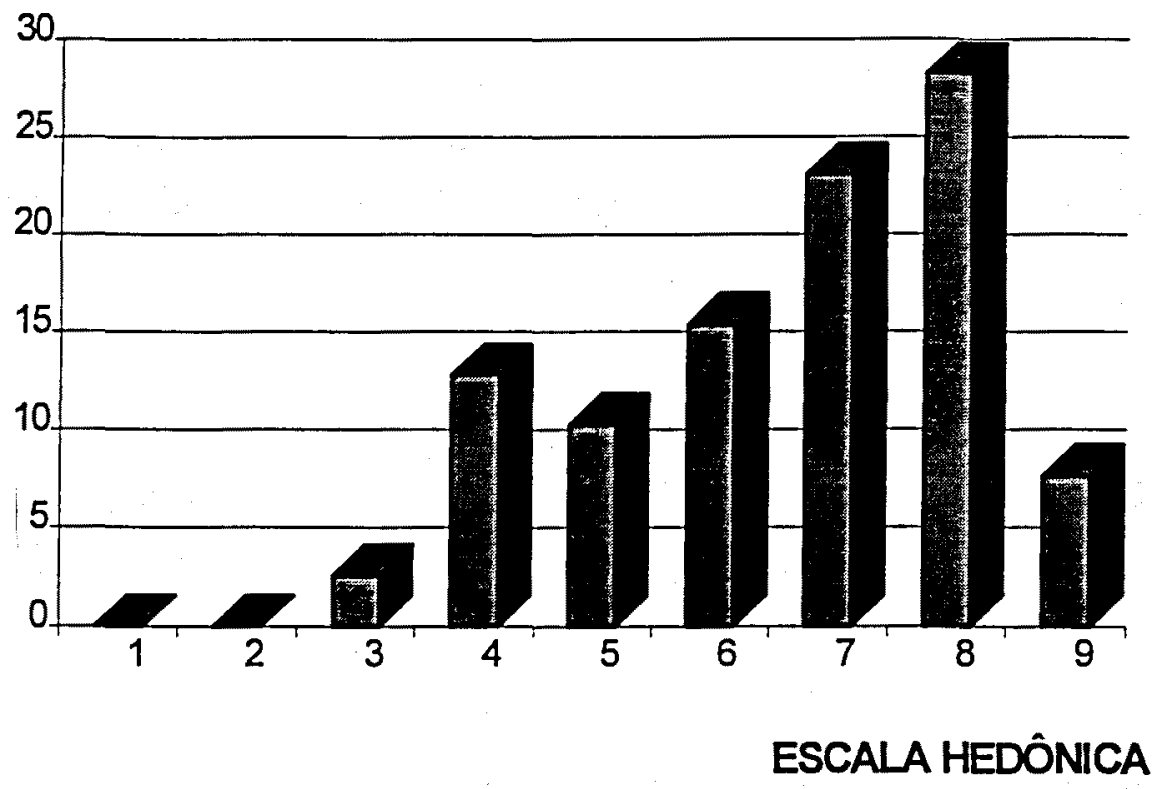

As observações para a musse de mais gostei na ficha de avaliação, foram para a textura, cor e sabor (17\%); menos gostei para sabor doce e consistência $(2,5 \%)$, acidez final $(5 \%)$ e gosto de clara de ovo $(2,5 \%)$.

Levando-se em conta as distribuições apresentadas, as observações na ficha de avaliação e as pequenas porcentagens em relação aos aspectos de rejeição, pode-se dizer que as preparações com hidrolisado de carne bovina obtiveram aceitação satisfatória, pela escala hedônica. $A$ aceitação do produto final poderá ser melhorada se levar em consideração os comentários referidos a cada preparação, como sugerir novas combinações dos legumes na sopa e na vitamina e melhorar o sabor da musse, através de batimento maior talvez supra o sabor de ovo anotado. 


\section{2 - Preparações com hidrolisado de carne de peru :}

O bolinho e a musse foram as preparações com maior média de aceitação, correspondentes na escala hedônica à classificação entre gostei muito e gostei moderadamente. As médias da sopa e da vitamina foram inferiores às outras as duas preparações, entretanto, foram aceitas por grande perta dos provadores (TABELA 7).

TABELA 7: Médias e desvios padrão obtidas em cada preparação com o hidrolisado de carne de peru

\begin{tabular}{lcc}
\hline \multicolumn{1}{c}{ preparação } & média & desvio padrão \\
\hline sopa & & 2.273 \\
bolinho & 5.583 & 0.971 \\
vitamina & 7.833 & 1.997 \\
musse & 5.806 & 1.300 \\
\hline
\end{tabular}

Não sendo apresentada, portanto, rejeição a essas preparações com o hidrolisado de carne de peru. As anotações nas fichas de avaliação foram semelhantes às das preparações com o hidrolisado de carne bovina, exceto quanto à presença do sabor de fígado, que não foi citado em nenhuma delas com esse hidrolisado.

A FIGURA 5 apresenta a distribuiçào da aceitação pelos provadores e nela podemos observar que a maior porcentagem encontra-se na nota $7(28 \%)$ gostei moderadamente, seguida da $8(17 \%)$ - gostei muito. Apesar de apresentar dispersão na aceitação $62 \%$ das respostas estão acima do valor 6 que corresponde na escala hedônica a gostei ligeiramente, confirmando aprovação pelos provadores da preparação. 
FIGURA 5 : Distribuição dos provadores (\%) em função dos valores hedônicos marcados na escala para a sopa com hidrolisado de carne de peru

\section{PORCENTAGEM}

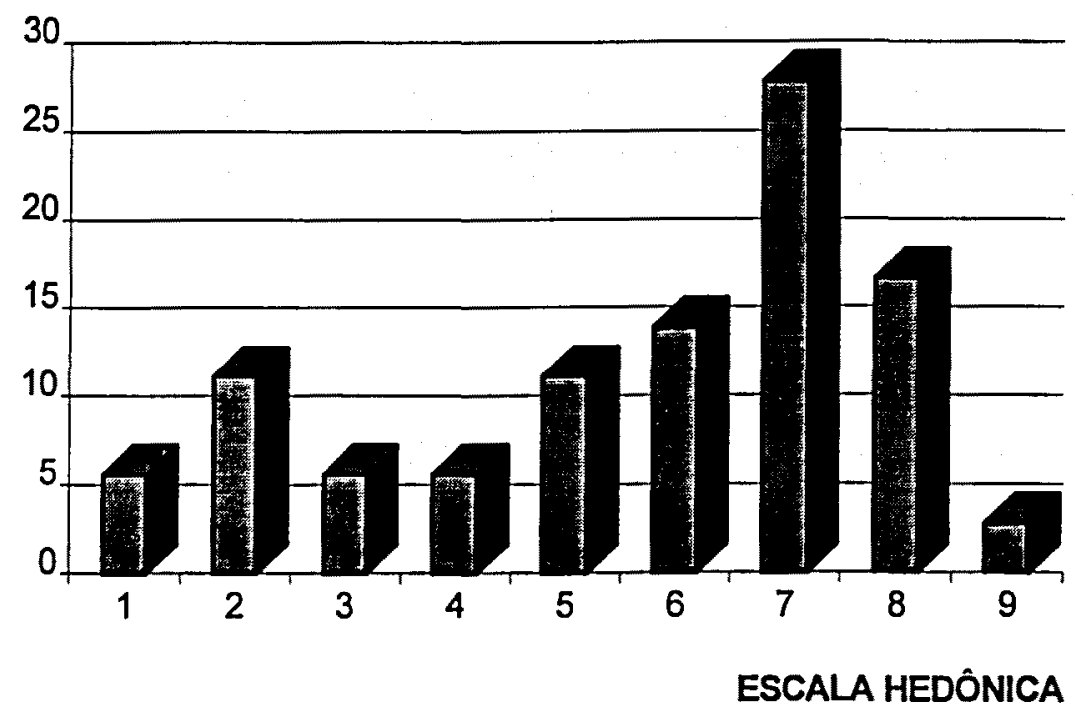

A textura, cor, sabor e tempero da sopa com hidrolisado de peru foram ressaltados como agradáveis e caracteristico da preparação por $30 \%$ dos degustadores; e para 0 aspecto de menos gostei, $3 \%$ fizeram anotaçōes em relação a presença de sabor residual não definido. Em relação a esse sabor residual não souberam identificar, mas constataram como um amargor não desejável

A FIGURA 6 apresenta a distribuição dos provadores em relação à sua aceitação do bolinho com hidrolisado de peru, e pode-se observar a maior porcentagem está no valor 8 - gostei muito (44\%). As outras duas maiores foram $25 \%$ no valor 9 - gostei muitissimo e valor 7 - gostei moderadamente (22\%), apenas $9 \%$ considerou como gostei ligeiramente e nem gostei nem desgostei. Mostrando grande aceitação desse bolinho pelos provadores, e o que está coincidindo com a média obtida pela análise estatistica 
FIGURA 6 : Distribuição dos provadores (\%) em função dos valores hedônicos marcados na escala para o bolinho com hidrolisado de carne peru

\section{POROENTAGEM}

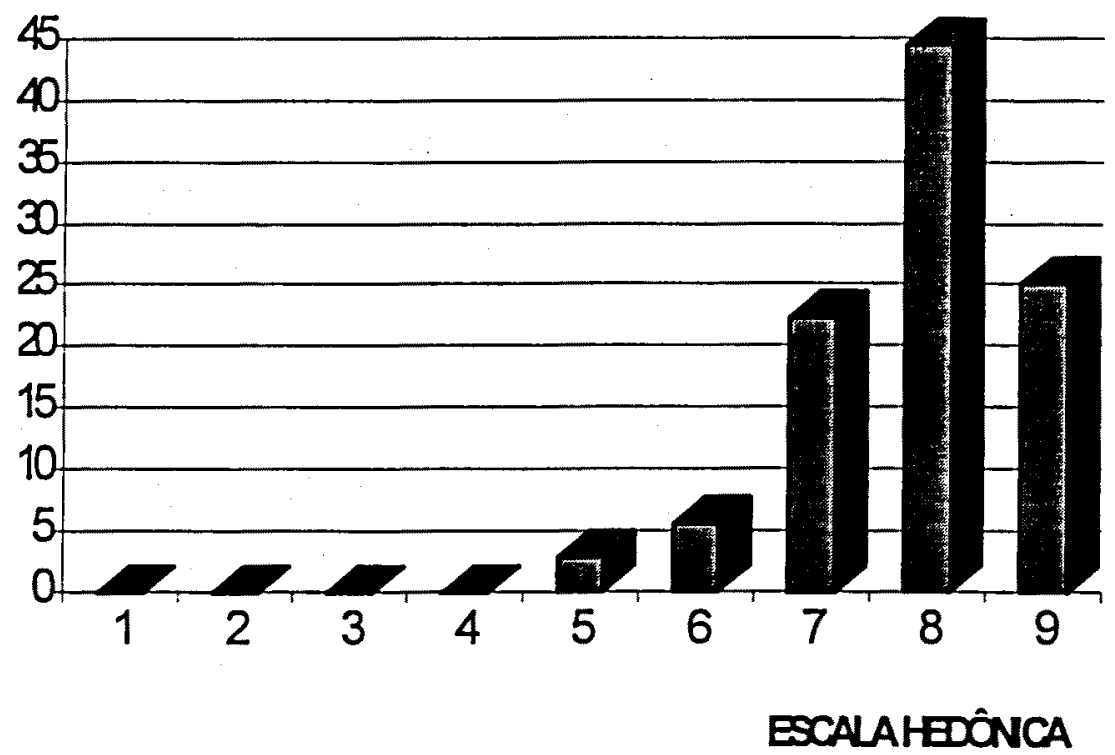

O bolinho teve destaque para os aspectos de consistencia, textura e aparência nas observações de mais gostei $(25 \%)$ e como não gostei a presença de gordura (3\%). O fator gordura apresentado é inerenta à preparação por ser uma fritura de imersão.

A vitamina apresentou também dispersão na sua aceitação (FIGURA 7), mas sendo a maior porcentagem no valor 6 - gostei ligeiramente (28\%), seguida de gostei muito -valor 8 (19\%), e gostei moderadamente - valor 7 (17\%). Juntamente com os $3 \%$ para gostei muitíssimo $67 \%$ dos provadores aceitou essa preparação, enquanto que apenas $33 \%$ apresentou alguma rejeição à vitamina. 
FIGURA 7 : Distribuição dos provadores (\%) em função dos valores hedônicos marcados na escala para vitamina com hidrolisado de carne peru

\section{POROENTAGEM}

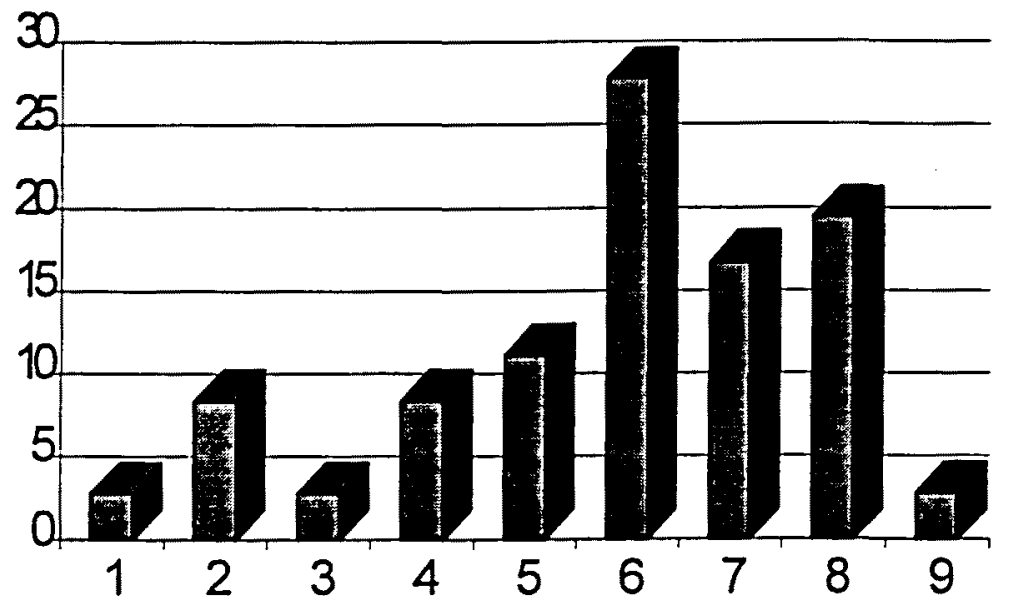

ESCALA HEÔNCA

A vitamina teve $20 \%$ de observaçōes de mais gostei para cor, sabor, consistência e aparência, e para a presença de residuo (10\%), acidez (7\%), doce $(3 \%)$ como observações de menos gostei. Observa-se que embora seja caracteristico da vitamina a presença de porcentagem de resíduo desagradou alguns provadores, e em relação ao sabor as anotações são consequentas às preferências pessoais.

A musse com hidrolisado de peru apresentou como maior porcentagem de aceitação (FIGURA 8 ) o valor 8 - gostei muito (47\%) quase a maioria, mas adicionando as duas outras de maiores valores que foram 7 - gostei ligeiramente (19\%) e 9 - gostei muitissimo (17\%), representam $83 \%$ dos provadores. Com essa distribuição pode-se dizer que houve boa aceitação da musse, e apenas $17 \%$ dos provadores avaliou como desgostei ligeiramente $6 \%$, nem gostei nem desgostei - $8 \%$ e gostei ligeiramente - $3 \%$. 
FIGURA 8 :Distribuição dos provadores (\%) em função dos valores hedônicos marcados na escala para a musse com hidrolisado de carne de peru

\section{PORCENTAGEM}

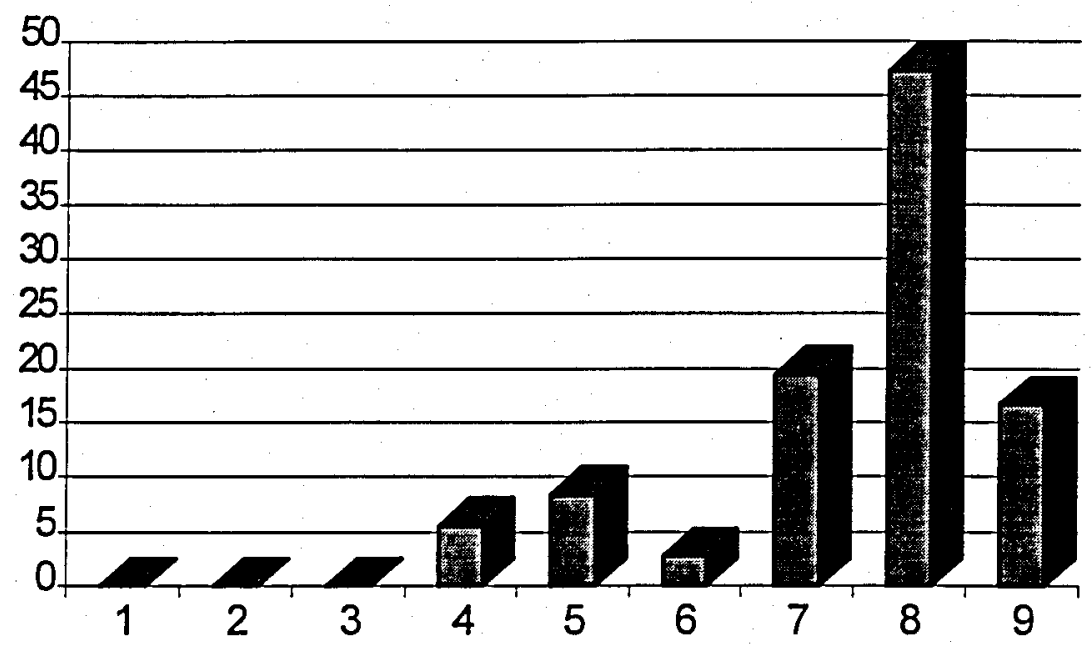

\section{ESCALA HEDÔNCA}

$\mathrm{Na}$ musse, destacaram-se como positivas as características da textura, cor e aeração (15\%) e como negativas, o sabor doce e a consistência (5\%). Características de preferência individual, em relação à intensidade do sabor doce.

As preparações podem ser consideradas como aceitas pelos resultados obtidos e, em especial,a sopa pode ser reavaliada quanto à variação de legumes levando-se em conta as observações feitas na ficha de avaliação, assim como a vitamina pode ser testada com outras frutas e legumes, melhorando sua aceitação.

\section{3 - Preparações com hidrolisado de frango}

A preparação com maior valor médio foi a do bolinho classificando-se como próxima a gostei muito, seguida pela musse - próxima a gostei moderadamente. As outras duas apresentaram médias semelhantes, próximas a gostei ligeiramente(TABELA 8). 
TABELA 8: Médias e desvios padrão obtidos em cada preparação com o hidrolisado de carne de frango

\begin{tabular}{lll}
\hline preparações & média & desvio padrão \\
\hline sopa & 5.840 & 2.298 \\
bolinho & 7.760 & 1.060 \\
vitamina & 5.760 & 2.228 \\
musse & 6860 & 2.466 \\
\hline
\end{tabular}

A FIGURA 9 apresenta a distribuição dos provadores em função da escala hedônica, referente à sopa com hidrolisado de carne de frango. Observa-se que as maiores concentrações estão no valor $7(26 \%)$ correspondente a gostei moderadamente e no valor $8(22 \%)$ gostei muito. Verifica-se, ainda, que do valor $6(16 \%)$ gostei ligeiramente até o $9(4 \%)$ gostei muitíssimo, somados aos valores anteriores totaliza $68 \%$ dos provadores significando aceitação da sopa.

FIGURA 9: Distribuição dos provadores (\%) em função dos valores hedônicos marcados na escala para a sopa com hidrolisado de frango

\section{PORCENTAGEM}

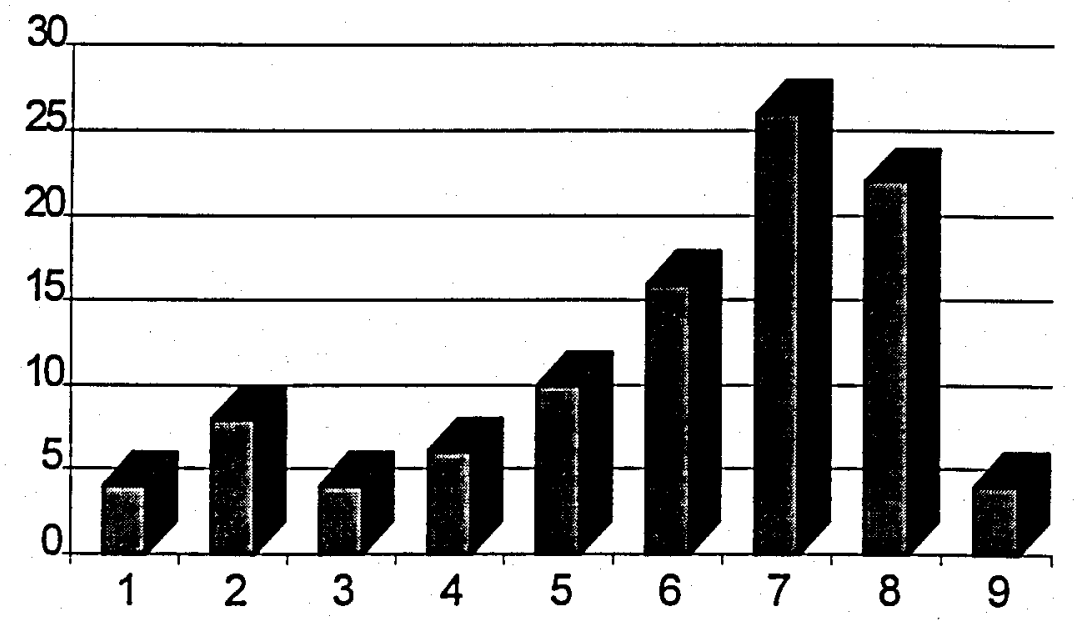

ESCALAHEDONNCA 
As observações feitas são coincidentes com as apresentadas para o hidrolisado bovino, consistência, sabor e tempero agradáveis (25\%),leve sabor residual amargo (5\%), sem, entretanto, observação ao sabor de figado. Não houve referência à coloração indefinida.

A FIGURA 10 mostra que a maior distribuição dos provadores fixou-se no valor $8(56 \%)$, já representando a maioria deles e que os outros valores significativos foram $9(18 \%)$ gostei muitissimo e $7(18 \%)$ gostei moderadamente. Com essa distribuição pode-se ponderar que houve boa aceitação do bolinho

FIGURA 10: Distribuição dos provadores (\%) em função dos valores hedônicos marcados na escala para o bolinho com hidrolisado de frango

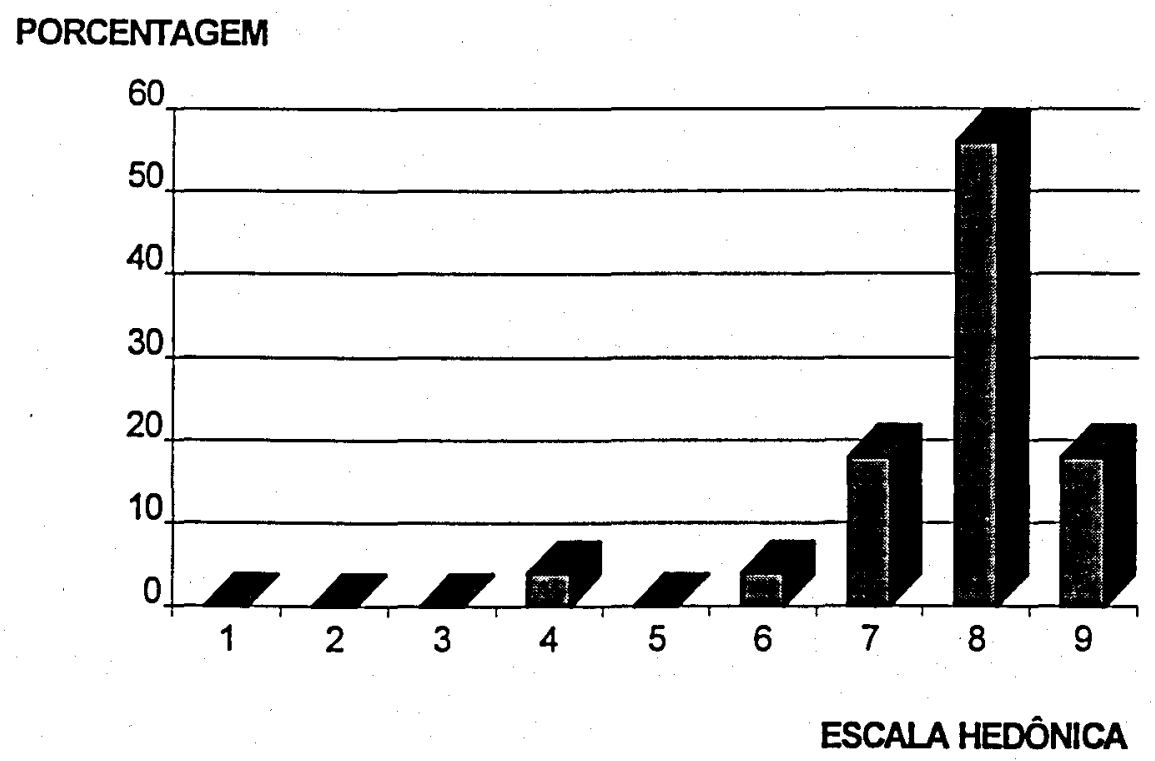

As observações nas fichas de avaliação referem-se à apreciação quanto à textura, aparência, crocância (20\%), e nos aspectos de não gostei a consistência muito macia internamente (5\%). A aceitação do bolinho ficou comprovada tanto pela média estatistica obtida quanto pela distriduição percentual dos provadores e suas, manifestações escritas e verbais.

A distribuição dos provadores apresentada na FIGURA 11 mostra que para a vitamina houve maior dispersão, obtendo valores maiores em ordem decrescente, 7 (30\%) gostei moderadamente, 8 (18\%) gostei muito e 6 (14\%) gostei ligeiramente. A soma desses três é $62 \%$, portanto, mais da metade dos 
provadores aceitou a preparação, apesar das apreciações de desgostei (30\%) não havendo constatação de nenhum desgostei muitíssimo. Pela análise estatística o valor obtido ficou próximo ao de gostei ligeiramente, substimando a aceitação justamente pela dispersão das notas dos provadores.

FIGURA 11 : Distribuição dos provadores (\%) em função dos valores hedônicos marcados na escala para vitamina com hidrolisado de frango

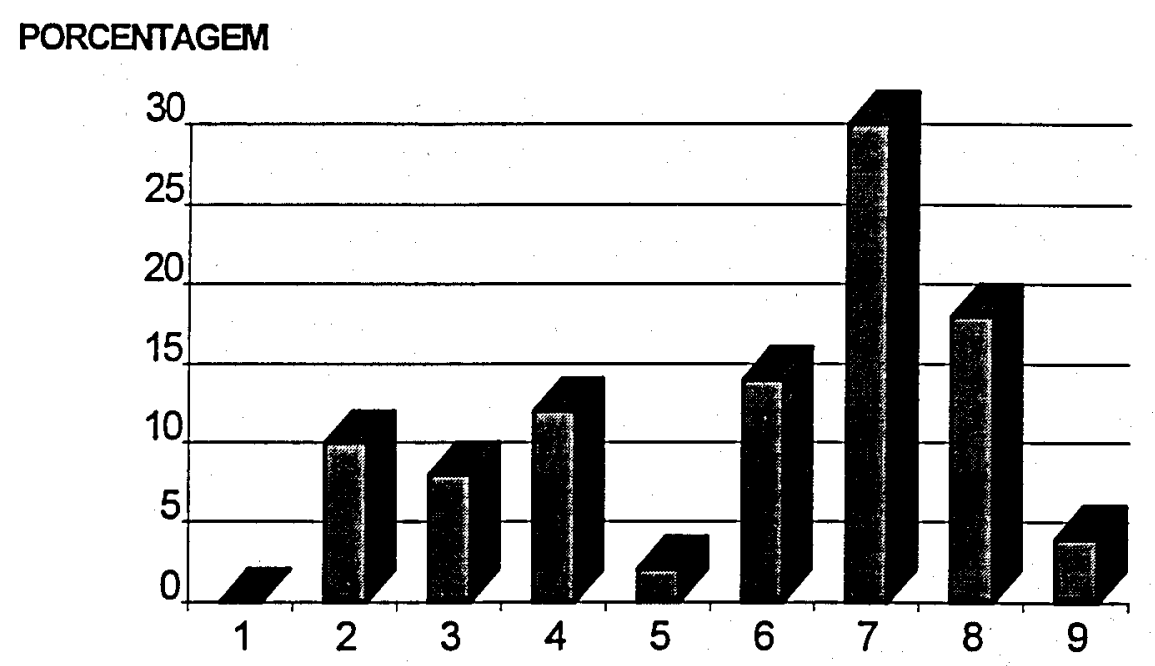

ESCALA HEDÔNICA

Pelas observações das fichas constatou-se que houve aceitação em relação à cor, sabor e consistência (20\%), mistura de fruta e legumes, e presença de resíduos (10\%), mas alguns não gostaram do sabor ácido $(5 \%)$ excesso de resíduos (8\%) e amargor final (2\%). No que diz respeito aos resíduos é caracteristica da preparação, mas, como ressaltado, pode-se, através de maior tempo de liquefação melhorar este aspecto, tornando-a mais cremosa, com menos granulação e adicionar outra fruta ou legume para eliminar ou minimizar a acidez.

A distribuição apresentada na FIGURA 12 mostra a grande concentração dos valores 6 a $9(85 \%)$ de gostei ligeiramente a gostei muitíssimo, constatando a boa aceitação do bolinho pelos provadores (maior proporção em gostei muito). As menores porcentagens encontradas entre os valores da escala de 1 desgostei muitíssimo a 5 nem gostei nem desgostei, devem ser relativas às 
anotações dos degustadores sobre o sabor pouco acentuado (5\%). Pelas observações, a adição de mais suco equilibrando o sabor doce, poderia suprir esta caracteristica apontada como indesejável.

FIGURA 12: Distribuição dos provadores (\%) em função dos valores hedônicos marcados na escala para a muse com hidrolisado de peru

\section{PORCENTAGEM}

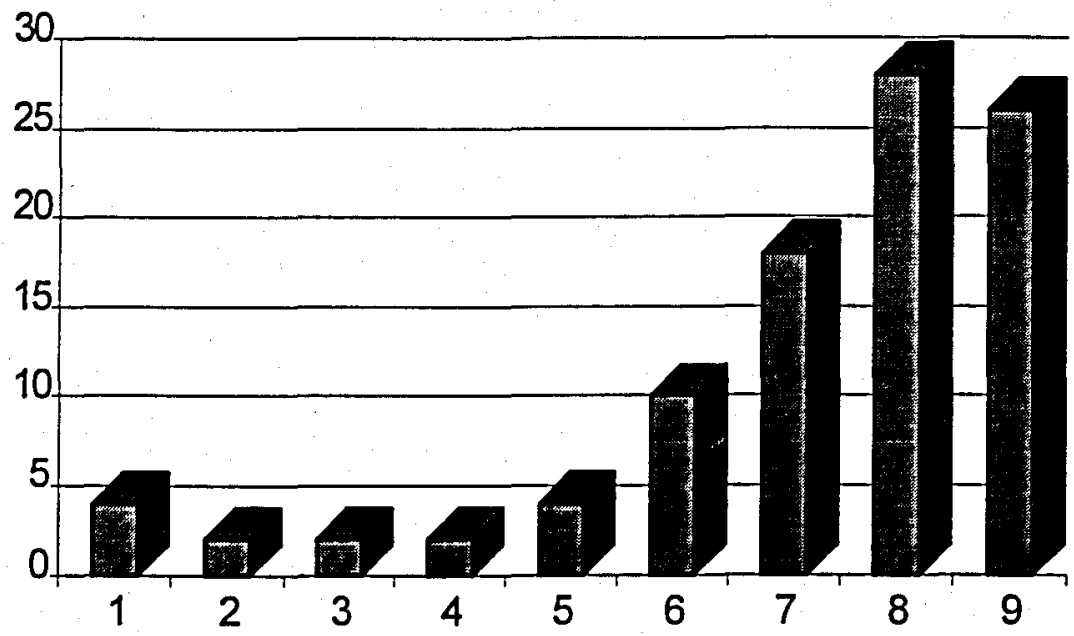

ESCALA HEDÔNCA

Observa-se, assim, que as preparações com hidrolisado de carne de frango não apresentaram rejeição. Como o ocorrido para os outros hidrolisados, algumas pequenas modificações podem melhorar a sua aceitação. Nota-se que os resultados para o hidrolisado de frango e o de peru foram coincidentes em relação à cor, consistência e sabor da sopa, do bolinho e da musse,.e para a vitamina não apareceram anotações de não gostei para o sabor .

Considerando as características de cada hidrolisado e constatada sua aceitação, fêz-se análise estatística comparativa de cada preparação, para verificar se havia ou não diferença entre os diferentes hidrolisados. As TABELAS 9, 10, 11 e 12. mostram as médias obtidas na análise estatística, com base nos valores atribuidos pelos degustadores na escala hedônica. As FIGURAS $13,14,15$ e 16 apresentam a distribuição percentual dos degustadores em função dos valores,marcados na escala. 
TABELA 9 : Médias e desvios padrão das sopas preparadas com os três hidrolisados

\begin{tabular}{lll}
\hline Hidrolisados & Média & Desvio padrão \\
\hline bovino & $6.256^{\mathrm{a}}$ & 1.916 \\
peru & $5.583^{\mathrm{a}}$ & 2.273 \\
frango & $5.840^{\mathrm{a}}$ & 2.298 \\
& & \\
\hline
\end{tabular}

a Mesmas letras significam médias estatiticamente iguais

Embora a sopa com hidrolisado de carne bovina tenha obtido maior média (TABELA 9), nã̉o é estatisticamente diferente daquela das sopas com os demais hidrolisados, sendo classificada pelos degustadores, próximo agostei ligeiramente. Os resultados levam a concluir que o tipo de hidrolisado pouco influenciou nessa preparação.

FIGURA 13 : Distribuição dos provadores (\%) em função dos valores hedônicos marcados na escala para sopas com os hidrolisados de carne bovina, de peru e de frango

\section{PORCENTAGEM}

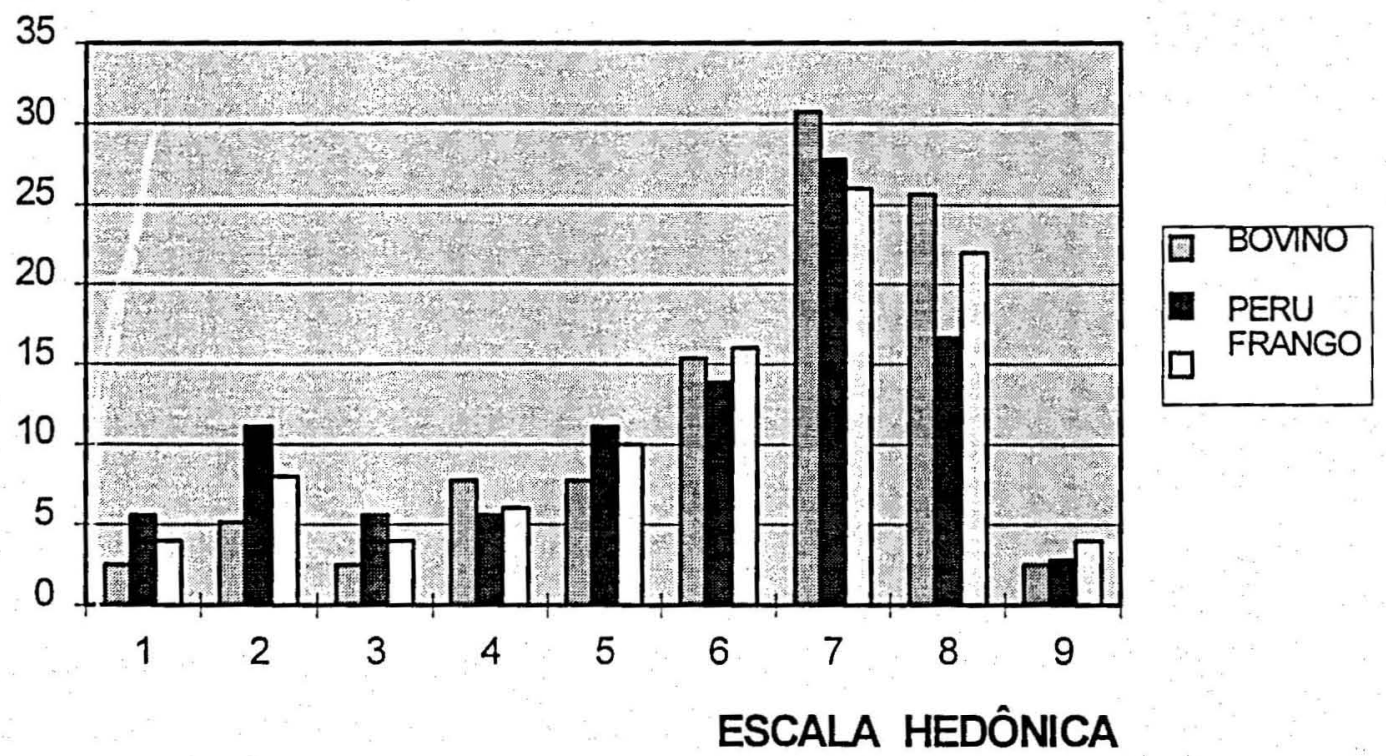


A FIGURA 13 mostra a distribuição dos provadores (\%) relativa às sopas preparadas com os três tipos de hidrolisado, onde se pode observar que as maiores concentrações estão nos valores 7 gostei moderadamente, 8 gostei muito e 6 gostei ligeiramente. Apesar de verificarmos que os três hidrolisados estão concentrados semelhantemente, nota-se que a porcentagem para a de bovino é ligeiramente superior, justificando sua média pouco maior.

TABELA 10: Médias e desvios padrão dos bolinhos preparados com os três hidrolisados

\begin{tabular}{lcc}
\hline Hidrolisados & Média & Desvio padrão \\
\hline bovino & $6.923^{\mathrm{a}}$ & 2.095 \\
peru & $7.833^{\mathrm{b}}$ & 0.971 \\
frango & $7.760^{\mathrm{b}}$ & 1.061 \\
\hline
\end{tabular}

a,b Mesmas letras significam médias estatísticamente iguais

A preparação bolinho não apresentou diferença estatistica entre os hidrolisados de peru e de frango, mas diferiu daquela com hidrolisado de bovino (TABELA 10). Na escala hedônica, o bolinho à base dos hidrolisados de peru e de frango classificou-se como próximo a gostei muito e o de bovino, a gostei moderadamente. Os hidrolisados de carne de peru e de frango foram os que apresentaram melhor resultado neste tipo de preparo, não sendo identificado, porém, fator determinante para essa diferença com o de bovino, sendo referida apenas como fator não desejável o teor de gordura que persistiu no bolinho.

$\mathrm{Na}$ distribuição da porcentagem de aceitação dos provadores, apresentada na FIGURA 14, observa-se que a maior concentração está no valor 8 gostei muito, semelhantemente para os três hidrolisados, diferenciando-se para o de bovino os valores 7 , pouco maior, e 9 , pouco menor justificar esse fato da diferença estatistica. Como anteriormente citado o bolinho preparado com hidrolisado de carne bovina pode ser melhorado em sua fritura, atingindo porcentagens maiores de aceitação, não apresentando assim diferença em sua utilização quando comparado aos com os outros dois hidrolisados 
FIGURA 14: Distribuição dos provadores (\%) em função dos valores hedônicos marcados na escala para os bolinhos com os hidrolisados de carne bovina, de peru e de frango

\section{PORCENTAGEM}

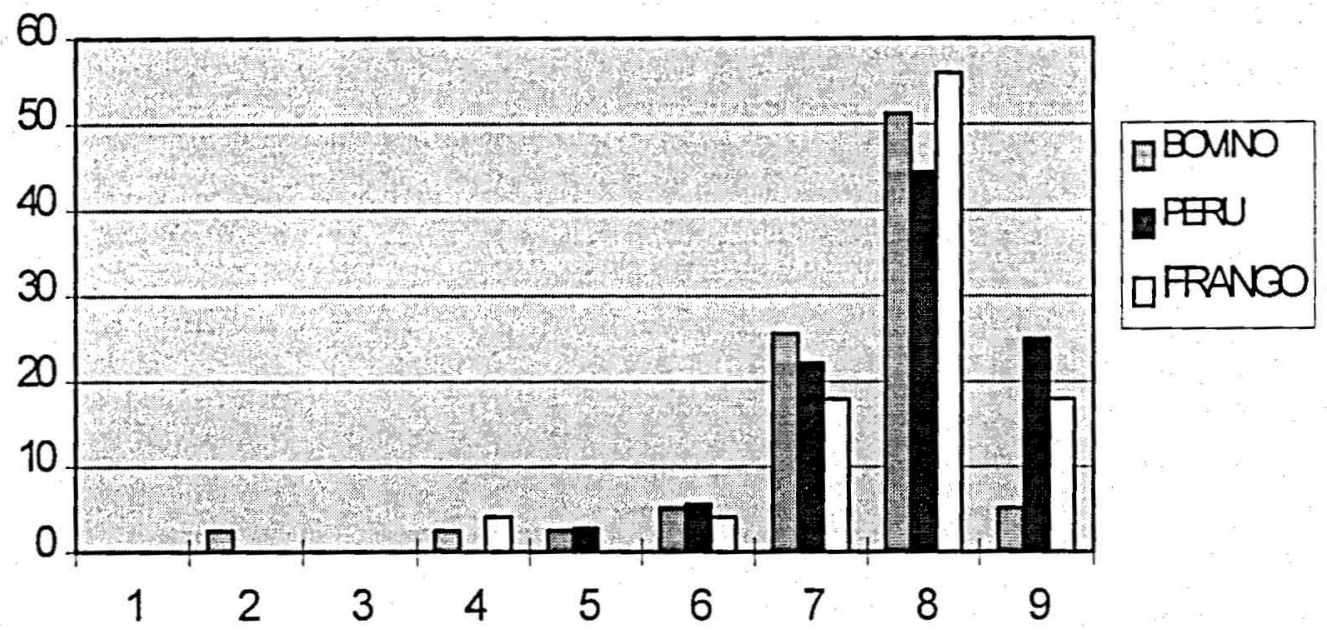

\section{ESCALAHEDÔNCA}

As vitaminas não apresentaram diferença estatisticamente significativa sendo as médias daquelas preparadas com hidrolisados de peru e frango pouco maiores (TABELA 11), o que, na escala hedônica, significa próximo a gostei ligeiramente e nem gostei nem desgostei para a de hidrolisado bovino. Pelas diferenças obtidas entre as médias, observa-se que os hidrolisados pouco influenciaram neste tipo de preparação .

TABELA 11 : Médias e desvios padrão das vitaminas preparadas com os três hidrolisados

\begin{tabular}{lll}
\hline Hidrolisados & Média & Desvio padrão \\
\hline bovino & $5.333 \mathrm{a}$ & 2.107 \\
peru & $5.806 \mathrm{a}$ & 1.997 \\
frango & $5.760 \mathrm{a}$ & 2.227 \\
\hline
\end{tabular}

a mesmas letras significam médias estatísticamente iguais 
Observa-se na FIGURA 15 dispersão entre os percentuais da vitamina preparada com os três tipos de hidrolisados. Destaca-se a soma das porcentagens dos valores 6 a 9 foram as seguintes bovina-54, peru - 66 frango -6 comprovando a aceitação semelhante das três. Apenas a com hidrolisado bovino apresentou no valor 4 desgostei ligeiramente, maior porcentagem do que as outras e, igual ao do valor $6(20 \%)$ fator esse que leva a redução da sua média estatística. Em relação às vitaminas com hidrolisado bovino deve-se aperfeiçoar o aspecto sabor para ser melhorada sua aceitação.

FIGURA 15: Distribuição dos provadores (\%) em função dos valores hedônicos marcados na escala para vitamina com hidrolisados de carne bovina, de peru e de frango

\section{PCROENTAGEM}

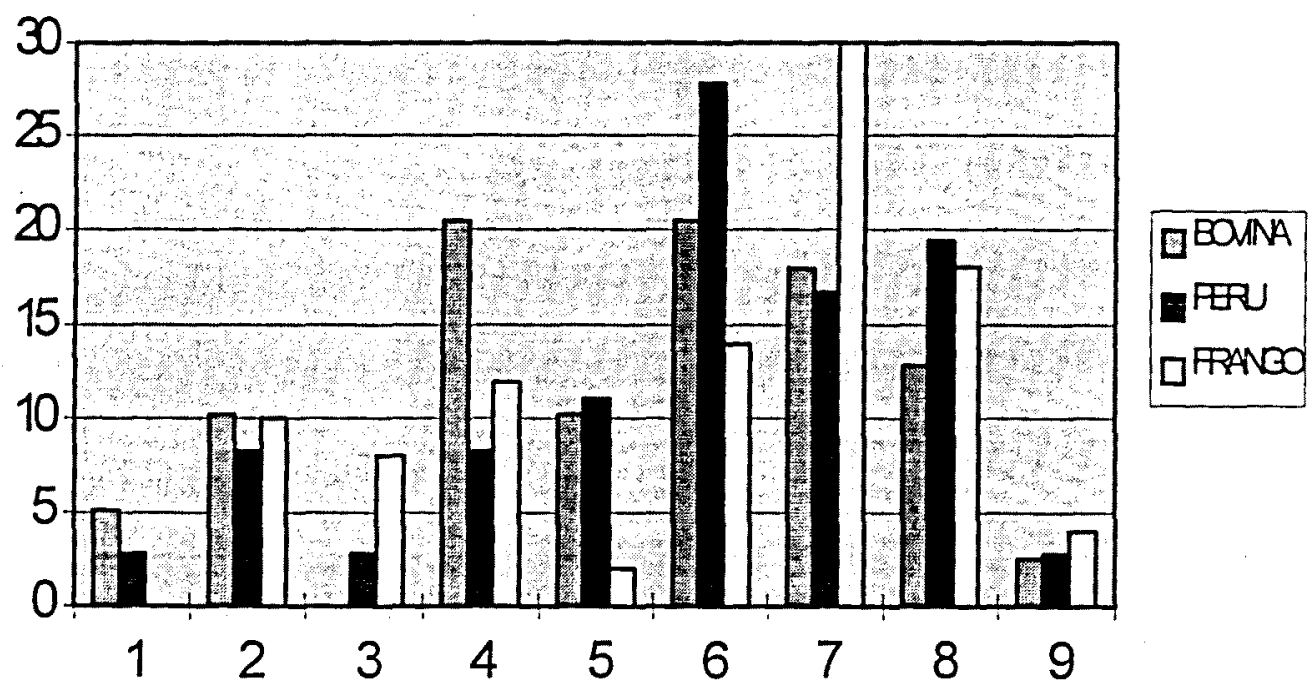

ESCLAHEDÔNCA 
Não foram observadas médias estatisticamente diferentes entre a musse com os três hidrolisados, sendo que a de peru foi um pouco superior (TABELA 12). Mas as três, pela avaliação na escala hedônica, estão próximas ao grau gostei moderadamente. Nota-se, entretanto, que a musse com o hidrolisado de carne de peru apresentou resultado ligeiramente superior em relação àquelas com os outros dois tipos de hidrolisado, não significando porém diferença na utilização indistinta dos três na musse.

TABELA 12 : Médias e desvios padrão da musse preparada com os três hidrolisados

\begin{tabular}{llc}
\hline Hidrolisados & Média & Desvio padrão \\
\hline bovino & $6.590 \mathrm{a}$ & 1.618 \\
peru & $7.444 \mathrm{a}$ & 1.362 \\
frango & $6.860 \mathrm{a}$ & 2.466 \\
& & \\
\hline
\end{tabular}

* a Mesmas letras significam médias estatisticamente iguais

A apresentação das porcentagens de distribuição dos provadores (FIGURA 16) mostra que houve dispersão desta com hidrolisado bovino dos valores 4desgostei ligeiramentea 9 - gostei muitissimo, mas sendo sua maior concentração entre os valores 6 e 9. (73\%), enquanto que a com peru e com frango apareceram em maior concentração apenas acima do valor 6 . Apesar desta dispersão com o de bovino o total de aceitação pelos provadores acima do valor 6 gostei ligeiramente não foram muito diferentes $-73 \%$ bovino, 85 peru e $82 \%$ franyo. Como resultado observamos que a aceitação do peru em gostei muito destaca-se dai seu valor maior resultante na análise estatística (TABELA 12), mas nểo diferentes em relação à escala hedônica próximos.ao grau gostei moderadamente, 
FIGURA 16: Distribuição dos provadores (\%) em função dos valores hedônicos marcados na escala para as musses com os hidrolisados de carne bovina, de peru e de frango

\section{POROANIAGM}

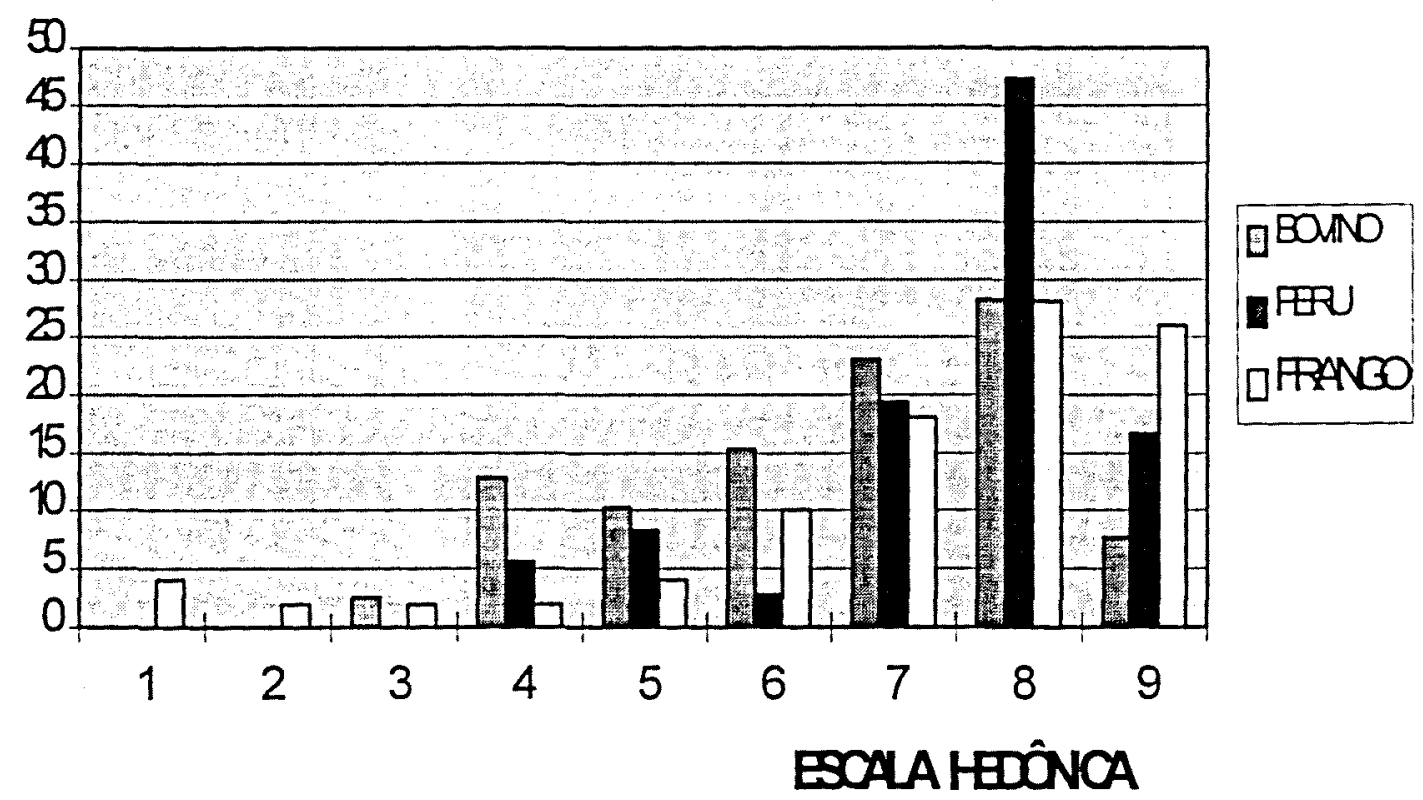

Em todas as análises, verifica-se que a média acima de sete foi obtida pelo bolinho com hidrolisado de peru e de frango e pela musse com hidrolisado de peru. De fato, foram as preparações de maior aceitação, como indicam as fichas de avaliação. Nas preparações com hidrolisado de carne bovina foi notado sabor férrico, não esperado de fígado, o que não ocorreu para os hidrolisados de frango e peru que pouco afetaram o sabor e a cor.

Para detectar se a variabilidade das respostas poderia ter sido influenciada pela idade no que diz respeito às características específicas das preparações, foram computadas as anotaçōes mais e menos gostei da ficha de avaliação, segundo as as três faixas etárias : menor de 20 , de 20 a 40 e maior de 40 anos. 
Das observações de mais gostei para a sopa, o sabor salgado foi citado pelas faixas etárias abaixo de 20 anos,e o tempero, no grupo acima de 40 anos. Para o menos gostei, o sabor salgado aparece nas duas faixas etárias acima de 20 anos, o que vem mostrar a preferência pelo sabor salgado no grupo abaixo de 20 anos e o conjunto de tempero pelos individuos acima dessa idade.

Para a sopa, em relação ao grau de gostar, na faixa etária superior a 40 anos $49 \%$ dos que se manifestaram assinalou acima de gostei moderadamente, enquanto que no grupo abaixo de 20 anos foi de $45 \%$ e entre aquele de 20 a 40 anos, $41 \%$. Nos demais graus da escala, a distribuição percentual foi semelhante para as três faixas. Essas proporções mostram maior aceitação da sopa pelos indivíduos acima de 40 anos.

As observações de mais gostei para o bolinho com os três hidrolisados foram o tempero entre os individuos acima de 20 anos e menos gostei para a consistência interna de bolinho (mole) nesta mesma faixa etária. Nos três grupos, $70 \%$ das respostas estão acima de 7 (gostei moderadamente). 0 restante da amostra distribuiu-se semelhantemente pelas demais graduações. Esses resultados mostram que a boa aceitação do bolinho independe da idade do indivíduo .

Para a vitamina, na faixa de 20 a 40 anos, as observações de mais gostei foram para a presença de resíduo, o que também foi citado por menor número (5\%) como menos gostei. Nas outras duas faixas etárias, o resíduo foi considerado como indesejável. O maior número de pontuações acima de 7 foi observado na faixa superior a 40 anos (60\%); entre 20 e 40 , em apenas $40 \%$. Para o valor acima de 5 (nem gostei nem desgostei), os resultados foram $78 \%$ para o grupo abaixo de 20 anos, $67 \%$ entre 20 e 40 e $80 \%$ para o grupo superior a 40 anos. Esses dados mostram, assim, que a vitamina tem aceitação variada entre os individuos menores de 40 anos e maior aceitação entre aqueles acima dessa idade.

Com referência à musse, as observações feitas na ficha de avaliação foram uniformes pelas diferentes faixas etárias no que diz respeito ao mais gostei, mas os degustadores abaixo de 40 anos anotaram como menos gostei a presença de sabor forte. Na distribuição de pontos acima de 7, enquadraram- 
se $88 \%$ dos menores de $20 ; 71 \%$ entre 20 a 40 e $83 \%$ maiores de 40 anos. Valor abaixo de 5 verificou-se em apenas $10 \%$ dos individuos de 20 a 40 anos e em $17 \%$ para os maiores de 40 . Nota-se, assim que a musse tem boa aceitação em todas as faixas etárias.

Conclui-se que, pelos resultados obtidos, as preparações selecionadas e modificadas, com preferências segundo as faixas etárias, foram aceitas. As preparações, apresentando técnicas de fácil elaboração das receitas, podem ser aperfeiçoadas segundo a preferência e gosto do grupo, pois os resultados mostraram aceitação satisfatória, o que possibilita seu emprego em alimentação especial. Os hidrolisados podem ser aplicados nas mais diversas preparações, mas é necessário o conhecimento de suas características, tanto sensoriais quanto químico-físicas, para manutenção, no produto final, do sabor, textura e aparência da preparação original . 
V - CONCLUSÕES 


\section{$V$ - CONCLUSÕES}

- Os hidrolisados dos três tipos de carne apresentam leve sabor amargo residual, entretanto nas preparações esse aspecto é mascarado pela combinação dos ingredientes, porém com o hidrolisado bovino ainda se nota alguma intensidade do sabor

- Os hidrolisados de carne são líquidos que podem ser utilizados em diversas preparações, melhorando seu valor nutritivo e o aproveitamento da proteina pelo organismo, em virtude da forma como esta se encontra.

- A utilização do hidrolisado de carne bovina provoca modificações na cor e sabor da sopa, da musse e do bolinho, enquanto o hidrolisado das outras carnes não influenciam esses aspectos, efeito que pode ser dissimulado através da combinação de diferentes ingredientes. Essa alteração da cor é provocada por ser a carne bovina rica em pigmento contendo ferro.

- A substituição de líquidos pelos hidrolisados de carne em preparações requer seleção adequada de receitas e de seus ingredientes e repetições dos experimentos para obtenção de produtos que sejam satisfatoriamente aceitos.

- O conhecimento das características sensoriais e físico-químicas é de fundamental importância na obtenção de produto satisfatório que apresente qualidade, sabor, textura e aparência semelhantes à preparação original.

- A presença da vitamina $C$, em decorrência do abacaxi no hidrolisado, pode favorecer a absorção, pelo organismo, do ferro, contido nas preparações.

- O emprego do hidrolisado é vantajoso por ser fonte de proteína, na forma cindida, melhorando o valor nutritivo da preparação, com aumento do teor em alguns minerais e vitaminas.

- Os resultados da análise sensorial mostraram que as preparações com hidrolisado de carne de peru e de frango foram as de melhor aceitação. 
- A análise sensorial constituiu instrumento eficiente para informações importantes que reforçam a possibilidade da substituição de ingredientes liquidos em receitas tradicionais e colaborar parao melhor direcionamento das preparações . 
VI - CONSIDERAÇÕES FINAIS 


\section{VI - CONSIDERAÇÕES FINAIS}

- O hidrolisado de carnes constitui recurso que, por suas caracteristicas nutricionais, pode ser utilizado com as mais diversas finalidades, desde dietas especiais, suplementação alimentar destinada a grupos especificos da população, até em alimentação parenteral.

- A técnica proposta para obtenção do hidrolisado de carne é simples e de custo reduzido por utilizar alimentos encontrados o ano inteiro, acessivel, portanto, ao uso por diversos grupos da população que necessitam de produto com maior valor nutritivo e com melhor absorção de proteínas.

- A necessidade de se utilizar, quanto mais rapidamente, alimentação por via oral para recuperação de todo o sistema digestivo, após uso do recurso enteral, faz do hidrolisado opção de custo reduzido e de grande versatilidade na adaptação das mais diversas preparações, suprindo a lacuna da transição dos alimentos líquidos até sólidos.

- Há necessidade da continuidade de experimentos na elaboração de preparações de custo reduzido, facilidade de preparo em nivel doméstico para utilização em alimentação enteral, parenteral, suplementação alimentar como recurso em saúde pública. 
VII - REFERÊNCIAS BIBLIOGRÁFICAS 


\section{VII - REFERÊNCIAS BIBLIOGRÁFICAS}

1 - ACHINEWHU,S.C. e HART,A.D. Effect of processing and storage on the ascorbic acid (vitamin $C$ ) contend of some pineapple varietes grown in the Rivers State of Nigeria Plant Foods for Human Nutrition, 46(4): 335 $-7,1994$.

2- ADIBI, S.A.; KIM, Y.S. Peptide absorption and hydrolysis In: Jonhson,L.R. Physiology of the gastrointestinal tract , New York, Raven Press, 1981: p.1073-1122 .

3- AGGETT,P.J.; HASCHKE, F.; HEINE, W.; HERNELL, O.; KOLETZOKO,B.; REY,J; RUBINO,A.; SCHOCH,G.; SENTERRE, J.; STROBEL,S. ; TORMO,R. Comment on antigen : reduced infant formulae Acta Paed, $\underline{82}$ : 314-9, 1993.

4 - ALPERS, D.H. Digestion and absorption of carbohydrates and protein In: Jonhson, L. R. Physiology of the gastrointestinal tract, $2^{\circ}$ ed., New York, Raven Press, 1978. p. 1469-87.

5 - ANDERSON, L.; DIBBLE, M.V.; TURKKI, P.R.; MITCHELL, H.S.; RYNBERGEN, H.J. Nutrição 170 ed. Rio de Janeiro, Ed. Guanabara, 1988. p.147-77: Utilizaçào de nutrientes: digestão, absorção e metabc.lismo

6 - ASAKURA, Y. Hidrólise de proteinas da carne bovina pela ação da papaina, bromelina e ficina São Paulo , 1982 [ Disertação de Mestrado Faculdade de Ciências Farmacêuticas - USP ].

7 - ASGHAR,A.; TORRES,E.; GRAY,J.I. e PEARSON,A.M. Effect of salt on myciglobin derivatives in the sarcoplasmatic extract from pre and post rigor beef in the presence or absence of mitochondria and microsomes Meat Science, 27: 197 - 209, 1990. 
8 - BARUFFALDI, R. ; COLOMBO, A.J.;SCHUCH,R.; GIOIELLI, L.A. Ação de enzimas vegetais proteolíticas sobre a carne An. Farm. Quim. S. Paulo. 21:81-4, 1981.

9 - BARUFFALDI, R.; COLOMBO, A.J.; FONTINELE, E.M.C.; RAMOS, O.H.R.; BAUCH,T.;WASZYK, A.H. SCHUCH, R. Influência da ação das enzimas vegetais proteoliticas sobre a carne Rev. Farm. Bioquim. Univ. S. Paulo, 13 :63-74, 1975.

10 - BLYER,E.G. ; DYER,W.J.A. Rapid method of total lipid extraction Can. J. Biochem. Physiol., 37: 911-17, 1959.

11 - BURINI, R.C.; CAMPANA, A.D. Digestão, absorção, circulação e utilização de nutrientes In: Riella, M.C. Suporte nutricional, parenteral e enteral, Rio de Janeiro, Ed. Guanabara, 1985 p.162-90.

12 - CAMPANA, A.D. Digestão, absorção e utilização de nutrientes. In: Oliveira,J.E.D.; Santos,A.C. ; Wilson,E.D. Nutrição básica . São Paulo, Ed. Sarvier, 1982. p.67-77.

13 - CHEFTEL, J.C. ; CUQ, J.L. ; LORIENT, D. : Protéines alimentaires . Paris Technique et Documentation - Lavoisier, 1985, p. 35-43: Dénaturation des protéines.

14 - DONZELLI, f. ; DALT,L. ; SCHIAVONA,A.;BARALDI,E. ; MURARO,M. Clinical experience whith a hydrolysed soy formula in infants with protracted enteritis and atopic eczema Pediatr. Med. Chir. 12: 71 9,1990 .

15 - FERREIRA, A.B.H. Novo dicionário da língua portuguesa Rio de Janeiro, Ed Nova Fronteira, 1986. .

16 - FOX, P.F.; MORRISSEY, P.A. ; MULVIHLL, D.M. Chemical and enzymatic modification of food proteins In: Hudson, B.F.J. Developments in food proteins -1 London, Applied Science Publ., 1982. p 1 - 60.

17 - FROKJAER, S. Use of hydrolysate for protein supplementation Food Technol, 48 (10) : 86-8, 1994. 
18 - FUNDAÇÃO IBGE Tabelas de composição de alimentos : Rio de Janeiro, 1985. ( estudo Nacional da Despesa Familiar, v.3).

19 - GALL, H.; KALVERRAM, K.; FORCK, G.; STERRY, W. Kiwi fruit allergy: a new birch pollen-associeted food allergy J.Allergy Clin. Immunol., 94: 70-6, 1994.

20 - HALLBERG,L.; BRUNE,M.;ROSSANDER,L. Effect of ascorbic acid on iron absorptions from different types of meals. Hum.Nutr.:Appl.Nutr. 40A: 97-113,1986.

21 - HAZTMAN,L. ; LAGO,R.C.A. Rapid preparation of fatty acids methyl ester Labor.Pract., 22: 475-76, 1973.

22 - HORWITZ,W. Official methods of analysis of the Association Official Analytical Chemists $13^{\circ}$ edição. Washington, Ed. AOAC, 1980.

23- INTERNATIONAL COMMISSION ON MICROBIOLOGICAL SPECIFICATIONS FOR FOODS Ecologia microbiana de los alimentos . Zaragoza, Ed.Acribia / ICMSF, 1980. v.1, p. 96-117:pH y acidez.

24 - INSTITUTO ADOLFO LUTZ . Normas analíticas do Instituto Adolfo Lutz.. $3^{\circ}$ ed. São Paulo, 1985. v1.

25 - INSTITUTO DE TECNOLOGIA DE ALIMENTOS (ITAL). Abacaxi Campinas. 1978 (Série Frutas Tropicais, 21) p. 90 - 3.

26 - JULLA,B. Qualités nutritionelles et organoleptiques des viandes bovines Cah. Nutr. Dièt., 23(1): 27 - 33, 1988.

27 - KABIR, I.; SPEELMAN, P. ; ISLAM, A. Systemic allergic reaction and diarrhoea after pineapple ingestion Trop Geogr Med, 45 : 77-9, 1993.

28- KING, J.R. ; PABLO, S. Perdas de vitaminas durante al processamiento de los alimentos. Rev. Chil. Nutr. 5: $143-52,1987$. 
29- LAHL, W.J. ; BRAUN, S.D. Enzymatic production of protein hydrolysates for food use. Food Technol, 48 (10) : 68-71, 1994.

30 - LAJOLO, F.M.; SANTOS, A.C.; WILSON, E.D. Proteínas e aminoácidos. In: Oliveira,J.E.D.; Santos,A.C. ; Wilson,E.D. Nutrição básica . São Paulo, Ed. Sarvier, 1982. p.29-65

31 - LAMOUNIER, J.A. Caracterização bioquimica e nutricional de um hidrolisado de farinha de carne para uso em nutrição enteral. Belo Horizonte , 1984 [Dissertação de Mestrado - Instituto de Ciências Biológicas da Universidade Federal de Minas Gerais ].

32 - LIVINGSTON, D.J. e BROWN,W.D. The chemistry of mioglobin and its reactions. Food Technol:244-52, may, 1981

33 - MAHMOUD, M.I. Physicochemical and functional properties of protein hydrolysates in nutritional products Food Technol, 48 (10):8995,1994 .

34 - MALLET,E. \& HENOCQ, A. Long term prevention of allergic diseases by using protein hydrolysate formula in at risk infants $\underline{J}$ Pediatr.,121 95 $100,1992$.

35 - MATHEUS, D.M. ; ADIBI, S.A. Peptide absorption Gastroenteroogy, 71: $151-61,1976$.

36 - MILLA, P.J. The clinical use of protein hydrolysates and soya formulae European J. Clin.Nutr. 45 (supl 1) :23 -8, 1991.

37 - MORAES,M.A.C., Metodos para avaliação sensorial dos alimentos. $2^{\circ} \mathrm{ed}$.. Campinas,UNICAMP, 1979.

38 - NETTO, F.M. Produção e caracterizção de hidrolisado pancreático de isolado proteico de soja para nutrição clínica . Campinas, 1992 [Tese de doutorado - Faculdade de Engenharia de Alimentos - UNICAMP]. 
39 - OLIVEIRA, M.N. ; BARUFFALDI, R.; PINTO E SILVA, M.E.M.; NIETO, R.;ALVARES,E. ; NOGUEIRA, A.C.S. Development of diets based on digested meat . In: Congresso Internacional de Quimica 10. Burgos, 1992: Actas. Associación Nacional de Químicos de España, Burgos 1992. p. 21-3.

40 - PARK, Y.K. ; DRAETTA, I.S. Aplicação de enzimas proteolíticas no amaciamento de carne de boi Rev. Bras de Tecnologia.2 : 125-29, 1971.

41 - PEDERSEN, B. Removing bitterness from protein hydrolysates Food Technol,48 (10):96-8, 1994.

42 - PHILLIPS, R.D. ; BEUCHAT, L.R. Enzime modification of proteins In: Cherry, J.P. Protein functionality in foods, Washington American Chemistry Society Div. of Agric. and Food Chemistry ., 1981. p.27498 (.A.C.S. symposium series 147 ).

43 - PINTO E SILVA, M.E.M. Teores de vitamina $C$ em alimentos de consumo habitual na região de São Paulo, São Paulo,1990. [ Dissertação de Mestrado - Faculdade de Ciências Farmacêuticas USP ].

44 - POTUS, J. ; ADRIAN, J. Conséquences de l'environnement physicochimique sur la conformation et la digestibilité des protéines Cah. Nutr. Diét., 28 117-24, 1993.

45 - PROTÉINES: porqué, como, cuanto. Vevey, Centre de Documentation, Department Affaire Publiques/Nestec, 1976/1987.

46 - ROSADO, J.L.; MORALES, M.; PASQUETTI, A.; NOBARA, R.; HERNANDEZ, L. Nutritional evaluation of a lactose hydrolyzed milk bassed enteral formula diet Rev. Invest. Clin. ,40: 141-7, 1988.

47 - SCHIMIDL, M.K.; TAYLOR,S.L.; NORDLEE, J.A. Use of hydrolysate-based products in special medical diets Food Technol 48 (10); 77-85, 1994. 
48 - SCHWIMMER, S. Source book of food enzimology. Westport, Avi Publishing Co, 1981. p. 613-32: Protein. functionality and nutritiousness as modified by enziyme action .

49 - SEKIYA,S. ; KOBAYASHI,Y.; KITYA,E.; IMAMURA,Y.; TOYAMA,S. Antihypertensive effects of tryptic hydrolysate of casein on normotensive and hypertensive volunteers Japan. Soc. Nutr. Food Sci, 45 : 513-17, 1992.

50 - SGARBIERI,V.C. Composição do abacaxi. Alimentos e bebidas, 3(1/2): 10 7, 1967

51 - SILK, D.B.A.; CHUNG,K.L.; BERGER,K.L.; CONLEY,K.; BETGLER,M.; SLEISENGER,M.H.; SPILLER,G.A. e KIM,Y.S. Comparison of oral feeding of peptide and aminoacid meals to normal human subjects. Gut,20: 291 - 9,1979."

52 - SILK, D.B.A. ; GRIMBLE,G.K. ; REES, R.G. Protein digestion and amino acid peptide absorption Proc. Nutr Soc., 44: 63-72, 1985.

53 - STABILE, M.N.O. Hidrolisados de carne bovina : biotecnologia de obtenção São Paulo, 1989 [ Dissertação de Mestrado - Faculdade de Ciências Farmacêuticas - USP ].

54 - STABILE, M.N.O. Otimização do processo biotecnológico de hidrólise de carne bovina. São Paulo, 1991 [ Tese de doutoramento - Faculdade de Ciências Farmacêuticas- USP].

55 - STABILE, M.N.O.; BARUFFALDI, R.; STEDEFELD, E. BASILIO, M.C.; PINTO E SILVA, M.E.M.; NIETO, R.A. ;ALVARES,E.D. Carne prédigerida a partir de suco de abacaxi Aliment. Tecnol.(32); 99104,1990 .

56 - STEPHAN,V.; KUHR,J.; SAWATZKI,G. ; URBANEK,R. A study of ten immunogenicity and allergenicity of an experimental cow's milk protein hydrolysate Zeitschrift fur Ernahrungswissenschaft, 29 (2): 112 21,1990 . 
57 - STONE, H. ; SIDEL, J.L. Sensory evaluation practices Orlando, Academic Press Inc. 1985. p.227-52.: Affective testing

58- TAKEDA, M. ; OKEDA, T. Utilização da carne liofilizada em dietoterapia Rev. Méd. IAMSPE, $1: 23-4,1970$.

59 - TOMÉ, D. Protéines alimentaires et métabolisme des protéines 1 - Bases physiologiques Cah. Nutr. Diét., 29 : 54-60, 1994.

60 - TRIGO, M.; SASAKI, M. Estudo da complementação alimentar protéica em prematuros (récem -nascidos de baixo peso) : avaliação de 56 casos com controle domiciliar Rev. IAMSPE, 6 $(2):$ 9-14, 1975.

61 - TORRES, E.; PEARSON, A.M.; GRAY, J.I.; BOOREN, A.M. e SHIMOKOMAKI, $M$. Effect of salt on oxidative changes in pre and post rigor ground beef Meat Science, 23: 151 - 63, 1988.

62 - VANDENPLASS, Y.; HAUSER, B.; BLEKER, U.; SUYS, B.; PEETERS, S.; KEYMOLEN, K.; LOEB, $\mathrm{H}$. The nutritional value of a whey hydrolisate formula compared with a whey-predominant formula in healthy infants. J. Pediatr. Gastroenterol. Nutr. 17 : $92-6,1993$.

63 - WEST, S. The enzyme maze Food Technol ,42(4): 98-102, 1988.

64 - ZIEGLER,F.; OLLIVIER,J.M.; CYNOBER,L.;MASINI,J.P.; COUDRAYLUCAS,C.; LEVY,E. e GIBOUDEAU,J. Effeciency of enteral nitrogen support in surgical patients: Small peptides $v$ non-degraded proteins. Gut, 31: 1277 - 83, 1990. 
VIII - ANEXOS 
FICHA DE AVALIAÇÃO

Nome:

Data:

Idade: menos de 20 anos

de 20 a 40 anos

mais de 40 anos

Avalie, por favor, esta amostra de $e$ indique com $x$ usando a escala abaixo, o quanto você gostou ou desgostou da amostra.

_ gostei extremamente

_ gostei muito

_ gostei moderadamente

_ gostei ligeiramente

_ nem gostei nem desgostei

_ desgostei ligeiramente

_ desgostei moderadamente

_ desgostei muito

_ desgostei extremamente.

Indique, por favor, o que você mais gostou e o que você menos gostou nesta amostra.

Mais gostei

Menos gostei 
TABELA 13 - Composição centesimal da carne bovina in natura ( I ) e seu hidrolisado $(\mathrm{H})^{*}$

\begin{tabular}{|c|c|c|c|c|c|c|c|c|c|}
\hline בONSTITUINTE & \multicolumn{2}{|c|}{ UMIDADE } & \multicolumn{2}{|c|}{ CINZAS } & \multicolumn{2}{|c|}{ PROTEINAS } & \multicolumn{2}{|c|}{ GORDURAS } & $\overline{\text { CARBOIDRATOS }}$ \\
\hline AMOSTRAS & I & $\mathrm{H}$ & I & $\mathrm{H}$ & I & $\mathrm{H}$ & I & $\mathrm{H}$ & $\mathrm{H}$ \\
\hline 1 & 75.59 & 81.11 & 1.77 & 0.77 & 22.10 & 11.48 & 0.91 & 0.98 & 5.66 \\
\hline 2 & 73.31 & 80.15 & 1.14 & 0.78 & 23.55 & 13.92 & 2.17 & 1.50 & 3.65 \\
\hline 3 & 74.61 & $\overline{81.01}$ & 1.22 & 0.83 & $\overline{23.16}$ & 10.89 & 0.73 & 1.40 & 5.87 \\
\hline 4 & 74.60 & $\overline{81.41}$ & 1.31 & 0.78 & 20.88 & 11.04 & 1.81 & 1.95 & 4.82 \\
\hline 5 & $\overline{73.84}$ & 80.43 & 1.16 & 0.85 & 21.18 & 11.73 & 1.84 & 1.21 & 5.78 \\
\hline 6 & 73.60 & 79.86 & 1.36 & 0.86 & 14.57 & 12.87 & 2.07 & 1.57 & 4.84 \\
\hline MEDIA & 74.26 & 80.66 & 1.33 & 0.81 & 22.47 & 11.99 & 1.59 & 1.44 & 5.10 \\
\hline $\begin{array}{l}\text { DESVIO } \\
\text { PADRÃO }\end{array}$ & 0.84 & 0.61 & 0.23 & 0.04 & 1.59 & 1.18 & 0.61 & 0.33 & 0.85 \\
\hline
\end{tabular}

[*] Para a carne in natura a unidade é $\mathrm{g} / 100 \mathrm{~g}$ e para o hidrolisado $\mathrm{g} / 100 \mathrm{ml}$. 
TABELA 14 - Composição centesimal da carne de peru in natura( I ) seu hidrolisado $(\mathrm{H})^{*}$

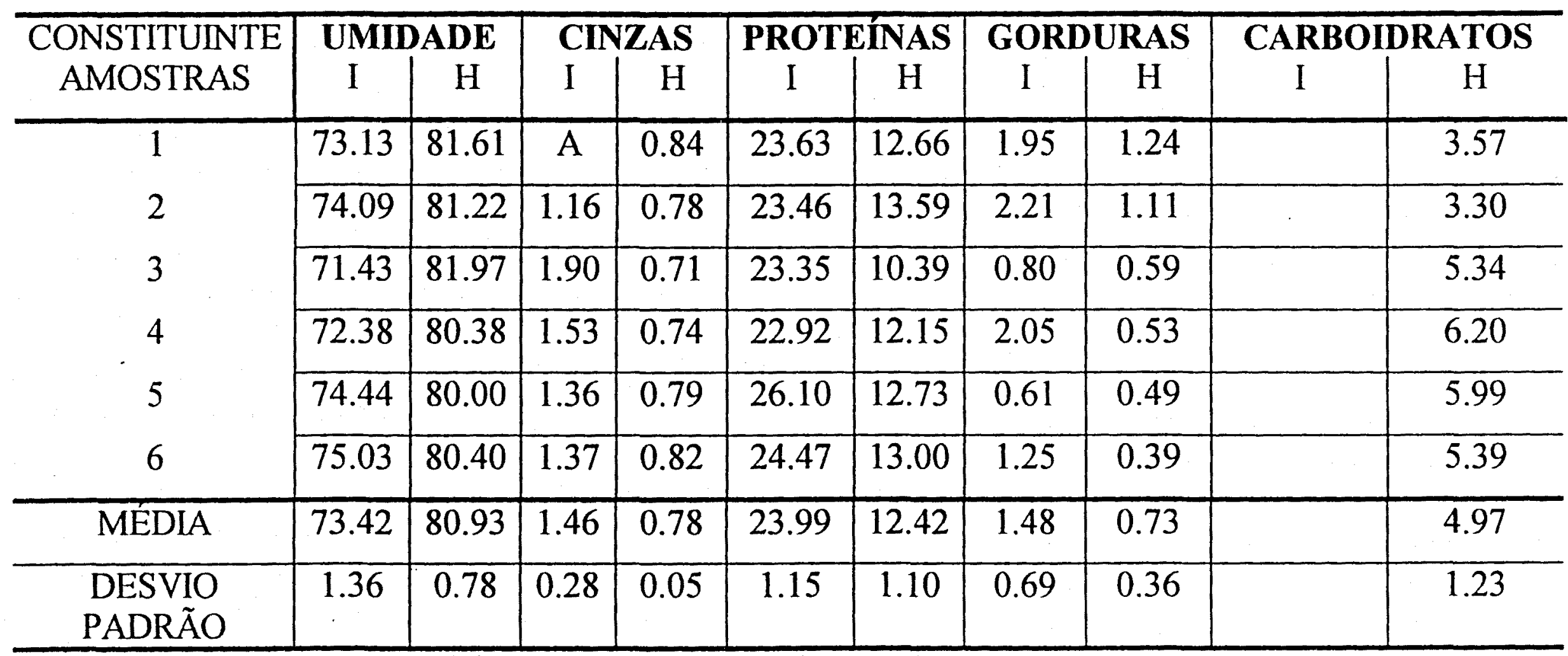

[*] Para a carne in natura a unidade é g/100g e para o hidrolisado $\mathrm{g} / 100 \mathrm{ml}$.

[A] Perda do material na análise 
TABELA 15 - Composição centesimal da carne de frango in natura (I) e seu hidrolisado $(\mathrm{H})$ *

\begin{tabular}{|c|c|c|c|c|c|c|c|c|c|}
\hline \multirow{2}{*}{$\begin{array}{l}\text { CONSTITUINTE } \\
\text { AMOSTRAS }\end{array}$} & \multicolumn{2}{|c|}{ UMIDADE } & \multicolumn{2}{|c|}{ CINZAS } & \multicolumn{2}{|c|}{ PROTEÍNAS } & \multicolumn{2}{|c|}{ GORDURAS } & CARBOIDRATOS \\
\hline & I & $\mathrm{H}$ & I & $\mathrm{H}$ & I & $\mathrm{H}$ & I & $\mathrm{H}$ & $\mathrm{H}$ \\
\hline$\overline{1}$ & 74.38 & $\longdiv { 8 0 . 5 1 }$ & 2.81 & 0.75 & 23.66 & $\overline{12.42}$ & 1.29 & 0.76 & 5.56 \\
\hline 2 & 76.23 & 82.00 & 1.27 & 0.79 & 22.74 & 13.28 & 1.09 & 1.07 & 2.86 \\
\hline 3 & 72.48 & 81.83 & 1.77 & 0.87 & 24.31 & 12.39 & 0.81 & 0.94 & 3.97 \\
\hline 4 & 73.16 & 81.20 & 1.46 & 0.78 & 23.74 & 12.78 & $\bar{A}$ & 0.63 & 4.61 \\
\hline 5 & 75.34 & 80.58 & 1.44 & 0.81 & 25.03 & 12.27 & 0.56 & 0.78 & 5.56 \\
\hline 6 & 74.79 & 80.77 & 1.52 & 0.95 & 23.81 & 12.55 & 1.39 & 0.82 & 4.91 \\
\hline MÉDIA & 74.40 & 81.15 & 1.71 & 0.83 & 23.88 & 12.62 & 1.03 & 0.83 & 4.58 \\
\hline $\begin{array}{l}\text { DESVIO } \\
\text { PADRÃO }\end{array}$ & 1.39 & 0.64 & 0.56 & 0.07 & 0.76 & 0.37 & 0.34 & 0.15 & 1.04 \\
\hline
\end{tabular}

[* ] Para carne de frango in natura a unidade é $\mathrm{g} / 100 \mathrm{~g}$ e para o hidrolisado $\mathrm{g} / 100 \mathrm{ml}$.

[A] Perda do material na análise. 


\begin{tabular}{|c|c|c|c|c|c|c|c|c|c|c|}
\hline TIPO & \multicolumn{5}{|c|}{ CARNE BOVINA } & & \multicolumn{4}{|c|}{ HIDROLISADO BOVINO } \\
\hline & & & & & & & & & & \\
\hline \multicolumn{10}{|l|}{ C8:0 } & \\
\hline C12:0 & & & 0,14 & & & & & & & \\
\hline C14:0 & 2,21 & 1,7 & 2,69 & 2,08 & 2,44 & & 2,34 & 2.71 & 1,93 & 2,27 \\
\hline * & 1,1 & 0,78 & 1,28 & 0.99 & 1,2 & & 1,16 & 1,22 & 0,41 & 1,17 \\
\hline C15:0 & 0,6 & 0.33 & 0.36 & 0,41 & 0.46 & & 0.47 & 0.44 & 0.45 & 0.47 \\
\hline * & 0,33 & 0,54 & 0,44 & 0,72 & 0,17 & & 0,31 & 0,27 & 0,48 & 0.56 \\
\hline C16:0 & 22,81 & 23,18 & 23,09 & 20,91 & 25,13 & & 24.83 & 23.9 & 21,09 & 24.52 \\
\hline C16:1 & 2,01 & 2,23 & 2,99 & 2,56 & 3,51 & & 2,59 & 2,78 & 2,2 & 3,17 \\
\hline C16:2 & 2,04 & 1,22 & 1,81 & 1,43 & 1,27 & & 0,63 & 1,78 & 1.15 & 1.87 \\
\hline$\star$ & 1,57 & 1,17 & 1,45 & 0,81 & 1.13 & & 0,93 & 1,5 & 0,8 & 0,73 \\
\hline C17:0 & 1,42 & 0,93 & 1,08 & 1,13 & 0,95 & & 1,33 & 1.35 & 1.22 & 0.51 \\
\hline * & 1,08 & 1,33 & 1,01 & 1,31 & 1,49 & & 0,85 & 1,02 & 1,4 & 2,39 \\
\hline C18:0 & 18,72 & 19,65 & 17,72 & 17,77 & 18,05 & & 17,31 & 18.05 & 17,45 & 14,76 \\
\hline C18:1 & 39,88 & 40,34 & 38,68 & 43,41 & 37,27 & & 40,66 & 38,26 & 44,5 & 40,75 \\
\hline C18:2 & 4,86 & 4,15 & 4.63 & 3,76 & 4,48 & & 4.62 & 4.18 & 4,25 & 4,68 \\
\hline C19:0 & 0,29 & 0,35 & 0,43 & 0,36 & 0,43 & & & 0.34 & 0,77 & 0.23 \\
\hline C18:3 & 0.58 & 0.63 & 0.7 & 0.92 & 0.77 & & 0.71 & 0.63 & 0.64 & 0.8 \\
\hline 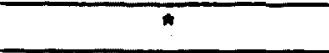 & 0,49 & 0,39 & 0,47 & 0.54 & 0.56 & & & 0.27 & & 0,59 \\
\hline C20:0 & & 0,28 & & 0,22 & 0,22 & & & 0.39 & & \\
\hline 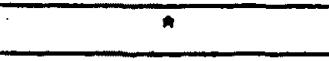 & & 0,15 & 0.28 & & & & 0,63 & & & \\
\hline C21:0 & & 0,49 & 0.37 & 0.67 & 0,29 & & 0,63 & 0.45 & 1,26 & 0.54 \\
\hline 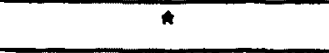 & & 0,16 & 0,13 & & 0,18 & & & 0.46 & & \\
\hline \multicolumn{11}{|l|}{ C22:0 } \\
\hline 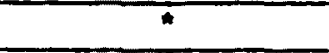 & & & & & & & & & & \\
\hline SATURADOS & 45,77 & 46,91 & 45.52 & 43,19 & 47.54 & & 46,91 & 47.42 & 44,17 & 43,07 \\
\hline MONOINSATURADOS & 41,89 & 42,57 & 41,67 & 45,96 & 40,78 & & 43,25 & 41,04 & 46,7 & 43,92 \\
\hline POLINSATURADOS & 7,48 & 6 & 7,15 & 6,12 & 6,52 & & 5,96 & 6.59 & 6.04 & 7,35 \\
\hline - NĀO IDENTIFICADO & 4,86 & 4,52 & 5,66 & 4,73 & 5,16 & & 3,88 & 4,96 & 3,09 & 5,87 \\
\hline
\end{tabular}




\begin{tabular}{|c|c|c|c|c|c|c|c|c|c|c|c|}
\hline \multirow[t]{2}{*}{ TIPO } & \multicolumn{5}{|c|}{ CARNE PERU } & & \multicolumn{5}{|c|}{ HIDROLISADO PERU } \\
\hline & & & & & & & 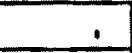 & & & & . \\
\hline C8:0 & & & & & & & 0,09 & & 0,14 & & 0,08 \\
\hline C12:0 & & & & & & & & & & & 0.09 \\
\hline C14:0 & 0,73 & 1,25 & 0,92 & 0,64 & 0,76 & & 0,77 & 0.71 & 0,7 & 0,62 & 0,75 \\
\hline 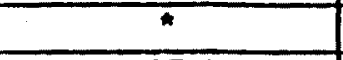 & 0,25 & 0,58 & 036 & 0.66 & & & & & & & \\
\hline C15:0 & 0,13 & 0,3 & 0,39 & & 0.17 & & 0,16 & & & & 0,2 \\
\hline * & & 1,56 & & & & & & & 1,06 & 0.52 & 1,24 \\
\hline C16:0 & 23,26 & 29,01 & 25,59 & 20.81 & 23,74 & & 21,83 & 24.28 & 21,18 & 21,2 & 18,95 \\
\hline C16:1 & 7,32 & 3,15 & 4,64 & 3,16 & 3,21 & & 3,9 & 1,79 & 2,39 & 2,04 & 1,59 \\
\hline C16:2 & 0,12 & 1,26 & 0.08 & 1,48 & 0.99 & & 1.63 & 0,85 & 0.44 & 1,12 & 1,47 \\
\hline 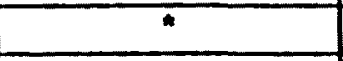 & & & & & & & 0.43 & & & & \\
\hline C17:0 & 0,22 & 0.43 & 0,35 & 0.28 & 0,3 & & 0.29 & & & 0,31 & 0.44 \\
\hline 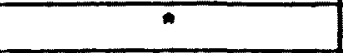 & 0,18 & & 0.19 & & & & & & & & 0.32 \\
\hline C18:0 & 7,91 & 11,68 & 9,44 & 8,42 & 8,58 & & 7,42 & 13,86 & 10,09 & 11,67 & 10.93 \\
\hline C18:1 & 31,3 & 32 & 30.74 & 26,32 & 27,24 & & 28,92 & 27,18 & 23.86 & 21,11 & 21,25 \\
\hline C18:2 & 24,49 & 16,43 & 23,54 & 30,9 & 29,72 & & 29,06 & 23,24 & 26.47 & 23,99 & 29,79 \\
\hline C19:0 & & 0,64 & 0.1 & 2,08 & 1,35 & & 1,99 & 0.77 & 2,46 & 1,12 & 2.11 \\
\hline C18:3 & 1.85 & 0,43 & 1,11 & 1.79 & 2.1 & & 2.04 & 1.56 & 0.59 & 1.48 & 1,89 \\
\hline$*$ & 0,18 & & 0,19 & 0,74 & & & 0,27 & & 0,65 & & 0.36 \\
\hline C20:0 & 0,21 & 0,93 & 0.51 & & 0.22 & & & & & & 0,26 \\
\hline 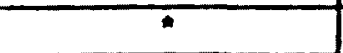 & 0,24 & & 0,98 & & 0.26 & & & & & 1,05 & 0,84 \\
\hline C21:0 & 0,77 & & & 2,2 & 1,37 & & 1,2 & 4.68 & 4,22 & 5,6 & 4,64 \\
\hline$n$ & 0,6 & & & & & & & & 0.9 & & 0,29 \\
\hline C22:0 & & & 0,87 & & & & & & & 8,17 & \\
\hline 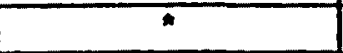 & 0,24 & & & 0.52 & & & & 1.08 & 4.85 & & 1,85 \\
\hline C24:0 & & & & & & & & & & & 0.64 \\
\hline SATURADOS & 33,23 & 43,31 & 38,17 & 34,43 & 36,49 & & 33,75 & 38.95 & 39,23 & 40,52 & 40,1 \\
\hline MONOINSATURADOS & 38,62 & 35,5 & 35,38 & 29,48 & 30,45 & & 32,82 & 28,97 & 28.25 & 23,15 & 22.84 \\
\hline POLINSATURADOS & 26,34 & 18,12 & 24,73 & 34,17 & 32,8 & & 32,73 & 26,42 & 27,06 & 26,59 & 33,15 \\
\hline - NAO IDENTIFICADO & 1,81 & 3,07 & 1,72 & 1,92 & 0,26 & & 0.7 & 5,72 & 4,85 & 9,74 & 3,91 \\
\hline
\end{tabular}




\begin{tabular}{|c|c|c|c|c|c|c|c|c|c|c|c|}
\hline TIPO & \multicolumn{5}{|c|}{ CARNE FRANGO } & & \multicolumn{5}{|c|}{ HIDROLISADO FRANGO } \\
\hline & & & & & & & & & & & \\
\hline C8:0 & & & & & & & & & & 0,11 & \\
\hline C12:0 & & & & & & & & & & & 0.09 \\
\hline C14:0 & 0.62 & 0.52 & 0,45 & 0,53 & 0.58 & & 0.53 & 0.77 & 0.65 & 0,66 & 0,81 \\
\hline 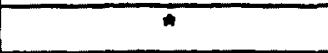 & 0.53 & 0,67 & 0,16 & 0,42 & 0,23 & & & & 0,49 & 0,19 & 0,47 \\
\hline C15:0 & & & & & 0,08 & & & & & & \\
\hline * & & & & & & & & & & & \\
\hline C16:0 & 24,11 & 23,63 & 22,49 & 22,12 & 22,25 & & 24,05 & 24,68 & 25,44 & 22,39 & 24,4 \\
\hline C16:1 & 6,69 & 5,63 & 6,22 & 6,72 & 7,65 & & 5,57 & 7,12 & 6,72 & 5,99 & 6,55 \\
\hline C16:2 & & 1,68 & 1,2 & 1,66 & 1,17 & & 1,99 & 1.45 & 1 & 1,21 & 1,33 \\
\hline 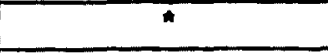 & & 0.49 & 0,5 & 0,49 & 0,4 & & 0.57 & 0.47 & 0.29 & 0,38 & 0,42 \\
\hline C17:0 & & & & 0,11 & 0,14 & & & & & & \\
\hline " & & & & 0,14 & 0,13 & & & & & & \\
\hline C18:0 & 6,95 & 7,01 & 8,02 & 5,85 & 5.9 & & 8 & 6,65 & 7,38 & 7,29 & 6.7 \\
\hline C18:1 & 43,09 & 37,46 & 31,93 & 39,08 & 35,98 & & 36,72 & 34,65 & 38,44 & 35,85 & 39,44 \\
\hline $\mathrm{C18:2}$ & 15,51 & 17,74 & 17,14 & 18,03 & 21,69 & & 18,34 & 20,77 & 15,99 & 13,81 & 16,72 \\
\hline C19:0 & & 1.16 & 0,8 & 1,28 & 1.28 & & 1,16 & 1.09 & 0.55 & 0,62 & 0.93 \\
\hline C18:3 & 0.83 & 0,56 & 0,9 & 0.75 & 1,11 & & 0.59 & 1,44 & 0,52 & 0,82 & 0,66 \\
\hline 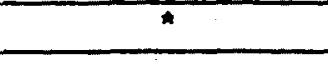 & & 0,37 & 0,17 & 0.29 & 0,24 & & & & & 0,49 & \\
\hline C20:0 & 0,44 & 0,43 & & 0,35 & 0,38 & & & & 0.38 & 0.45 & 0.42 \\
\hline 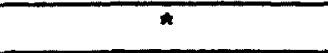 & 0,32 & 0.69 & 1,43 & 0.56 & 0,38 & & & & 0,43 & 0,48 & \\
\hline C21:0 & 0,96 & 1,58 & 2,6 & 1,32 & 0.41 & & 2.48 & 0.91 & 1,72 & 1,77 & 1,03 \\
\hline 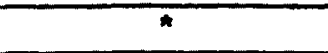 & & 0,37 & 1,2 & 0,3 & & & & & & & \\
\hline C22:0 & & & & & & & & & & & \\
\hline$\star$ & & & 4,79 & & & & & & & 5,74 & \\
\hline SATURADOS & 33,08 & 34,34 & 34,36 & 31,56 & 31,02 & & 36,22 & 34,1 & 36,12 & 33,52 & 34,39 \\
\hline MONOINSATURADOS & 49,73 & 43,09 & 38,15 & 45,8 & 43,63 & & 42,29 & 41,77 & 45,16 & 41.84 & 45,99 \\
\hline POLINSATURADOS & 16,34 & 19,98 & 19,24 & 20,44 & 23,97 & & 20,82 & 23,66 & 17,51 & 15,91 & 18,73 \\
\hline - NAOO IDENTIFICADO & 0,85 & 2,59 & 8,25 & 2,2 & 1,38 & & 0,57 & 0,47 & 1,21 & 8,73 & 0,89 \\
\hline
\end{tabular}


SOPA DE LEGUMES - padrão

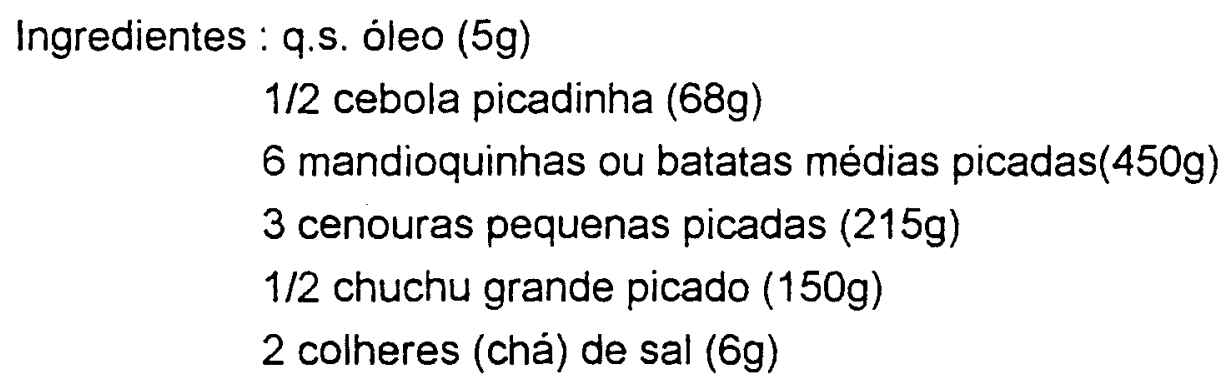

Preparo: Aquecer o óleo, acrescentar a cebola e dourar. Juntar $1000 \mathrm{ml}$ de água, a mandioquinha ou a batata, a cenoura, o chuchu e o sal. Deixar cozinhando até que os legumes estejam macios. 
ANEXO 4

SOPA DE BETERRABA - adaptada

Ingredientes : q.s. óleo $(5 \mathrm{~g})$

$1 / 2$ cebola picadinha $(68 \mathrm{~g})$

3 beterrabas médias $(600 \mathrm{~g})$

3 cenouras pequenas $(215 \mathrm{~g}$ )

2 colheres (chá) de sal $(6 \mathrm{~g})$

$11 / 2$ xicara (chá) de carne hidrolisada (300ml)

Preparo: Aquecer o óleo, acrescentar a cebola e dourar. Juntar $500 \mathrm{ml}$ de água, a beterraba, a cenoura e o sal. Deixar cozinhando até que os legumes estejam macios. Depois de cozidos, bater no liquidificador, até obter a consistência de creme. Acrescentar a carne hidrolisada e misturar. Tornar a aquecer se necessário, sem ferver.

Rendimento:4 porções (1 litro) 


\begin{tabular}{|c|c|c|c|c|c|c|}
\hline \multirow[b]{2}{*}{ NUTRIENTES } & \multicolumn{2}{|l|}{ CARNE } & \multicolumn{2}{|c|}{ CARNE DE PERU } & \multicolumn{2}{|c|}{ CARNE DE FRANGO } \\
\hline & $\begin{array}{c}\text { SEḾ } \\
\text { HIDROLISADO }\end{array}$ & $\begin{array}{c}\text { COM } \\
\text { HIDKOULISADO }\end{array}$ & $\begin{array}{c}\text { SEM } \\
\text { HIDROLISADO }\end{array}$ & $\begin{array}{c}\text { COM } \\
\text { HIDROLISADO }\end{array}$ & $\begin{array}{c}\text { SEM } \\
\text { HIDROLISADO }\end{array}$ & $\begin{array}{c}\text { COM } \\
\text { HIDROLISADO }\end{array}$ \\
\hline ENERGIA & $650 \mathrm{cal}$ & $728 \mathrm{cal}$ & $656 \mathrm{cal}$ & $734 \mathrm{cal}$ & $599 \mathrm{cal}$ & $677 \mathrm{cal}$ \\
\hline PROTEINA TOTAL & $45.8 \mathrm{~g}$ & $46.4 \mathrm{~g}$ & $49.5 \mathrm{~g}$ & $50.1 \mathrm{~g}$ & $46.5 \mathrm{~g}$ & $47.1 \mathrm{~g}$ \\
\hline PROTEINA ANIMAL & $32.3 \mathrm{~g}$ & $32.3 \mathrm{~g}$ & $36.0 \mathrm{~g}$ & $36.0 \mathrm{~g}$ & $33.0 \mathrm{~g}$ & $33.0 \mathrm{~g}$ \\
\hline LIPIDIOS TOTAIS & $18.3 \mathrm{~g}$ & $18.6 \mathrm{~g}$ & $16.1 \mathrm{~g}$ & $16.4 \mathrm{~g}$ & $11.1 \mathrm{~g}$ & $11.4 \mathrm{~g}$ \\
\hline LIPIDIOS SATURADOS & $6.9 \mathrm{~g}$ & $6.9 \mathrm{~g}$ & $3.8 \mathrm{~g}$ & $3.8 \mathrm{~g}$ & $2.3 \mathrm{~g}$ & $2.3 \mathrm{~g}$ \\
\hline LIPIDIOS INSATURADOS & $7.0 \mathrm{~g}$ & $7.0 \mathrm{~g}$ & $5.5 \mathrm{~g}$ & $5.5 \mathrm{~g}$ & $2.5 \mathrm{~g}$ & $2.5 \mathrm{~g}$ \\
\hline AC.GRAXOS ESSENCIAIS & $2.6 \mathrm{~g}$ & $2.6 \mathrm{~g}$ & $4.1 \mathrm{~g}$ & $4.1 \mathrm{~g}$ & $4.1 \mathrm{~g}$ & $4.1 \mathrm{~g}$ \\
\hline COLESTEROL & $98 \mathrm{mg}$ & $98 \mathrm{mg}$ & $123 \mathrm{mg}$ & $123 \mathrm{mg}$ & $147 \mathrm{mg}$ & $147 \mathrm{mg}$ \\
\hline VITAMINA A & $2378 \mu \mathrm{g}$ & $2386 \mu \mathrm{g}$ & $2378 \mu \mathrm{g}$ & $2386 \mu g$ & $2416 \mu g$ & $2423 \mu \mathrm{g}$ \\
\hline VITAMINA B 1 & $0.32 \mathrm{mg}$ & $0.44 \mathrm{mg}$ & $0.34 \mathrm{mg}$ & $0.46 \mathrm{mg}$ & $0.32 \mathrm{mg}$ & $0.44 \mathrm{mg}$ \\
\hline VITAMINA B 2 & $0.65 \mathrm{mg}$ & $0.71 \mathrm{mg}$ & $0.58 \mathrm{mg}$ & $0.64 \mathrm{mg}$ & $0.59 \mathrm{mg}$ & $0.65 \mathrm{mg}$ \\
\hline NIACINA & $7.0 \mathrm{mg}$ & $7.3 \mathrm{mg}$ & $14.7 \mathrm{mg}$ & $15.0 \mathrm{mg}$ & $14.7 \mathrm{mg}$ & $15.0 \mathrm{mg}$ \\
\hline VITAMINAC & $54 \mathrm{mg}$ & $146 \mathrm{mg}$ & $54 \mathrm{mg}$ & $146 \mathrm{mg}$ & $54 \mathrm{mg}$ & $84.5 \mathrm{~g}$ \\
\hline CARBOIDRATOS & $84.5 \mathrm{~g}$ & $105.0 \mathrm{~g}$ & $84.5 \mathrm{~g}$ & $105.0 \mathrm{~g}$ & $84.5 \mathrm{~g}$ & $14.6 \mathrm{~g}$ \\
\hline CÁLCIO & $208 \mathrm{mg}$ & $235 \mathrm{mg}$ & $196 \mathrm{mg}$ & $223 \mathrm{mg}$ & $202 \mathrm{mg}$ & $229 \mathrm{mg}$ \\
\hline FERRO TOTAL & $13.0 \mathrm{mg}$ & $13.7 \mathrm{mg}$ & $9.2 \mathrm{mg}$ & $10.0 \mathrm{mg}$ & $8.9 \mathrm{mg}$ & $9.7 \mathrm{mg}$ \\
\hline FERRO ANIMAL & $6.0 \mathrm{mg}$ & $6.0 \mathrm{mg}$ & $2.3 \mathrm{mg}$ & $2.3 \mathrm{mg}$ & $2.0 \mathrm{mg}$ & $2.0 \mathrm{mg}$ \\
\hline FÓSFORO & $601 \mathrm{mg}$ & $613 \mathrm{mg}$ & $651 \mathrm{mg}$ & $663 \mathrm{mg}$ & $637 \mathrm{mg}$ & $649 \mathrm{mg}$ \\
\hline MAGNESIO & $244 \mathrm{mg}$ & $263 \mathrm{mg}$ & $268 \mathrm{mg}$ & $287 \mathrm{mg}$ & $242 \mathrm{mg}$ & $262 \mathrm{mg}$ \\
\hline POTÁSSIO & $3382 \mathrm{mg}$ & $3601 \mathrm{mg}$ & $3285 \mathrm{mg}$ & $3504 \mathrm{mg}$ & $3685 \mathrm{mg}$ & $3504 \mathrm{mg}$ \\
\hline SODDIO & $565 \mathrm{mg}$ & $567 \mathrm{mg}$ & $576 \mathrm{mg}$ & $577 \mathrm{mg}$ & $576 \mathrm{mg}$ & $577 \mathrm{mg}$ \\
\hline
\end{tabular}


ANEXO 5

BOLINHO DE BATATA - padrão

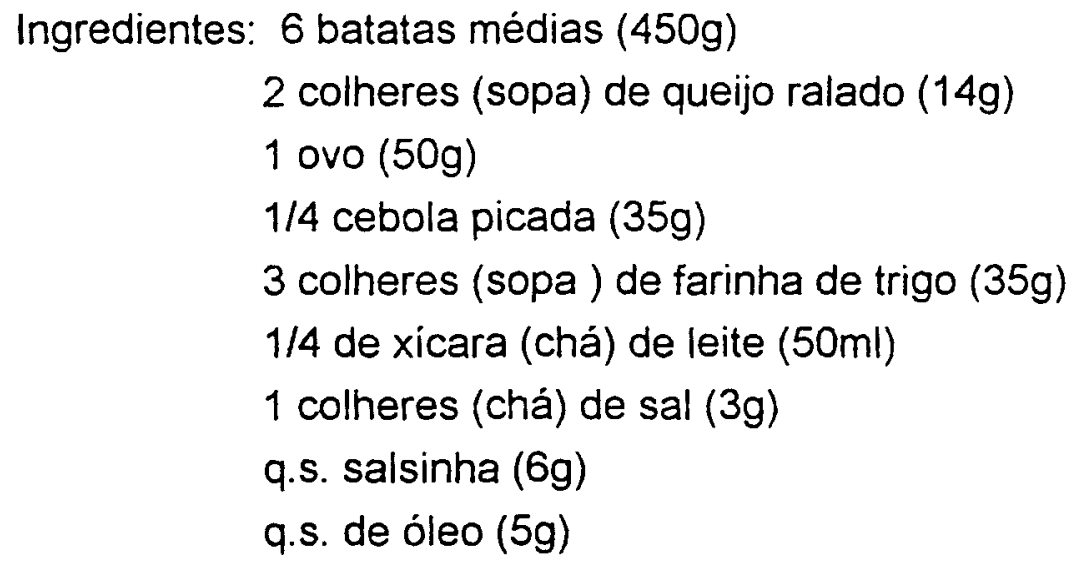

Preparo: Descascar as batatas, cortar e cozinhar. Espremê-las, juntar o queijo ralado, o ovo, a cebola, a farinha de trigo, o leite, o sal e a salsinha. Misturar tudo muito bem. Fritar em óleo bem quente. 


\section{BOLINHO DE BATATA - adaptada}

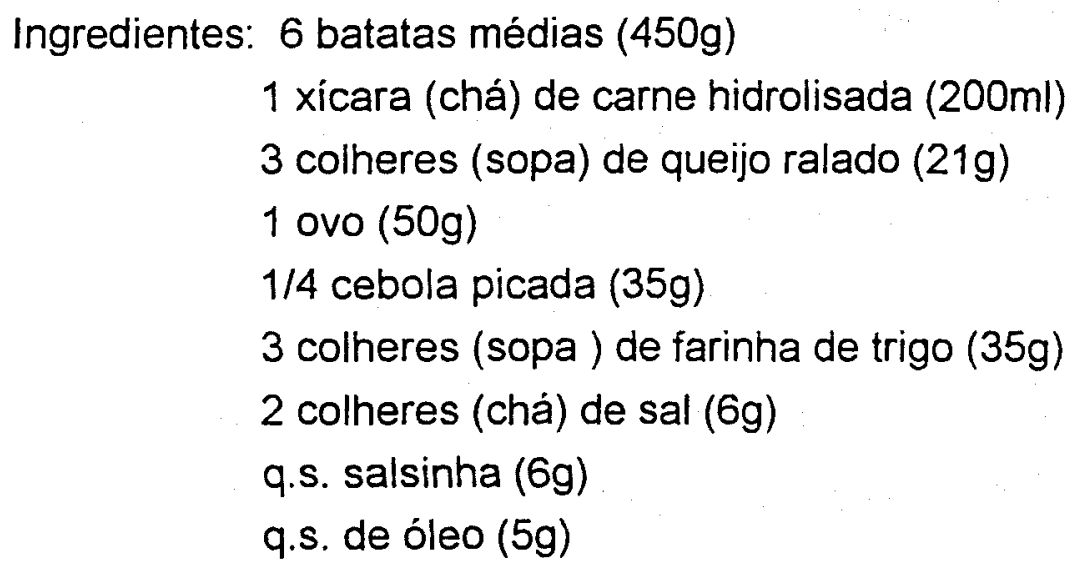

Preparo: Descascar as batatas, cortar e cozinhar com a carne hidrolisada em 1 xicara de água (se necessário acrescentar mais). Espremê-las, juntar o queijo ralado, o ovo, a cebola, a farinha de trigo, o sal e a salsinha. Misturar tudo muito bem. Fritar em óleo bem quente.

Rendimento: 30 unidades médias $(800 \mathrm{~g})$ 


\begin{tabular}{|l|c|c|c|c|}
\hline NUTRIENTES & $\begin{array}{c}\text { SEM } \\
\text { HIDROLISADO }\end{array}$ & $\begin{array}{c}\text { COM } \\
\text { HIDROLISADO } \\
\text { BOVINO }\end{array}$ & $\begin{array}{c}\text { COM } \\
\text { HIDROLISADO } \\
\text { DE PERU }\end{array}$ & $\begin{array}{c}\text { COM } \\
\text { HIDROLISADO } \\
\text { DE FRANGO }\end{array}$ \\
\hline ENERGIA & $690 \mathrm{cal}$ & $942 \mathrm{cal}$ & $996 \mathrm{cal}$ & $901 \mathrm{cal}$ \\
\hline PROTEINA TOTAL & $27.0 \mathrm{~g}$ & $53.3 \mathrm{~g}$ & $59.9 \mathrm{~g}$ & $53.9 \mathrm{~g}$ \\
\hline PROTEINA ANIMAL & $14.0 \mathrm{~g}$ & $39.8 \mathrm{~g}$ & $42.8 \mathrm{~g}$ & $40.4 \mathrm{~g}$ \\
\hline LIPIDIOS TOTAIS & $17.2 \mathrm{~g}$ & $27.2 \mathrm{~g}$ & $26.1 \mathrm{~g}$ & $21.4 \mathrm{~g}$ \\
\hline LIPIDIOS SATURADOS & $5.7 \mathrm{~g}$ & $10.6 \mathrm{~g}$ & $8.1 \mathrm{~g}$ & $6.9 \mathrm{~g}$ \\
\hline LIPIDIOSINSATURADOS & $5.0 \mathrm{~g}$ & $9.8 \mathrm{~g}$ & $8.6 \mathrm{~g}$ & $6.2 \mathrm{~g}$ \\
\hline AC.GRAXOS ESSENCIAIS & $3.7 \mathrm{~g}$ & $3.7 \mathrm{~g}$ & $4.9 \mathrm{~g}$ & $4.9 \mathrm{~g}$ \\
\hline COLESTEROL & $272 \mathrm{mg}$ & $350 \mathrm{mg}$ & $370 \mathrm{mg}$ & $390 \mathrm{mg}$ \\
\hline VITAMINAA & $355 \mathrm{gg}$ & $361 \mathrm{\mu g}$ & $1053 \mathrm{\mu g}$ & $391 \mathrm{\mu g}$ \\
\hline VITAMINAB 1 & $0.57 \mathrm{mg}$ & $0.75 \mathrm{mg}$ & $0.90 \mathrm{mg}$ & $0.75 \mathrm{mg}$ \\
\hline VITAMINA B & $0.49 \mathrm{mg}$ & $0.76 \mathrm{mg}$ & $0.98 \mathrm{mg}$ & $0.72 \mathrm{mg}$ \\
\hline NIACINA & $7.7 \mathrm{mg}$ & $11.4 \mathrm{mg}$ & $18.7 \mathrm{mg}$ & $17.5 \mathrm{mg}$ \\
\hline VITAMINAC & $84 \mathrm{mg}$ & $157 \mathrm{mg}$ & $324 \mathrm{mg}$ & $157 \mathrm{mg}$ \\
\hline CARBOIDRATOS & $111.4 \mathrm{~g}$ & $127.8 \mathrm{~g}$ & $137.5 \mathrm{~g}$ & $127.8 \mathrm{~g}$ \\
\hline CALCIO & $327 \mathrm{mg}$ & $368 \mathrm{mg}$ & $581 \mathrm{mg}$ & $363 \mathrm{mg}$ \\
\hline FERRO TOTAL & $6.3 \mathrm{mg}$ & $11.7 \mathrm{mg}$ & $12.2 \mathrm{mg}$ & $8.4 \mathrm{mg}$ \\
\hline FERRO ANIMAL & $1.7 \mathrm{mg}$ & $6.5 \mathrm{mg}$ & $3.5 \mathrm{mg}$ & $3.2 \mathrm{mg}$ \\
\hline FOSFORO & $539 \mathrm{mg}$ & $763 \mathrm{mg}$ & $862 \mathrm{mg}$ & $792 \mathrm{mg}$ \\
\hline MAGNESIO & $130 \mathrm{mg}$ & $174 \mathrm{mg}$ & $240 \mathrm{mg}$ & $173 \mathrm{mg}$ \\
\hline POTASSIO & $2059 \mathrm{mg}$ & $2660 \mathrm{mg}$ & $3411 \mathrm{mg}$ & $2582 \mathrm{mg}$ \\
\hline SODIO & $236 \mathrm{mg}$ & $315 \mathrm{mg}$ & $374 \mathrm{mg}$ & $323 \mathrm{mg}$ \\
\hline
\end{tabular}




\section{ANEXO 6}

\section{VITAMINA DE LEGUMES E FRUTAS - padrão}

Ingredientes: 1 cenoura média, descascada e raspada (60g)

1 tomate médio $(30 \mathrm{~g})$

$1 / 2$ maçã média descascada $(40 \mathrm{~g})$

1 xícara (chá) de suco de laranja

$1 / 3$ lata de leite condensado $(100 \mathrm{~g})$

gelo picado a gosto

Preparo: Picar a cenoura, o tomate e a maçã. Bater primeiro a cenoura no liquidificador com 1 xicara do suco, logo após acrescentar o tomate e a maçã. Acrescentar o leite condensado, e bater mais um pouco. Juntar gelo picado e servir 


\section{ANEXO 6}

\section{VITAMINA DE LEGUMES E FRUTA - adaptada}

Ingredientes: 1 cenoura média, descascada $(60 \mathrm{~g})$

1 tomate médio $(30 \mathrm{~g})$

$1 / 2$ maçã média descascada $(40 \mathrm{~g})$

$11 / 2$ xicaras (chá) de carne hidrolisada ( $300 \mathrm{ml}$ )

$1 / 3$ lata de leite condensado $(100 \mathrm{~g}$ )

gelo picado a gosto

Preparo: Picar a cenoura, o tomate e a maçã. Bater primeiro a cenoura no liquidificador com 1 xicara de hidrolisado, logo após acrescentar o tomate e a maçă. Acrescentar o restante da carne hidrolisada e o leite condensado, e bater mais um pouco. Juntar gelo picado e servir

Rendimento: 4 copos ( 1 litro) 


\begin{tabular}{|l|c|c|c|c|}
\hline NUTRIENTES & $\begin{array}{c}\text { SEM } \\
\text { HIDROLISADO } \\
\text { COM SUCO DE } \\
\text { LARANJA }\end{array}$ & $\begin{array}{c}\text { COM } \\
\text { HIDROLISADO } \\
\text { BOVINO }\end{array}$ & $\begin{array}{c}\text { COM } \\
\text { HIDROLISADO } \\
\text { DE PERU }\end{array}$ & $\begin{array}{c}\text { COMDROLISADO } \\
\text { DE FRANGO }\end{array}$ \\
\hline ENERGIA & $418 \mathrm{cal}$ & $796 \mathrm{cal}$ & $804 \mathrm{cal}$ & $728 \mathrm{cal}$ \\
\hline PROTEINA TOTAL & $9,5 \mathrm{~g}$ & $52.9 \mathrm{~g}$ & $57.9 \mathrm{~g}$ & $53.9 \mathrm{~g}$ \\
\hline PROTEINA ANIMAL & $8.1 \mathrm{~g}$ & $51.1 \mathrm{~g}$ & $56.1 \mathrm{~g}$ & $52.1 \mathrm{~g}$ \\
\hline CARBOIDRATOS & $76.9 \mathrm{~g}$ & $95.0 \mathrm{~g}$ & $95.0 \mathrm{~g}$ & $95.0 \mathrm{~g}$ \\
\hline LIPIDIOS TOTAIS & $9.3 \mathrm{~g}$ & $25.6 \mathrm{~g}$ & $22.6 \mathrm{~g}$ & $16.0 \mathrm{~g}$ \\
\hline LIPIDIOS SATURADOS & $4.0 \mathrm{~g}$ & $12.2 \mathrm{~g}$ & $8.0 \mathrm{~g}$ & $6.0 \mathrm{~g}$ \\
\hline LIPIDIOSINSATURADOS & $3.0 \mathrm{~g}$ & $11.0 \mathrm{~g}$ & $9.0 \mathrm{~g}$ & $5.0 \mathrm{~g}$ \\
\hline AC.GRAXOS ESSENCIAIS & $0.0 \mathrm{~g}$ & $0.0 \mathrm{~g}$ & $2.0 \mathrm{~g}$ & $2.0 \mathrm{~g}$ \\
\hline COLESTEROL & $34 \mathrm{mg}$ & $164 \mathrm{mg}$ & $198 \mathrm{mg}$ & $230 \mathrm{mg}$ \\
\hline VITAMINA A & $779 \mu \mathrm{g}$ & $776 \mu \mathrm{g}$ & $776 \mu \mathrm{g}$ & $826 \mu \mathrm{g}$ \\
\hline VITAMINA B 1 & $0.20 \mathrm{mg}$ & $0.45 \mathrm{mg}$ & $0.47 \mathrm{mg}$ & $0.45 \mathrm{mg}$ \\
\hline VITAMINA B 2 & $0.47 \mathrm{mg}$ & $0.90 \mathrm{mg}$ & $0.81 \mathrm{mg}$ & $0.83 \mathrm{mg}$ \\
\hline NIACINA & $1.1 \mathrm{mg}$ & $7.1 \mathrm{mg}$ & $17.3 \mathrm{mg}$ & $17.3 \mathrm{mg}$ \\
\hline VITAMINA C & $68 \mathrm{mg}$ & $137 \mathrm{mg}$ & $137 \mathrm{mg}$ & $137 \mathrm{mg}$ \\
\hline CALCIO & $300 \mathrm{mg}$ & $357 \mathrm{mg}$ & $341 \mathrm{mg}$ & $349 \mathrm{mg}$ \\
\hline FERRO TOTAL & $1.6 \mathrm{mg}$ & $9.9 \mathrm{mg}$ & $4.9 \mathrm{mg}$ & $4.5 \mathrm{mg}$ \\
\hline FERRO ANIMAL & $0.1 \mathrm{mg}$ & $8.1 \mathrm{mg}$ & $3.1 \mathrm{mg}$ & $2.7 \mathrm{mg}$ \\
\hline FOSFORO & $254 \mathrm{mg}$ & $613 \mathrm{mg}$ & $679 \mathrm{mg}$ & $661 \mathrm{mg}$ \\
\hline MAGNESIO & $57 \mathrm{mg}$ & $120 \mathrm{mg}$ & $152 \mathrm{mg}$ & $48 \mathrm{mg}$ \\
\hline POTASSIO & $836 \mathrm{mg}$ & $1638 \mathrm{mg}$ & $1508 \mathrm{mg}$ & $1508 \mathrm{mg}$ \\
\hline SODIO & $143 \mathrm{mg}$ & $274 \mathrm{mg}$ & $288 \mathrm{mg}$ & $288 \mathrm{mg}$ \\
\hline
\end{tabular}




\section{ANEXO 7}

\section{MUSSE DE FRUTA - padrão}

Ingredientes: 2 pacotes de gelatina em pó sem sabor (24g)

$1 / 2$ xicara (chá ) de água ( $100 \mathrm{ml}$ )

12 cubos de suco congelado da fruta $(300 \mathrm{ml})$

1 xícara (chá) de suco (200ml)

4 colheres (sopa) de açúcar (40g)

Preparo: Ferver a água para dissolver a gelatina. Bater no liquidificador a gelatina dissolvida e acrescentar aos poucos os cubos de gelo, o suco de fruta e o açúcar, batendo mais um pouco. Despejar imediatamente na forma e levar para gelar. 


\section{MUSSE DE UVA - adaptada}

Ingredientes: $1 / 2$ xícara (chá) de hidrolisado (100ml)

2 pacotes de gelatina em pó sem sabor $(24 \mathrm{~g})$

12 cubos de suco de uva congelado $(300 \mathrm{ml})$

1 xicara (chá) de suco de uva $(200 \mathrm{ml}$ )

4 colheres (sopa) de açúcar (40g)

Preparo: Ferver $1 / 2$ xícara (chá) de hidrolisado para dissolver a gelatina. Bater no liquidificador a gelatina dissolvida e acrescentar aos poucos os cubos de gelo, o suco de uva e o açúcar, batendo mais um pouco. Despejar imediatamente na forma e levar para gelar.

Rendimento: 6 porções $(600 \mathrm{ml})$ 


\begin{tabular}{|l|c|c|c|c|}
\hline NUTRIENTES & $\begin{array}{c}\text { SEM } \\
\text { HIDROLISADO }\end{array}$ & $\begin{array}{c}\text { COM } \\
\text { HIDROLISADO } \\
\text { BOVINO }\end{array}$ & $\begin{array}{c}\text { COM } \\
\text { HIDROLISADO } \\
\text { DE PERU }\end{array}$ & $\begin{array}{c}\text { COM } \\
\text { HIDROLISADO } \\
\text { FRANGO }\end{array}$ \\
\hline ENERGIA & $949 \mathrm{cal}$ & $1106 \mathrm{cal}$ & $1110 \mathrm{cal}$ & $1072 \mathrm{cal}$ \\
\hline PROTEINA TOTAL & $18.2 \mathrm{~g}$ & $39.7 \mathrm{~g}$ & $42.2 \mathrm{~g}$ & $40.2 \mathrm{~g}$ \\
\hline PROTEINA ANIMAL & $15.8 \mathrm{~g}$ & $37.3 \mathrm{~g}$ & $39.8 \mathrm{~g}$ & $37.8 \mathrm{~g}$ \\
\hline CARBOIDRATOS & $230.0 \mathrm{~g}$ & $230.3 \mathrm{~g}$ & $230.3 \mathrm{mg}$ & $230.3 \mathrm{~g}$ \\
\hline LIPIDIOS TOTAIS & $15.9 \mathrm{~g}$ & $24.1 \mathrm{~g}$ & $22.6 \mathrm{~g}$ & $19.3 \mathrm{~g}$ \\
\hline LIPIDIOS SATURADOS & $0.0 \mathrm{~g}$ & $4.1 \mathrm{~g}$ & $2.0 \mathrm{~g}$ & $1.0 \mathrm{~g}$ \\
\hline LIPIDIOS INSATURADOS & $0 \mathrm{~g}$ & $4.0 \mathrm{~g}$ & $3.0 \mathrm{~g}$ & $1.0 \mathrm{~g}$ \\
\hline AC.GRAXOS ESSENCIAIS & $0.0 \mathrm{~g}$ & $1.0 \mathrm{~g}$ & $1.0 \mathrm{~g}$ & $1.0 \mathrm{~g}$ \\
\hline COLESTEROL & $0 \mathrm{mg}$ & $65 \mathrm{mg}$ & $82 \mathrm{mg}$ & $98 \mathrm{mg}$ \\
\hline VITAMINA A & $120 \mu \mathrm{g}$ & $105 \mu \mathrm{g}$ & $105 \mu \mathrm{g}$ & $130 \mu \mathrm{g}$ \\
\hline VITAMINA B 1 & $0.18 \mathrm{mg}$ & $0.30 \mathrm{mg}$ & $0.31 \mathrm{mg}$ & $0.30 \mathrm{mg}$ \\
\hline VITAMINA B 2 & $0.12 \mathrm{mg}$ & $0.33 \mathrm{mg}$ & $0.28 \mathrm{mg}$ & $0.29 \mathrm{mg}$ \\
\hline NIACINA & $1.2 \mathrm{mg}$ & $4.1 \mathrm{mg}$ & $9.2 \mathrm{mg}$ & $9.2 \mathrm{mg}$ \\
\hline VITAMINA C & $108 \mathrm{mg}$ & $151 \mathrm{mg}$ & $151 \mathrm{mg}$ & $151 \mathrm{mg}$ \\
\hline CALCIO & $82 \mathrm{mg}$ & $106 \mathrm{mg}$ & $98 \mathrm{mg}$ & $102 \mathrm{mg}$ \\
\hline FERRO TOTAL & $4.3 \mathrm{mg}$ & $8.2 \mathrm{mg}$ & $5.7 \mathrm{mg}$ & $5.5 \mathrm{mg}$ \\
\hline FERRO ANIMAL & $0.7 \mathrm{mg}$ & $4.7 \mathrm{mg}$ & $2.2 \mathrm{mg}$ & $2.0 \mathrm{mg}$ \\
\hline FOSFORO & $86 \mathrm{mg}$ & $261 \mathrm{mg}$ & $294 \mathrm{mg}$ & $285 \mathrm{mg}$ \\
\hline MAGNESIO & $98 \mathrm{mg}$ & $128 \mathrm{mg}$ & $144 \mathrm{mg}$ & $127 \mathrm{mg}$ \\
\hline POTASSIO & $996 \mathrm{mg}$ & $1331 \mathrm{mg}$ & $1266 \mathrm{mg}$ & $1266 \mathrm{mg}$ \\
\hline SODIO & $655 \mathrm{mg}$ & $702 \mathrm{mg}$ & $709 \mathrm{mg}$ & $709 \mathrm{mg}$ \\
\hline
\end{tabular}

